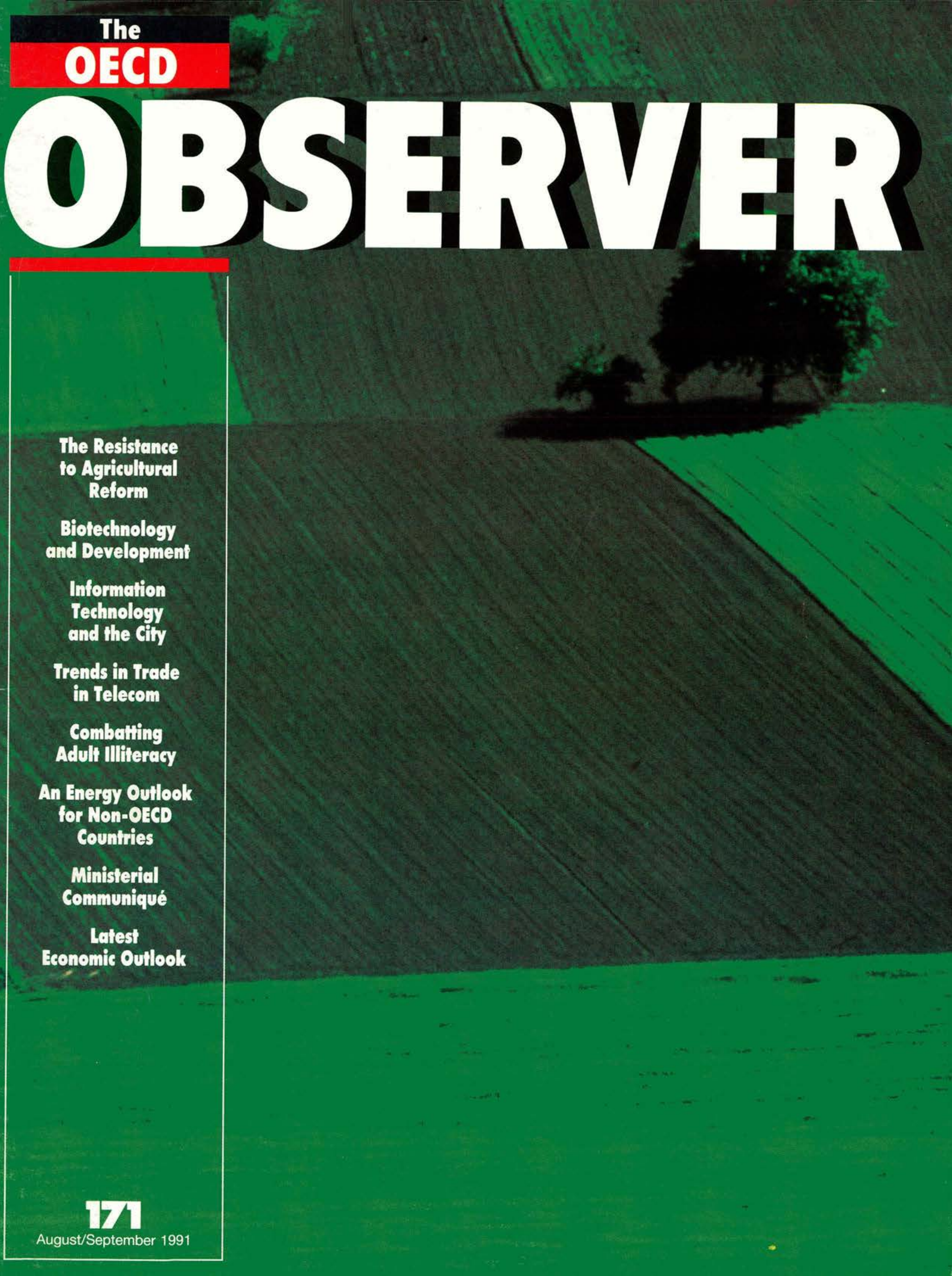




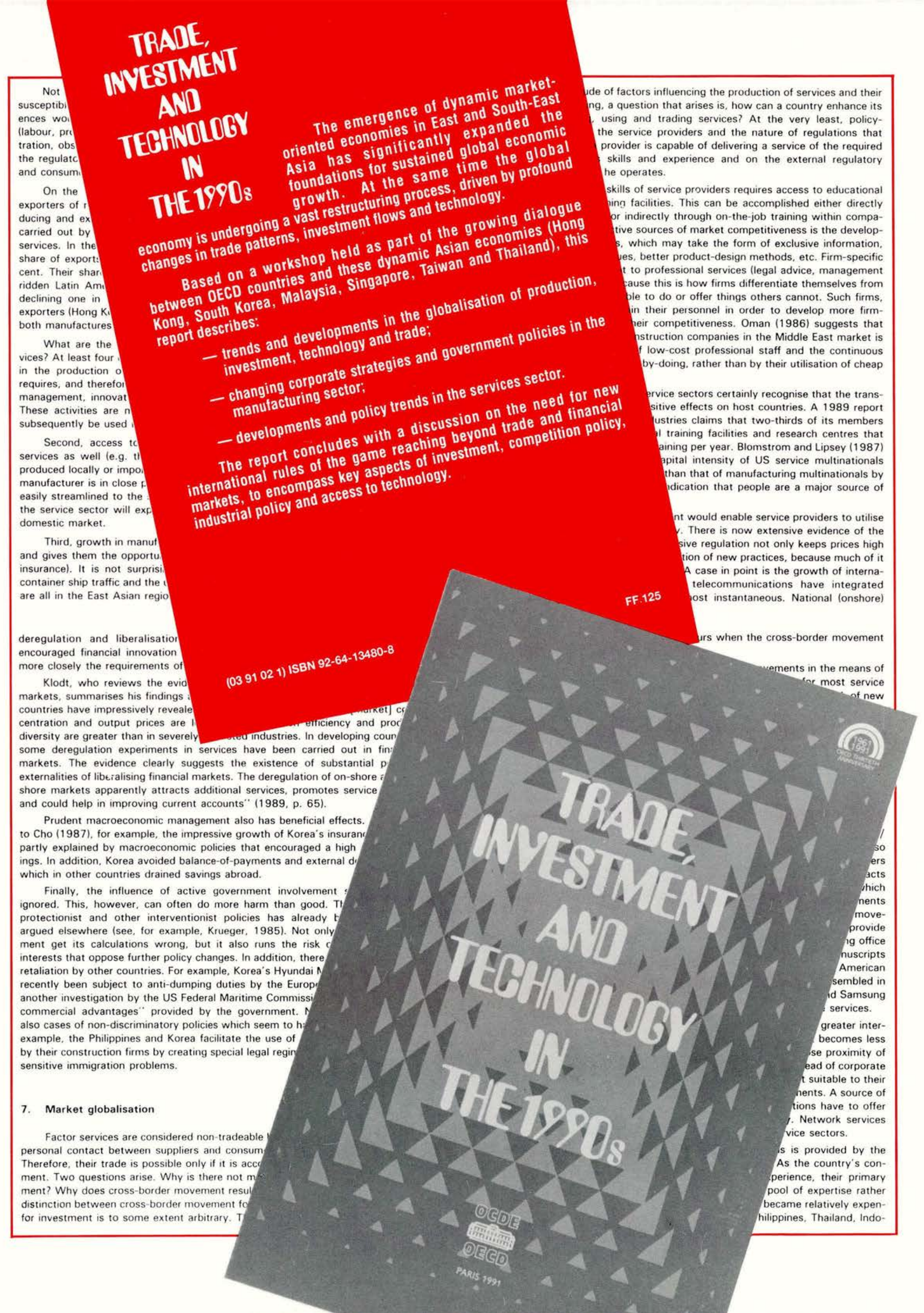




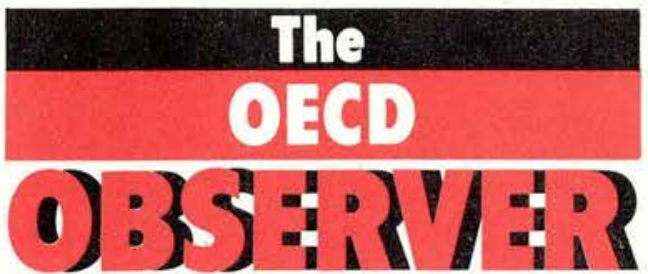

Published every two months in English and French by the ORGANISATION FOR ECONOMIC CO-OPERATION AND DEVELOPMENT.

Editorial Address:

OECD Publications Service

Château de la Muette

2. rue Andre-Pasca:

F 75775 PARIS CEDEX 16

Tel. (1) $45-24-82-00$

Fax (33-1) 45248500

Individual articles not copyrighted may be

reprinted, provided the credit line reads

'Reprinted from The OECD Observer' plus date

of issue and two voucher copies are sent to the Editor, with an indication of the circulation. Signed articles reprinted must bear the author's name.

Signed articles express the opinions of the authors and do not necessarily represent the opinion of the OECD.

The Organisation cannot be responsible for returning unsolicited manuscripts.

All the correspondence should be addressed to the Editor

Single copies

$£ 2.50$ US $\$ 4.50 \quad$ FF20.00 DM8.00

Annual Subscription Rates

$\begin{array}{llll}\mathbf{1 1 1 . 7 0} \text { US } \$ 22.00 & \text { FF100.00 D } 43.00\end{array}$

Tel. (1) 45-24-81-66

Editor

Ulla Ranhall-Reyners

Associate Editor

Martin Anderson

Assistant

Yannick Bultynck

Art, Production and Layout

Gérald Tingaud

Photo Research

Silvia Thompson-Lépot

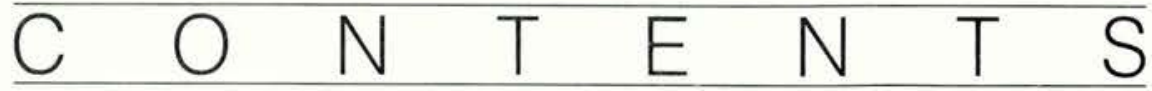

\section{agriculture}

\section{4}

THE RESISTANCE TO AGRICULTURAL REFORM

Gérard Viatte and Carmel Cahill

9

BIOTECHNOLOGY AND THE DEVELOPING WORLD: LESSONS FROM MAIZE

Carliene Brenner

13
INFORMATION TECHNOLOGY AND THE FUTURE OF THE CITY
Rémy Prud'homme
telecommunications
18
TRENDS IN TRADE IN TELECOM
Amy Plantin and Dimitri Ypsilanti
education
$\mathbf{2 1}$
COMBATTING ADULT ILLITERACY
Donald Hirsch
energy

25

AN ENERGY OUTLOOK FOR NON-OECD COUNTRIES

Mark Openshaw

economy

SPOTLIGHT ON :

29

GERMANY

Paul S. O'Brien and Niels Westerlund

32

FRANCE

Peter Jarrett and Marie-Odile Louppe

\section{3}

NEW OECD PUBLICATIONS

centrefold

ministerial communiqué

economic outlook

\section{1}

August/September 1991

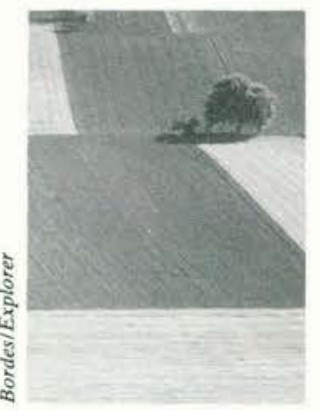

Agricultural producers in many OECD countries have been wrapped in a protective cocoon of high, even rising, prices with little or no exposure to underlying market signals. 


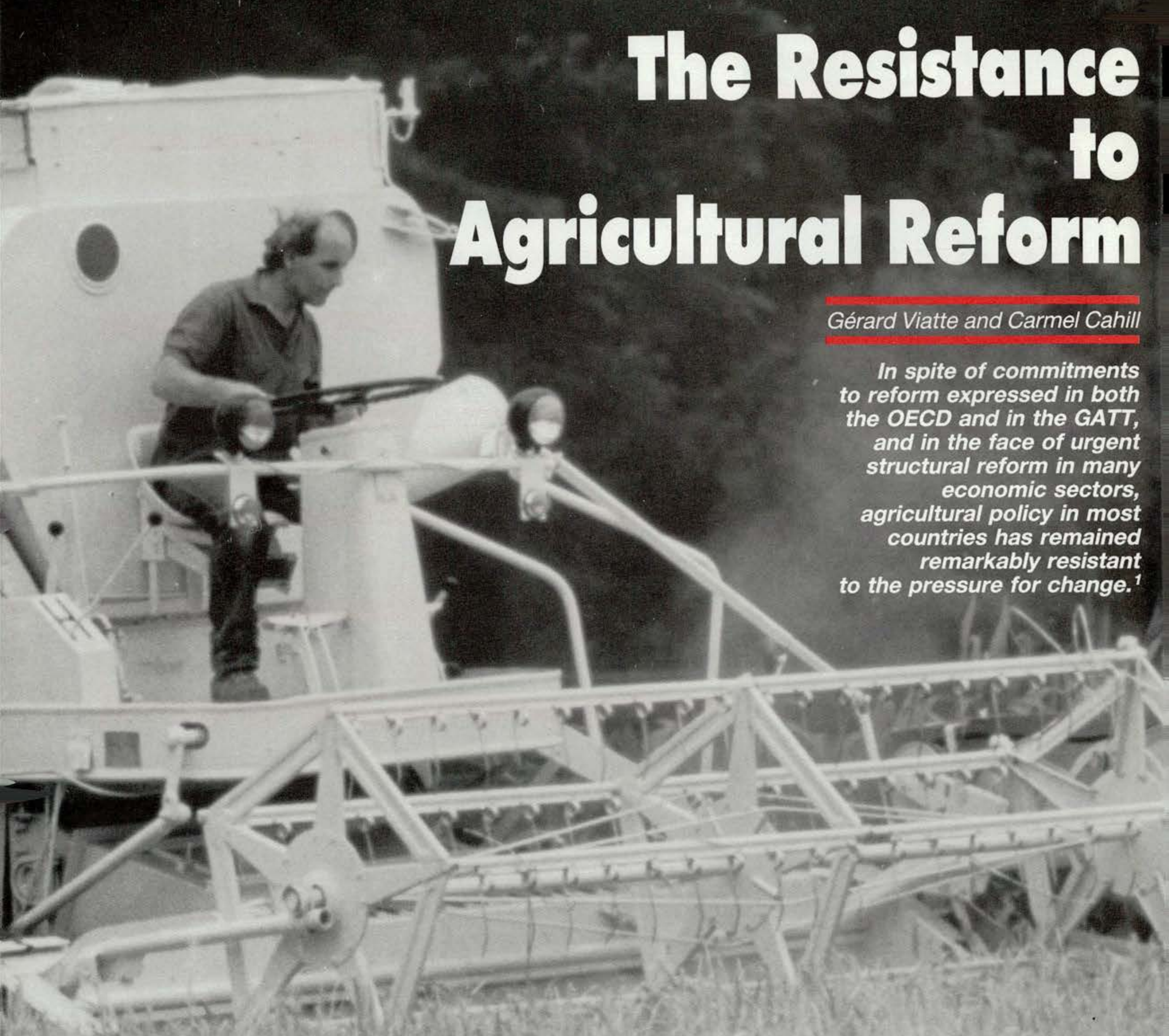


he agricultural policies implemented in the member countries of the OECD involve very high costs, generating total transfers from consumers and taxpayers of around US $\$ 300$ billion, according to the most recent estimate for 1990.

These transfers arise in a number of ways but principally because artificially high prices are set behind import barriers which prevent consumers obtaining lowerpriced agricultural commodities. Taxpayers also contribute by financing the export subsidies necessary to dispose of the excess production generated by high support prices. And they pay for a plethora of other aids as well, varying from deficiency payments to the provision of soft credit to farmers or the financing of research and extension activities.

The overall result is that agricultural producers in many OECD countries have been wrapped in a protective cocoon of high, even rising, prices with little or no exposure to underlying market signals. This has had a detrimental effect on a number of other countries which are efficient lowcost producers of agricultural commodities but which are either unwilling or unable to subsidise their agricultural producers. The agricultural sectors in these countries suffer the vagaries and volatility of world markets in which prices are often extremely low, and fluctuate widely, frequently as a result of the subsidising activity of the countries where assistance is high.

In Paris in 1987, prompted by concerns about trade tensions and the economic cost of agricultural assistance and protection, OECD Ministers undertook to implement a reform of agricultural policy. The result was to be lower assistance, a bigger role for market signals in guiding production and consumption, and a more liberal trading environment for agriculture. The balance sheet for those objectives established in Agricultural Policies, Markets and Trade: Monitoring and Outlook 1991 is not encouraging.

1. Agricultural Policies, Markets and Trade: Monitoring and Outlook 1991, OECD Publications, Paris, 1991.

Gerard Viatte is Director of the OECD Food, Agriculture and Fisheries Directorate, where, until recently. Carmel Cahill was an economist in the Policies Division.

\section{Table \\ PRODUCER SUBSIDY EQUIVALENTS}

all products by country

\begin{tabular}{|c|c|c|c|c|c|c|}
\hline & Units & $\begin{array}{c}1979-86 \\
\text { (average) }\end{array}$ & 1987 & 1988 & $\begin{array}{c}1989 \\
\text { (estimate) }\end{array}$ & $\begin{array}{c}1990 \\
\text { (provisional) }\end{array}$ \\
\hline $\begin{array}{l}\text { AUSTRALIA } \\
\text { Net total PSE } \\
\text { Net total PSE } \\
\text { Net percentage PSE }\end{array}$ & $\begin{array}{l}\text { A } \$ \text { bn } \\
\text { US\$ bn } \\
\%\end{array}$ & $\begin{array}{r}1.20 \\
1.07 \\
12 \\
\end{array}$ & $\begin{array}{r}1.58 \\
1.10 \\
11\end{array}$ & $\begin{array}{r}1.58 \\
1.23 \\
9\end{array}$ & $\begin{array}{r}1.58 \\
1.25 \\
10\end{array}$ & $\begin{array}{r}1.66 \\
1.30 \\
11\end{array}$ \\
\hline $\begin{array}{l}\text { AUSTRIA } \\
\text { Net total PSE } \\
\text { Net total PSE } \\
\text { Net percentage PSE }\end{array}$ & $\begin{array}{c}\text { Sch bn } \\
\text { US\$ bn } \\
\%\end{array}$ & $\begin{array}{r}17.71 \\
1.07 \\
32 \\
\end{array}$ & $\begin{array}{r}27.75 \\
2.19 \\
48\end{array}$ & $\begin{array}{r}26.72 \\
2.16 \\
47 \\
\end{array}$ & $\begin{array}{r}22.63 \\
1.71 \\
39 \\
\end{array}$ & $\begin{array}{r}26.92 \\
2.37 \\
46 \\
\end{array}$ \\
\hline $\begin{array}{l}\text { CANADA } \\
\text { Net total PSE } \\
\text { Net total PSE } \\
\text { Net percentage PSE }\end{array}$ & $\begin{array}{l}C \$ b n \\
\text { US\$bn } \\
\%\end{array}$ & $\begin{array}{r}5.35 \\
4.19 \\
32 \\
\end{array}$ & $\begin{array}{r}8.84 \\
6.66 \\
49 \\
\end{array}$ & $\begin{array}{r}7.54 \\
6.12 \\
42 \\
\end{array}$ & $\begin{array}{r}6.58 \\
5.56 \\
37 \\
\end{array}$ & $\begin{array}{r}7.54 \\
6.46 \\
41 \\
\end{array}$ \\
\hline $\begin{array}{l}\text { EUROPEAN COMMUNITY }{ }^{2} \\
\text { Net total PSE } \\
\text { Net total PSE } \\
\text { Net percentage PSE }\end{array}$ & $\begin{array}{c}\text { ECU bn } \\
\text { US\$ bn } \\
\%\end{array}$ & $\begin{array}{r}39.58 \\
39.87 \\
37 \\
\end{array}$ & $\begin{array}{r}63.22 \\
72.95 \\
49 \\
\end{array}$ & $\begin{array}{r}59.64 \\
70.48 \\
46 \\
\end{array}$ & $\begin{array}{r}55.85 \\
61.49 \\
41 \\
\end{array}$ & $\begin{array}{r}64.29 \\
81.62 \\
48 \\
\end{array}$ \\
\hline $\begin{array}{l}\text { FINLAND } \\
\text { Net total PSE } \\
\text { Net total PSE } \\
\text { Net percentage PSE }\end{array}$ & $\begin{array}{l}\text { Mkbn } \\
\text { US\$bn } \\
\%\end{array}$ & $\begin{array}{r}11.28 \\
2.25 \\
58 \\
\end{array}$ & $\begin{array}{r}16.57 \\
3.77 \\
72 \\
\end{array}$ & $\begin{array}{r}17.01 \\
4.06 \\
73 \\
\end{array}$ & $\begin{array}{r}18.25 \\
4.26 \\
70 \\
\end{array}$ & $\begin{array}{r}20.33 \\
5.32 \\
72 \\
\end{array}$ \\
\hline $\begin{array}{l}\text { JAPAN } \\
\text { Net total PSE } \\
\text { Net total PSE } \\
\text { Net percentage PSE }\end{array}$ & $\begin{array}{l}\text { Y tr } \\
\text { US\$bn } \\
\%\end{array}$ & $\begin{array}{r}4.74 \\
21.56 \\
66\end{array}$ & $\begin{array}{r}5.08 \\
35.15 \\
76\end{array}$ & $\begin{array}{r}4.68 \\
36.52 \\
74\end{array}$ & $\begin{array}{r}4.65 \\
33.67 \\
71\end{array}$ & $\begin{array}{r}4.47 \\
30.86 \\
68\end{array}$ \\
\hline $\begin{array}{l}\text { NEW ZEALAND } \\
\text { Net total PSE } \\
\text { Net total PSE } \\
\text { Net percentage PSE }\end{array}$ & $\begin{array}{c}\text { NZ\$ bn } \\
\text { US\$bn } \\
\%\end{array}$ & $\begin{array}{r}1.02 \\
0.74 \\
25 \\
\end{array}$ & $\begin{array}{r}0.65 \\
0.34 \\
14 \\
\end{array}$ & $\begin{array}{r}0.39 \\
0.24 \\
7\end{array}$ & $\begin{array}{r}0.33 \\
0.21 \\
5\end{array}$ & $\begin{array}{r}0.29 \\
0.17 \\
5\end{array}$ \\
\hline $\begin{array}{l}\text { NORWAY } \\
\text { Net total PSE } \\
\text { Net total PSE } \\
\text { Net percentage PSE }\end{array}$ & $\begin{array}{c}\text { NKrbn } \\
\text { US\$bn } \\
\%\end{array}$ & $\begin{array}{r}11.48 \\
1.71 \\
72 \\
\end{array}$ & $\begin{array}{r}17.04 \\
2.53 \\
76\end{array}$ & $\begin{array}{r}17.36 \\
2.66 \\
76 \\
\end{array}$ & $\begin{array}{r}17.62 \\
2.55 \\
75 \\
\end{array}$ & $\begin{array}{r}19.57 \\
3.13 \\
77 \\
\end{array}$ \\
\hline $\begin{array}{l}\text { SWEDEN } \\
\text { Net total PSE } \\
\text { Net total PSE } \\
\text { Net percentage PSE }\end{array}$ & $\begin{array}{c}\text { SKrbn } \\
\text { US\$bn } \\
\%\end{array}$ & $\begin{array}{r}10.61 \\
1.64 \\
44 \\
\end{array}$ & $\begin{array}{r}15.76 \\
2.53 \\
57 \\
\end{array}$ & $\begin{array}{r}15.39 \\
2.45 \\
52 \\
\end{array}$ & $\begin{array}{r}16.79 \\
2.72 \\
52 \\
\end{array}$ & $\begin{array}{r}19.32 \\
3.38 \\
59 \\
\end{array}$ \\
\hline $\begin{array}{l}\text { SWITZERLAND } \\
\text { Net total PSE } \\
\text { Net total PSE } \\
\text { Net percentage PSE } \\
\end{array}$ & $\begin{array}{l}\text { SF bn } \\
\text { US\$bn } \\
\%\end{array}$ & $\begin{array}{r}5.22 \\
2.62 \\
68 \\
\end{array}$ & $\begin{array}{r}6.66 \\
4.47 \\
80 \\
\end{array}$ & $\begin{array}{r}6.97 \\
4.76 \\
78 \\
\end{array}$ & $\begin{array}{r}6.83 \\
4.18 \\
73 \\
\end{array}$ & $\begin{array}{r}6.95 \\
5.00 \\
78 \\
\end{array}$ \\
\hline $\begin{array}{l}\text { UNITED STATES } \\
\text { Net total PSE } \\
\text { Net percentage PSE }\end{array}$ & $\begin{array}{c}\text { US\$bn } \\
\%\end{array}$ & $\begin{array}{r}30.66 \\
28 \\
\end{array}$ & $\begin{array}{r}45.07 \\
41 \\
\end{array}$ & $\begin{array}{r}37.21 \\
34 \\
\end{array}$ & $\begin{array}{r}33.42 \\
29 \\
\end{array}$ & $\begin{array}{r}35.93 \\
30 \\
\end{array}$ \\
\hline $\begin{array}{l}\text { OECD } \\
\text { Net total PSE } \\
\text { Net percentage PSE }\end{array}$ & $\begin{array}{c}\text { US\$ bn } \\
\%\end{array}$ & $\begin{array}{r}07.38 \\
37\end{array}$ & $\begin{array}{r}176.78 \\
50\end{array}$ & $\begin{array}{r}167.91 \\
46\end{array}$ & $\begin{array}{r}151.01 \\
41\end{array}$ & $\begin{array}{r}175.54 \\
44\end{array}$ \\
\hline
\end{tabular}

1. The average percentage PSEs for $1979-86$ have been weighted by the value of production for each commodity. 2. EC: EC-10 1979-85, EC-12 1986-90.

Source: $\mathrm{OECD}$

Assistance, as measured by the Producer Subsidy Equivalents (PSEs), rose sharply in 1990 and is now close to the historic peak reached in 1987 (Table). This increase followed two years of decline in 1988 and 1989 , because of drought which pushed up world prices and cut supplies in some parts of the world, or because of supply control measures which had the same effect. These events provided a temporary alleviation; policy-makers were lulled into a false sense of security by this 
sudden tightening in the balance between supply and demand and the resulting rise in prices. But the breathing space was short-lived, and in 1990 the situation was completely reversed, with the re-emergence of structural surpluses aggravated by sharp falls in demand caused by a succession of factors (including economic reform, leading to the removal of food subsidies in central and eastern Europe, and the Gulf crisis). The resulting declines in world prices were in turn compounded by the weakness of the US dollar, so that the gap between internal and external prices widened considerably.

If reform efforts to date had been more successful, they would not have left intact the border mechanisms which prevent the transmission of market signals from world to domestic markets, and assistance in 1990 could not have risen as it did. Moreover, projections for 1991 suggest that unless policies are changed in the direction of reform, assistance as measured by the PSE will rise once more.

\section{Litile Improvement}

With overall assistance still equal to historic peaks four years into the reform process, is it possible to point to any beneficial developments? New Zealand is one country which has implemented a comprehensive reform, resulting in an agricultural sector whose economic fortunes are derived almost entirely from the international market-place and where assistance is extremely low. Australia also has made a substantial effort, dismantling or adjusting some support mechanisms, and here too, assistance to agriculture is low. Measured by the PSE, and expressed in terms of a percentage of the value of output, assistance in 1990 was 5 and $11 \%$ in New Zealand and Australia respectively; these are the two countries with the lowest degrees of support amongst all the OECD member countries. Of course, farm incomes in these countries have come under severe pressure in recent months as world prices have plummeted for a number of important commodities, while farmers in many other countries are cushioned from the price movements by import barriers and export subsidies.

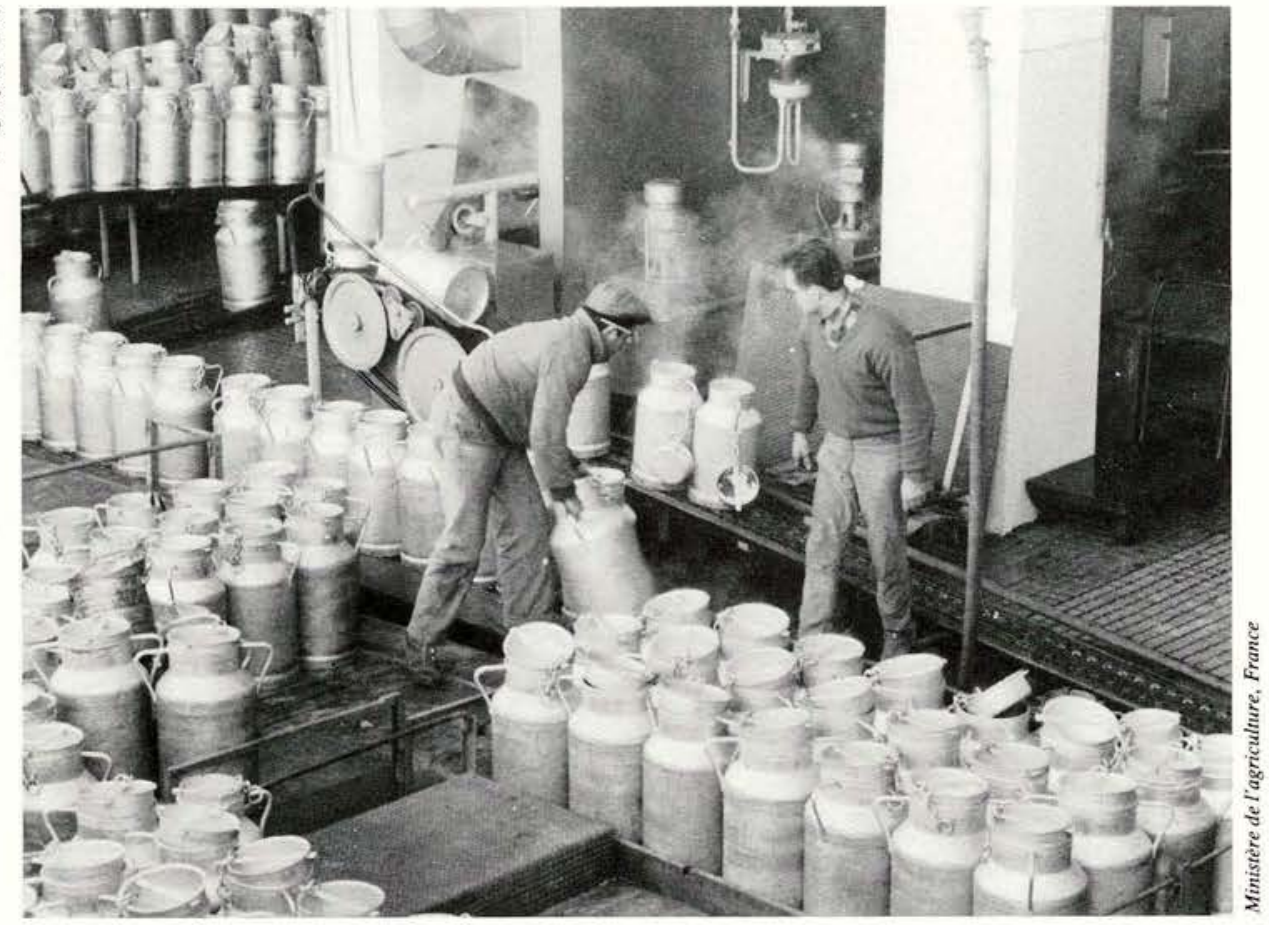

The only other country whose PSE, as estimated for 1990 , is significantly below the OECD average of $44 \%$ is the United States, with $30 \%$. Towards the end of 1990, the United States enacted a comprehensive new farm bill which has set the main lines of agricultural policy for the next five years. The 'flexibility' provision contained in the new legislation allows farmers much wider choice in their decisions on crop planting, while also reducing deficiency payment eligibility by $15 \%$, and it involves a significant step in the direction of more exposure to market sig-

\section{WHICH COMMODITIES RECEIVE THE MOST SUPPORT?}

In terms of the percentage PSE, rice is the most highly assisted commodity in OECD countries. This figure reflects mainly the situation in Japan where rice is both a very important commodity and is highly assisted and protected. In absolute value the milk PSE ( $\$ 58$ billion in 1990) overshadows all others, reflecting the size of the dairy sector in most OECD countries and the very high degree of assistance. In percentage terms, the milk PSEs of most countries are in excess of $60 \%$ (the OECD average in 1990 was $68 \%$ ), and in general the highest PSEs occur in countries which control supply. Mutton and lamb and sugar follow in the ranking of the most highly assisted commodities in percentage terms; beef and veal follow milk in absolute terms. Other commodities which contribute significantly to the overall average PSEs - in both percentage and absolute terms - are wheat and coarse grains. Throughout the OECD the lowest degrees of assistance are found for pigmeat, poultry and eggs. nals. But this change is limited to some crops, and other provisions of the new US legislation seem unlikely to reduce assistance or improve exposure to market signals, while the increased complexity in US policy generally has led to a loss of transparency.

All the other OECD countries have PSES around or far in excess of the OECD average of $44 \%$. Those coming close to it include Austria, Canada and the EC, while another group, not least Finland, Japan, Norway and Switzerland, have PSEs which fall between one-and-a-half times and twice the OECD average. But even among the countries with higher-than-average PSEs, there are some encouraging signs for the future. Sweden has announced a sweeping reform programme, to be implemented in 1991, which envisages the abolition of export subsidies, of administered pricing and of domestic market regulation. Japan is replacing import quotas with tariffs in a number of sectors, the most important of which is beef; these tariffs, although initially high, are scheduled to be reduced gradually. Notwithstanding the maintenance of high protective barriers in other sectors, this move by Japan is important because it indicates a willingness to replace a highly insulating policyinstrument - a quota - by a tariff which creates the potential for increasing exposure to market signals.

\section{An Assessment of Policy}

But on the whole there is a hard core of are very few other examples of the kind of change in policy mechanisms which would resistance to radical change, and there 
be required to achieve real reform. In evaluating changes and developments in the light of the principles and guidelines laid down by Ministers in 1987, the 1991 Monitoring Report comes to a series of conclusions.

First, progress in the direction of increased market orientation was again very limited in 1990: support prices were frozen or increased in most countries, although the OECD average of prices paid to producers fell marginally.

Second, confirming the rather gloomy assessment on market orientation, little progress has been reported in the related area of trade measures. Again, very few countries have liberalised imports, and some have tightened already existing restrictions. In exports, falling world prices and growth in supplies have led to increased assistance in many countries.

... while in percentage terms it is rice that has most assistance in the OECD countries.

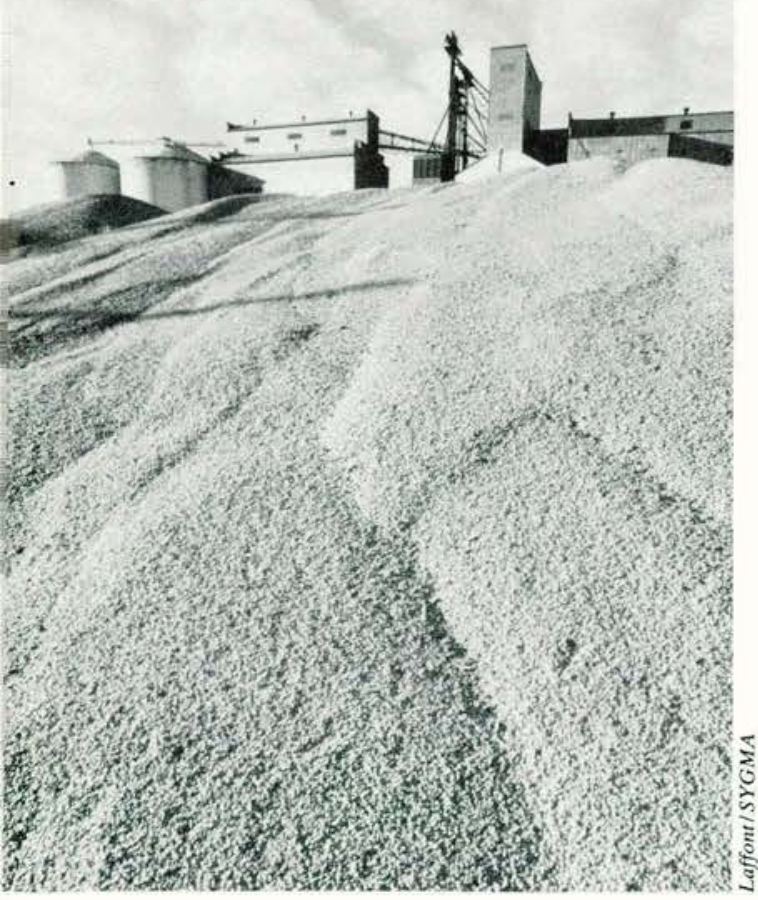

Third, supply controls continued in most countries that offer high and growing assistance, in many cases leading to almost total insulation of the sectors concerned from market signals and to severe economic distortions. Very few measures have been taken in the current period of review to redress these difficulties, despite the agreement expressed in various ministerial communiqués. Moreover, falls in demand in 1990 (affecting mainly dairy products) put in question the ability of rigid controls on supply to improve market balances beyond the immediate effect of limiting production to specified volumes.

\section{THE URUGUAY ROUND}

The central feature of the agricultural element of the Uruguay Round of international trade negotiations is the inclusion of domestic policies. It has been recognised that domestic price and income supports lie at the root of trade tensions and problems. Nonetheless, agriculture has proved to be one of the more contentious issues. Failure to agree on agriculture was one of the reasons that the Mid-Term Review of the Round held in Montreal in December 1988 was not concluded, although a framework agreement was reached subsequently. Agriculture again became a major stumbling block at the Brussels meeting held in December 1990 which was scheduled to bring the Uruguay Round to a close. This meeting also failed to arrive at a global agreement. All parties have now agreed to conduct negotiations to achieve specific binding commitments on domestic support, market access, and export competition, and to reach an agreement on sanitary and phytosanitary issues. Technical consultations have begun again.

Fourth, no measures have been identified which significantly improved demand either inside or outside the OECD; indeed, it is clear that persistent high domestic prices in most countries have dampened it.

Fifth, some progress can be reported in direct income payments. ${ }^{2} \mathrm{~A}$ few countries have implemented new measures, or adjusted existing ones, to weaken the link between income support and production. One disquieting feature is that they have not generally been taken in a context of reduced overall assistance. In some instances they have actually increased

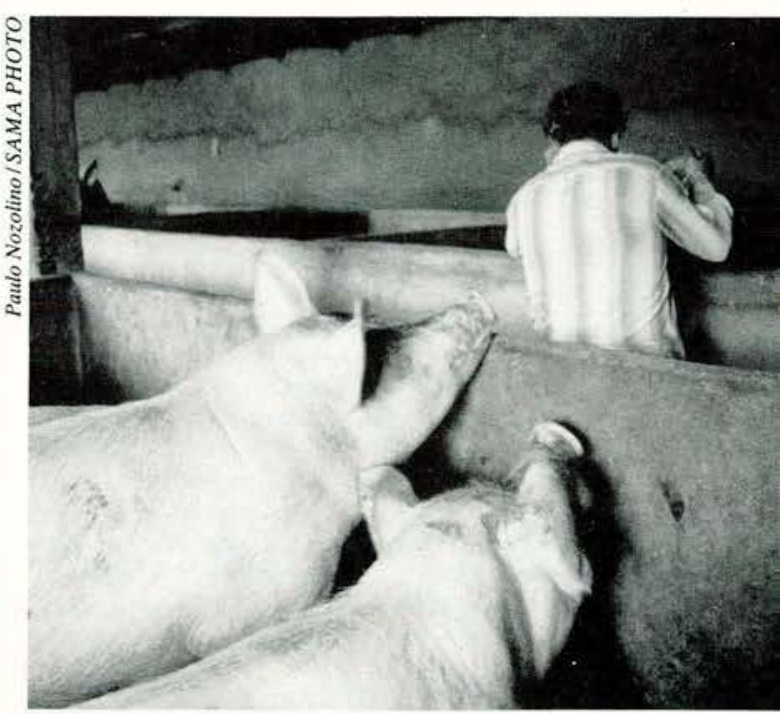

For pigmeat, poultry and eggs support is relatively low.

assistance, although in the context of a transition to a more market-oriented system.

Sixth, some progress has been made in environmental policies, although here also there is a risk that insufficient attention to the design of policies may lead to instruments that are not economically efficient.

Last, interest is growing in rural development, particularly in the context of a response to the consequences of agricultural policy reform, and may eventually help to underpin that process. ${ }^{3}$

\section{The Urgency of Reform}

There has been a tendency in the past for farmers and even for agricultural policymakers to look to demand to absorb excess supply. But the solution is unlikely to be found there. Medium-term projections established by the OECD suggest that if current policies persist, growth in production will outstrip growth in demand up to 1995 , exacerbating the problem of disposing of excess supply for virtually all

2. See Wilfred Legg, 'Direct Income Support', The OECD Observer, No. 168, February/March 1991.

3. See Christian Huillet and Pieter van Dijk, 'New Policies for the Countryside', The OECD Observer, No. 150 , February/March 1988 , and Christian Huillet and Pieter van Dijk, 'Partnerships for Rural Development', The OECD Observer, No. 162, February/ March 1990. 


\section{WHAT OF THE CONSUMER?}

Although policy-makers often focus on the budget, the lion's share of the transfers to producers generated by agricultural policy is paid, through higher prices, by consumers. These transfers have been measured using the Consumer Subsidy Equivalent (CSE) which is defined as the implicit tax imposed on consumers (through artificially high prices) net of other transfers (such as subsidies). These transfers rose sharply in the OECD area in 1990 to over $\$ 133$ billion $(36 \%)$, a figure which, like the PSE, is close to the historic peak reached in 1987. As transfers to producers from consumers are exacted through higher prices, they have a dampening effect on demand which in turn exacerbates the problem of disposing of the excess supply.

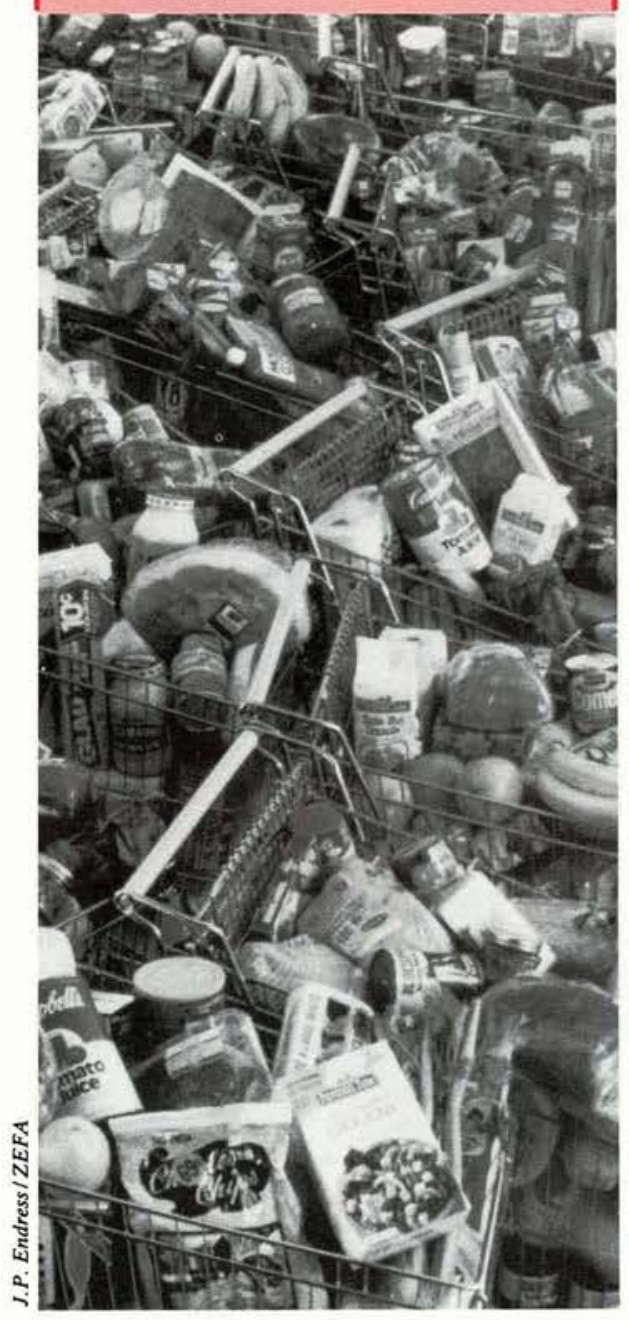

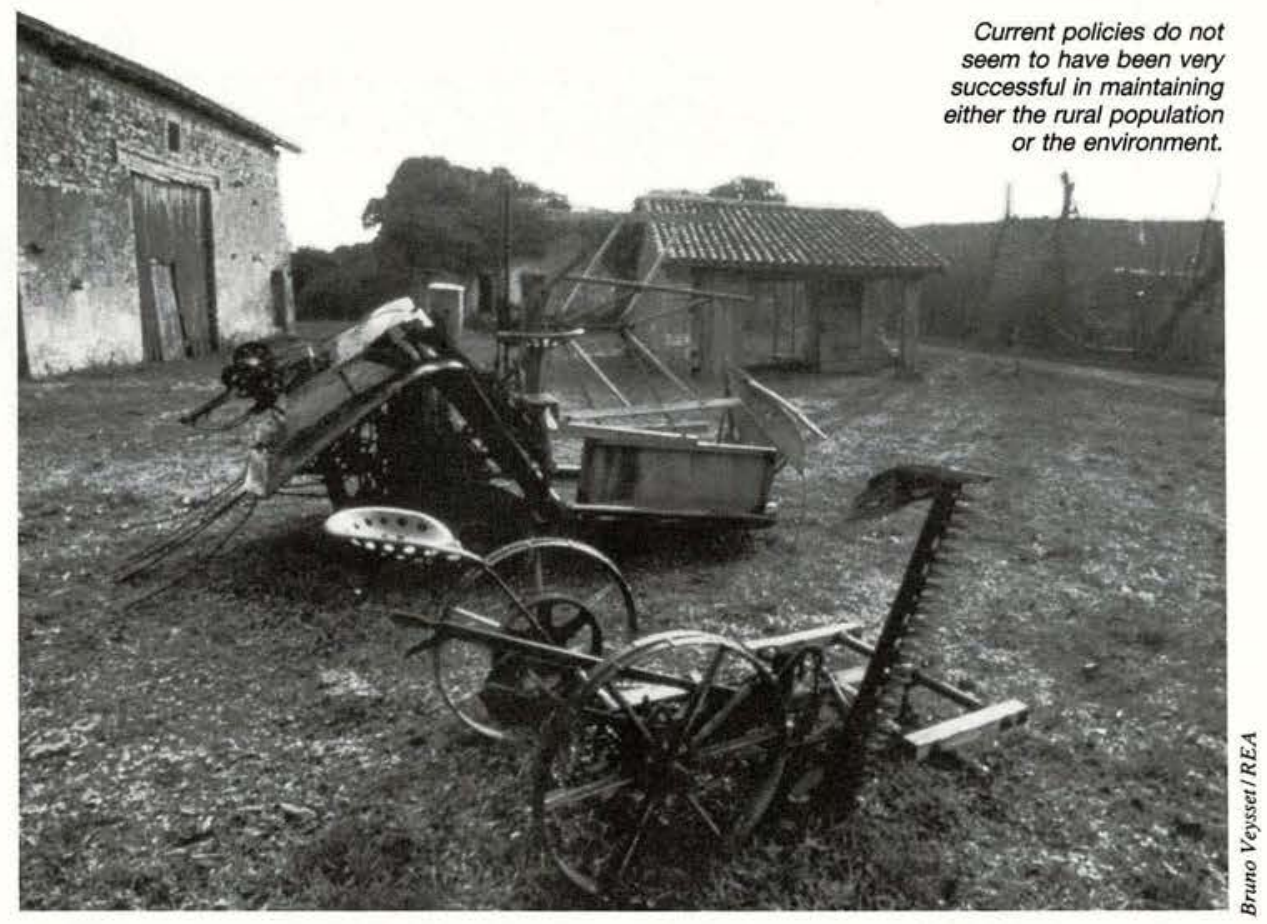

major temperate commodities. These difficulties will be particularly marked in coarse grains and beef but will also be substantial for wheat and dairy products.

The best avenue to increased demand would be, quite simply, a policy reform that increased the role of market signals in determining consumption. Particularly for livestock products, the lower prices likely to result could generate significantly improved demand. But to date little progress has been made in this direction.

Budget pressures are already severe in some countries and will not allow everincreasing production to be disposed of on world markets at bargain prices. The solution lies in a fundamental reform of agricultural policies in the direction indicated by OECD Ministers in 1987. A successful outcome to the Uruguay Round of international trade negotiations, which in agriculture encompasses domestic as well as trade policy, is essential.

But reform does not imply the abandonment of agricultural policy objectives in farm incomes, the maintenance of the rural population or the environment. In any event, current policies would not seem to have been very successful in meeting these objectives: large numbers of producers have continued to leave agriculture and are not replaced, and the regressive nature of output-based policies has meant that the largest producers have been the largest beneficiaries. Agricultural policy objectives should rather be met through policy instruments that are less costly and less distorting.

The OECD has already begun to study these questions, concentrating on the issue of direct income payments as an alternative to output- or input-related policies, and is currently extending this work to examine questions involving the environment and the provision of leisure and amenity services by the farming sector.

The maintenance of highly subsidised and protected sectors lowers the overall efficiency of an economy. Structural reform OECD and other economies can become stronger and more efficient - and thus emerge more quickly from the present downturn. And in agriculture that process has barely begun.

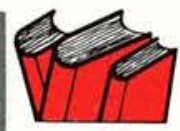

\section{OECD Bibliography}

- Agricultural Policies, Marikets and Trade: Monitoring and Outlook 1991, 1991

- Wilfred Legg, 'Direct Income

Support', The OECD Observer,

No. 168, February/March 1991

- Carmel Cahill, 'Quantitative

Restrictions on Output', The OECD 1991

- Reforming Agricultural Policies:

Quantitative Restrictions on

Production. Direct Income Support, 1990

- Christian Huillet and Pieter van Dijk, 'Partnerships for Rural Development',

The OECD Observer, No. 162,

February/March 1990

- OECD Economic Studies, No. 13,

Winter 1989-1990

- Gérard Viatte and Frédéric Langer,

'Agricultural Reform: A Hesitant Start',

The OECD Observer, No. 165,

August/September 1990

- Christian Huillet and Pieter van Dijk,

'New Policies for the Countryside',

The OECD Observer, No. 150,

February/March 1988. is imperative as a means whereby the

Observer, No. 168, February/March 


\section{Biolechnology \\ in the Developing World}

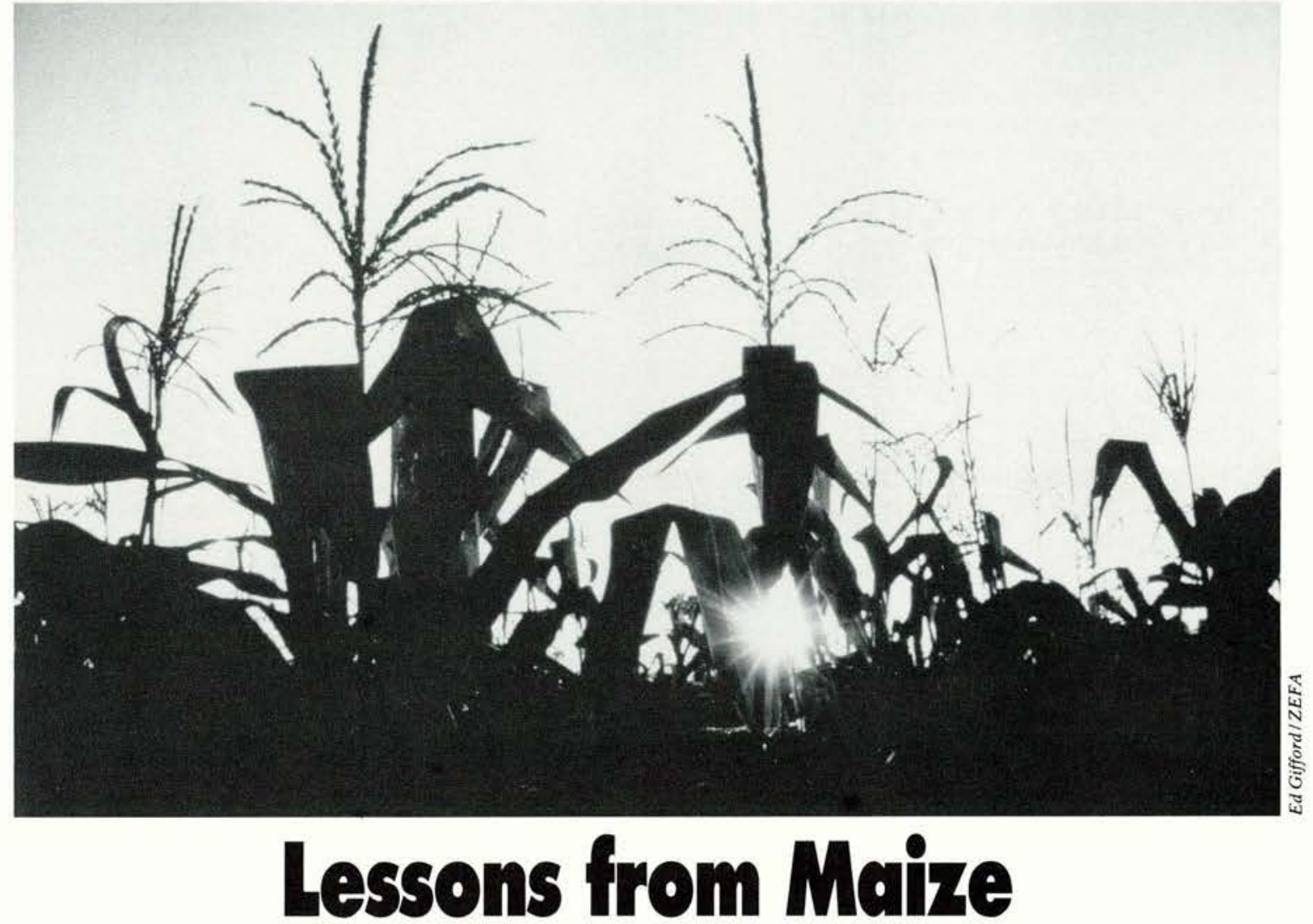

Carliene Brenner

The early promise of plant biotechnology has not yet materialised. And evidence from the developing world suggests that the barriers are economic and institutional as well as technical. ${ }^{1}$

$\mathrm{n}$ spite of the very large sums invested in biotechnology research, extravagant claims of impending innovations and, indeed, the optimism of earlier expectations, few products resulting from new biotechnologies - other than in human and animal health care - have yet reached the market. The first major wave of products based on plant biotechnology is now expected to occur between 1995 and the turn of the century. These include plant diagnostics, microbial insecticides, tissue culture and micropropagation techniques, genetic mapping techniques, and transgenic plants resistant to specific herbicides, viruses and insects.

Most biotechnology R\&D is concentrated in the OECD countries. Yet it is in the developing world, where growing populations require an increase in both the volume and quality of agricultural production, that the pressure for technological innovation is most keenly felt. But can these countries take advantage of the new techniques in their crop production systems? Can they develop and disseminate biotechnologies of their own? And could this process be facilitated by the international transfer of technology?

Maize is one of the world's major cereal crops, accounting for around a quarter of total cereals production. It is also an essential food and/or feed crop in Carliene Brenner is a member of the research staff in the OECD Development Centre. many developing countries. In the 1930s, research resulted in a major technological innovation - the first appearance of hybrid varieties. ${ }^{2}$ Since then maize has been the object of continuous research efforts and will probably be one of the first cereal grains to incorporate new biotechnologies (for example, with resistance to particular pests or herbicides). Demand for maize, moreover, particularly for livestock feed,

1. Biotechnology and Developing Country Agriculture: The Case of Maize, Development Centre/ OECD Publications, Paris, 1991.

2. Hybrids, unlike open-pollinated varieties, do not transmit improved genetic or other properties to progeny and therefore provide patent-like protection. Hybrid seed replanted a second year will give much reduced yields and so producers are induced to purchase new seed for each successive planting. 
has been expanding in developing countries, often outstripping domestic supply, and is forecast to continue expanding in the medium term.

So biotechnological advance in maize could have far-reaching implications in the lives of many millions of people. But an examination of four developing countries Brazil, Indonesia, Mexico and Thailand reveals that the prospects for stepping up the supply of maize through the introduction of new maize biotechnologies are far from certain. most important cereal crop, or second most important after rice, in terms of the area planted and volume of production (Table). Although production conditions vary considerably from one region and country to another, maize is generally grown on small-holdings, with low volumes of chemical inputs, on rainfed rather than irrigated land. The share of hybrids is increasing, yet unimproved local varieties (seed saved by farmers from previous plantings) still account for more than two-
In these four countries, maize is the

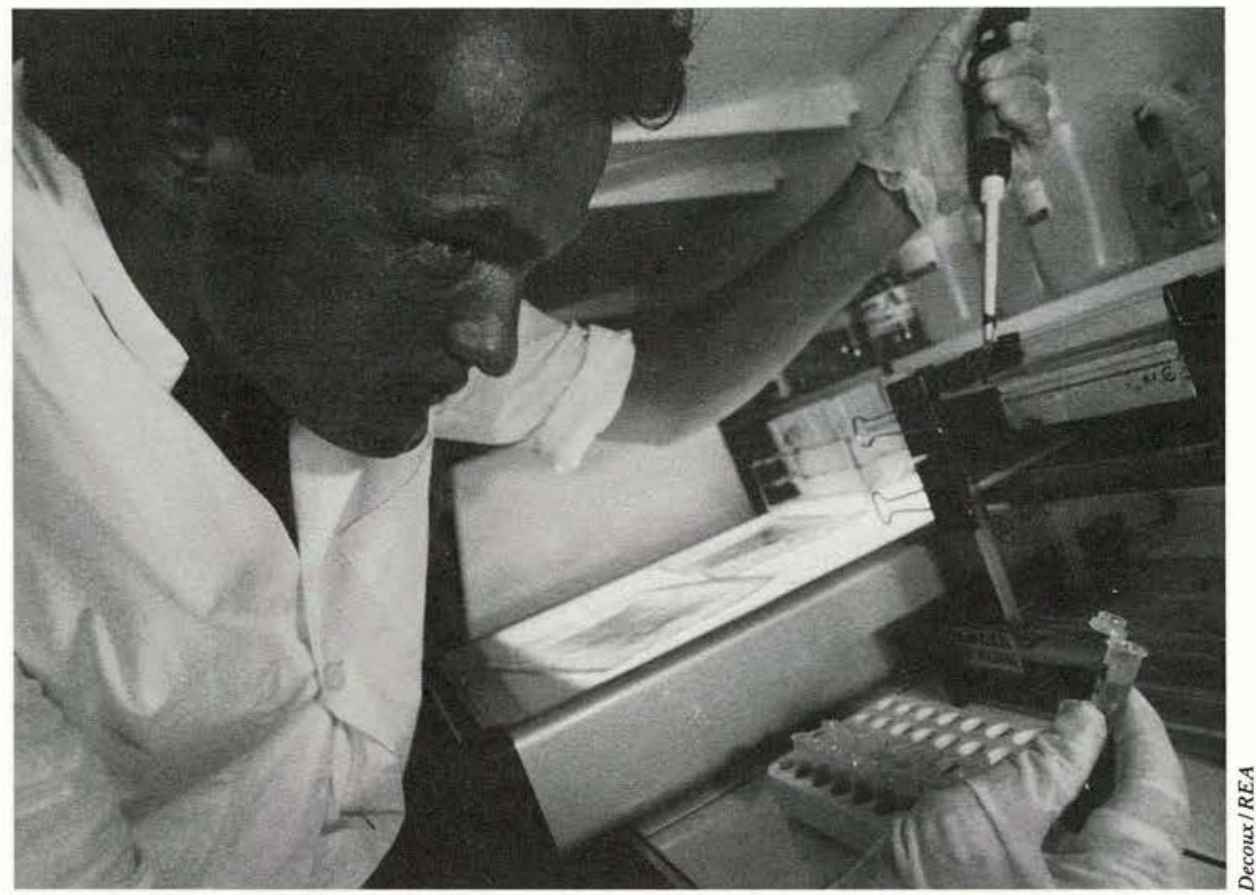

thirds of the total area cultivated in Indonesia and Mexico. These open-pollinated varieties account for an overwhelming share of cultivation in Thailand. Only in Brazil do hybrids account for more than half the total area planted.

Little new land is available for maize cultivation in these countries. So if they are to meet fast-growing demand, even partially, through increased domestic production, they will have to produce new, genetically improved varieties and high-quality seed. Such progress requires, at the very least,

\begin{tabular}{|c|c|c|c|c|c|}
\hline \multicolumn{6}{|c|}{$\begin{array}{l}\text { Table } \\
\text { COMPARATIVE DATA ON MAIZE }\end{array}$} \\
\hline & Brazil & Indonesia & Mexico & Thailand & $\begin{array}{l}\text { Developed } \\
\text { Market } \\
\text { Economies }\end{array}$ \\
\hline $\begin{array}{l}\text { Average annual production 1986-88 } \\
\text { million metric tons }\end{array}$ & 24 & 6 & 12 & 4.1 & \\
\hline $\begin{array}{l}\text { Annual average production } \\
\text { growth rate (\%) }\end{array}$ & 2.9 & 5.5 & 3.4 & 5.4 & 2.3 \\
\hline Ranking in terms of area planted & 1 & $2^{a}$ & 1 & $2^{a}$ & - \\
\hline $\begin{array}{l}\text { Average annual yields } \\
\text { tons/hectare }\end{array}$ & 1.8 & 2.0 & 1.7 & 2.4 & 6.2 \\
\hline $\begin{array}{l}\text { Growth rate of maize } \\
\text { utilisation per capita (\%) }\end{array}$ & 1.5 & 3.7 & 1.1 & 9.3 & 1.2 \\
\hline \multicolumn{6}{|l|}{$\begin{array}{l}\text { Share of total maize } \\
\text { consumption (\%) as: }\end{array}$} \\
\hline food & 14 & 92 & 80 & 12 & 40 \\
\hline feed & 75 & 2 & 9 & 77 & 50 \\
\hline other & 11 & 6 & 12 & 11 & 10 \\
\hline \multicolumn{6}{|l|}{$\begin{array}{l}\text { Type of seed planted } \\
\text { \% of total maize area }\end{array}$} \\
\hline unimproved local varieties & 30 & 70 & 74 & 1 & 1 \\
\hline open-pollinated varieties & 7 & 27 & 11 & 84 & - \\
\hline hybrids & 63 & 3 & 15 & 15 & 99 \\
\hline $\begin{array}{l}\text { Net imports per capita } \\
\mathrm{kg} / \mathrm{yr}\end{array}$ & 8 & 1 & 36 & -43 & -25 \\
\hline
\end{tabular}

a well co-ordinated system of basic and applied research in plant breeding, the efficient multiplication and production of seeds, the adequate testing and certification of seed quality, and marketing.

\section{Achievements and Obstacles}

In the developed maize-growing countries like, for example, the United States, genetic improvement, seed production and distribution systems have been in place for around a century. But in the developing world they have a short track record. Nevertheless, some impressive gains have been achieved, particularly with new open-pollinated varieties. Important gains in yield have been attained, and Thailand has been successful in producing varieties resistant to downy mildew, a disease responsible for heavy crop losses.

Seed industries have reached varying stages of development. In each country the government intervenes to varying degrees in seed production, testing and quality control, and marketing. In Thailand and Brazil, the public sector accounts for only a small share of the production of maize seed, in Mexico the major share, and in Indonesia it still accounts for an overwhelming portion. The public sector is also involved, directly or through extension services, in the marketing of the seed of open-pollinated varieties. Hybrid seed, in contrast, is marketed essentially through private firms, both domestic and multinational corporations.

A constraint common to all countries is that the financial and human resources available for public R\&D are extremely limited. In some cases they are declining as a 
result of the general process of structural adjustment in agriculture and of inducements to privatise.

In all four countries there are major obstacles to the domestic development of new maize biotechnologies. At present, although each has national biotechnology programmes in human or animal health care and plant biotechnology, very little public research effort is devoted specifically to maize, despite its importance as a food and feed crop. Furthermore, the problem of limited financial resources is compounded by a scarcity of scientists in the scientific disciplines of biotechnology (biochemistry, microbiology, molecular biology). Equally important, but often overlooked, plant biotechnologies will for the most part continue to be embodied in seeds and thus will complement but not supersede conventional methods of plant breeding and genetic manipulation. And technological capability in these methods still requires strengthening.

\section{Technology from Abroad?}

Can the international transfer of technology accelerate the introduction of new biotechnologies? In the past, the International Agricultural Research Centres ${ }^{3}$ and for maize the International Centre for Wheat and Maize Improvement (CIMMYT) have been a vital non-market source of technical assistance and of improved germplasm (seed used as breeding material) for national plant-breeding programmes in developing countries. Bilateral aid has also played an important role in supporting national agricultural research programmes and the building of local technological capability.

But a rapid increase in commercial sources of new technology in the form of germplasm and seeds ('embodied technology') and expertise ('disembodied technology') is more problematic. Although commercial seed imports into the developing world are increasing, the inherent botanical properties of plants and the necessity of a period of adaptation to specific locations, climatic conditions and production systems tend to put a natural limit to the scope for international trade in seed and to make local production the

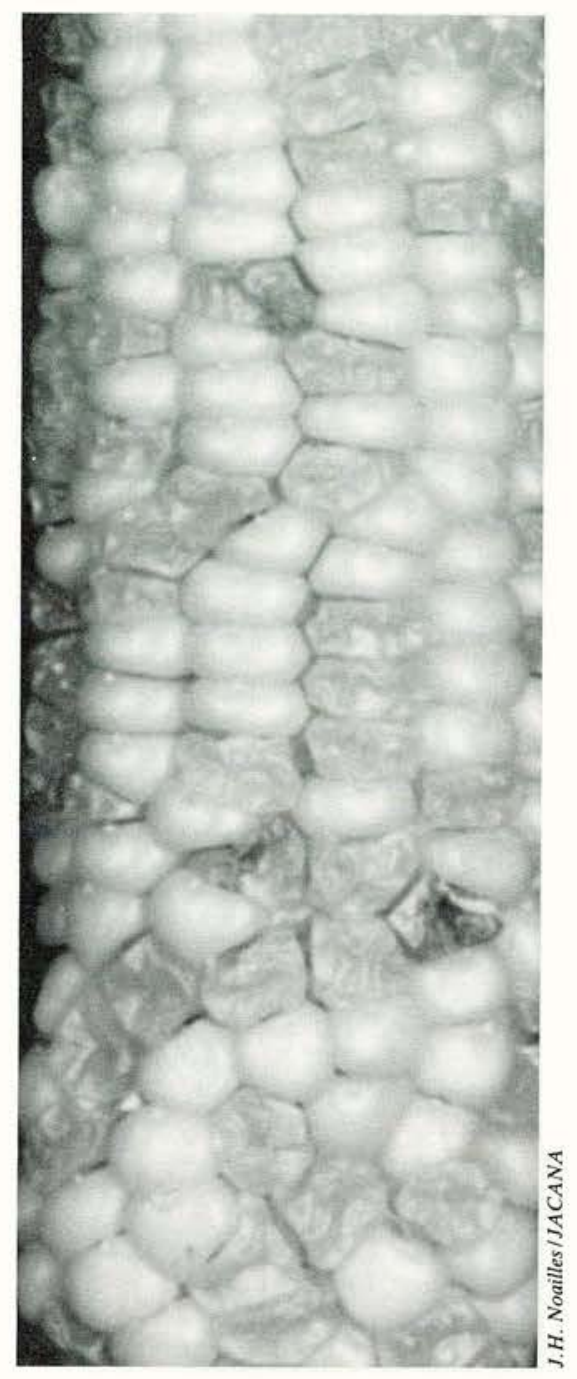

dominant source of supply for most countries. Other constraints and incentives arise from the increasing importance of private firms in the development of the new biotechnologies and the related issue of the protection of intellectual property rights (IPRs).

\section{Public v. Privałe?}

In all four of the countries studied, government intervention is in general prominent throughout each aspect and phase of the research, technology development and delivery system for maize. And there are strong arguments in support of public research and intervention in developing-country agriculture. Public research is important, for example, in the classification and inventory of indigenous genetic resources and in exploring longterm research objectives that the private sector might consider either unprofitable or unpromising. It is also important that public-sector institutions keep abreast, as far as possible, with the latest advances in biotechnology in fields of particular interest to them. But even with more efficient allocation, it is clear that the limited public resources available are inadequate for the magnitude and complexity of the task at hand.

Except in Brazil, where the national (private-sector) firm Agroceres has spearheaded the research effort, privatesector research in agriculture is still limited in both volume and scope. Nonetheless, private-sector involvement is expanding in seed production and marketing, despite such disincentives as narrow profit margins for seed sales, the limited size of the actual or potential seed market in some countries, cumbersome regulatory processes for research authorisation, importing germplasm, varietal certification, and so on. Multinational corporations supplying seeds and/or agricultural inputs (Pioneer, Cargill, and DeKalb, for example) are present in all four countries, even though their share of the total market in maize seed may be relatively small.

An expanded role for the private sector in basic, adaptive or applied research in developing country agriculture, as well as the prospects for importing new biotechnologies (or elements thereof) are increasingly linked to the issue of the protection of intellectual property rights. ${ }^{4}$ These can be protected, in plants, through patents or through a form of plant breeder's rights which ensure royalty payments to the 'innovator'.

This will inevitably imply more emphasis on hybrids, as private firms can then recuperate a share of research costs and make a profit, even in the absence of a formal system of protection of IPRs. But none of the four countries examined has yet introduced a system of IPR protection for seeds. Furthermore - unlike most OECD countries - none has yet adopted legislation on the broader issues of IPRs

3. A network of institutions, set up to support agricultural research in developing countries, funded by bilateral and multilateral agencies, co-ordinated by the Co-ordinating Group for International Agricultural Research (CGIAR), which has its offices at the World Bank, Washington DC.

4. See Bernard J. Phillips, 'The Patent Paradox in Competition Policy', The OECD Observer, No. 159 , August/September 1989. 


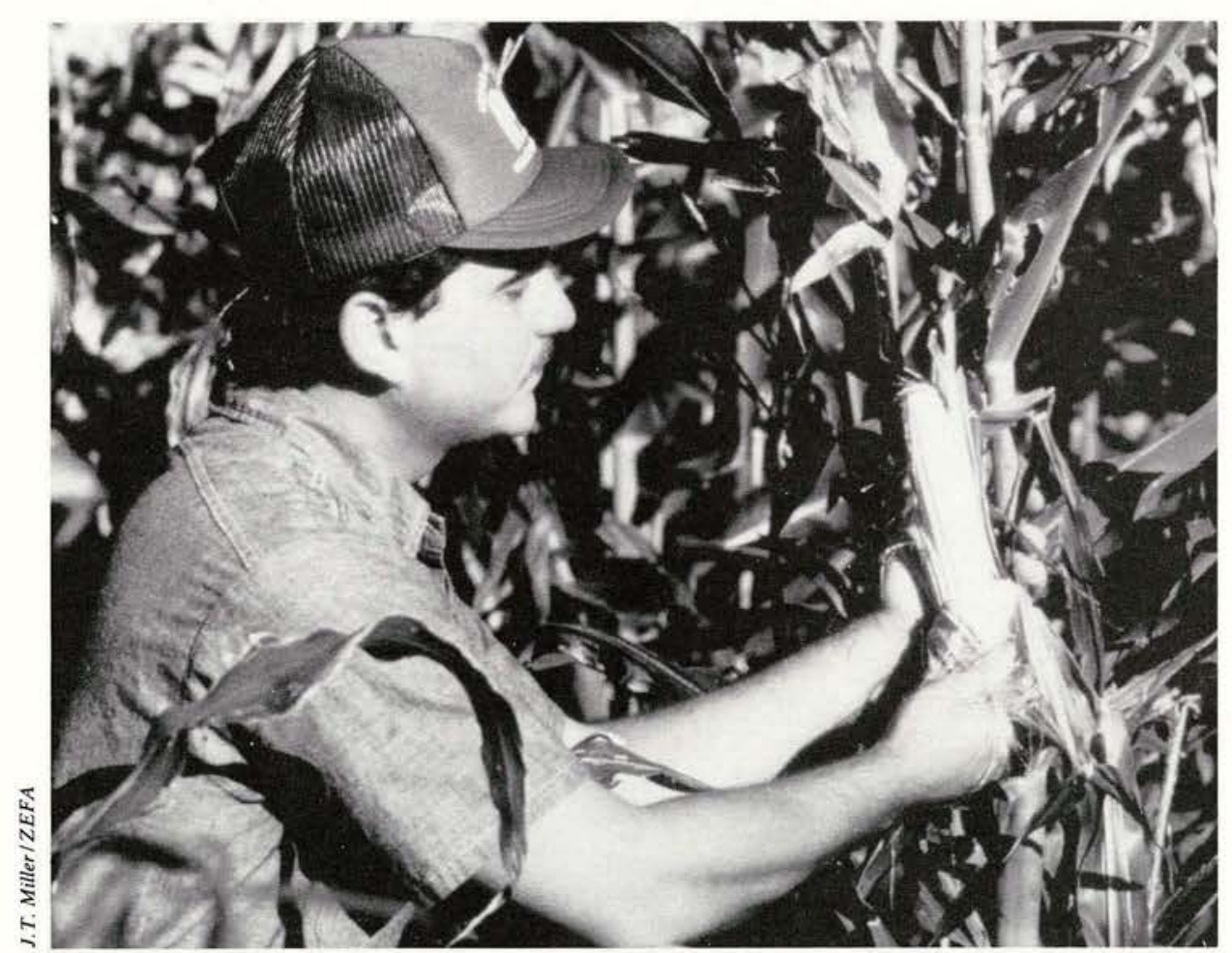

for plants, animals and micro-organisms, which is an increasingly contentious issue in debates on new biotechnology, although all except Thailand recently made changes in their patent laws. And without IPR protection, foreign firms may be reluctant to 'transfer' biotechnology to developing countries.

\section{What Hopes from Biotechnology?}

For developing countries, biotechnology offers the hope of enhancing both quantity and quality in agricultural production. It also offers the possibility of reducing the present lengthy period of several years required to develop a new variety, as well as new techniques to assist in analysing and monitoring indigenous crop genetic resources and, perhaps, identifying genes with special properties.

The lessons from maize illustrate that, in the short term at least, and with variations according to economic development, scientific and technological capability, and technological achievement in agricultural production, many developing countries will be unable to develop new plant biotechnologies domestically to any significant degree. Quite simply, they lack national financial, scientific and technological resources, public and private. This could have serious consequences for food self-sufficiency or competitiveness in international markets. new biotechnologies can be imported. Laboratory techniques can be learnt and replicated in different sites. But where biotechnology is imported embodied in seed, its performance may vary appreciably from one environment to another. So there are natural limits to technology transfer in the form of seeds, at least without a period of adaptation to local conditions. In addition, access to new biotechnologies will increasingly require the protection of IPRs.

In many developing countries privatesector activity in agricultural R\&D is weak,
What is less clear is the extent to which despite the general trends towards privatisation and a diminished role for the public sector, associated with the structural adjustment process. If the private sector is to play a larger role, it may be necessary to provide incentives to firms (for example, by adhering to a form of IPR protection), or at least remove some of the present disincentives, such as cumbersome regulatory processes for importing germplasm or for certification of a new variety.

It may also be necessary to explore innovative forms of public/private sector collaboration (for example, collaborative research with small, foreign biotechnology firms, NGOs, or members of the international scientific community) in order to increase the total volume of resources devoted to biotechnology R\&D. It is also clear that public/private complementarities could be better exploited than at present and duplication of effort avoided.

Finally, financial aid and technical assistance - through bilateral and multilateral institutions and, especially, through the International Agricultural Research Centres - have to date played a crucial part in the development of national agricultural research systems and in the development of seed industries in developing countries. If developing countriesparticularly low-income countries where total resources for R\&D are small - are to be able to keep their technology options open in the future and, as and when appropriate, take advantage of new plant biotechnologies, there will be a continuing, long-term call for such assistance.

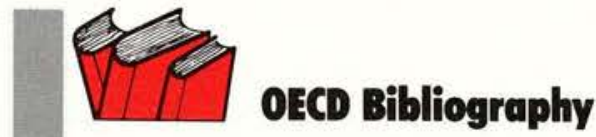

- Biotechnology and Developing Country Agriculture: The Case of Maize, 1991

- Jacques de Miramon,

'The International Interest in Intellectual Property', The OECD Observer, No. 163 , April/May 1990

- Competition Policy and Intellectual Property Rights, 1989

- Bernard J. Phillips, 'The Patent

Paradox in Competition Policy',

The OECD Observer, No. 159, August/ September 1989

- Salomon Wald, 'The Biotechnological Revolution', The OECD Observer, No. 156, February/March 1989. 


\title{
Information Technology and the Future of the City
}

\begin{abstract}
Rémy Prud'homme
New technologies are leaving their mark on every aspect of urban life - traffic, health care, the location and nature of employment... How will these changes affect urban development? How can they improve the way modern cities function? The OECD helped organise a conference to address these questions at the Cité des Sciences et de I'Industrie at La Villette, Paris. ${ }^{1}$
\end{abstract}

$\mathbf{T}$ he city, the cradle of civilisation, has always been the place where information is produced, stored, used, traded and sold. A city is a commercial, financial and cultural centre where news on markets, financial data or ideas about the world in general are produced and transmitted.

Venice, perhaps the archetype of the modern city, owed its prosperity to both the quantity and the quality of the information circulating within its walls - the availability of spices in Alexandria, the demand for wine in England, the political situation in Asia Minor. The heart of the city was not the port, where goods changed hands - it was the Rialto, where news was traded.

A city is first and foremost an exchange. And exchanges have always been located in urban centres, since by definition their purpose is to gather together in the same place men and women with something to trade.

But is the supremacy of the city, or its monopoly, now under threat? If so, it is certainly not because information has be-

Rémy Prud'homme was formerly the Director of the OECD Environment Directorate and is now Professor of Economics at the University of Paris XII. He was chairman of one of the workshops at the La Villette conference on 'New Technologies and Economic Development'

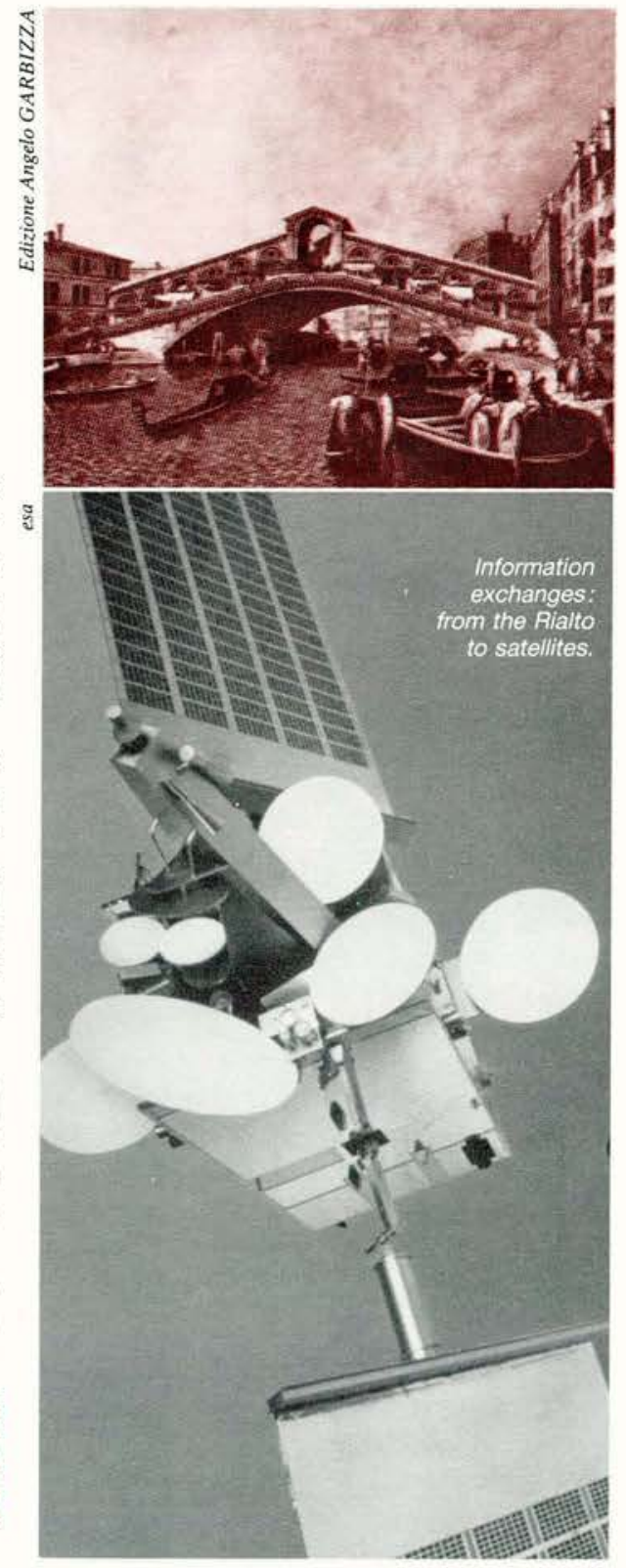

cume less important. Demand for information - or the amount of information produced - has never been as big as it is today. The share of services - that is, of information - in both final household consumption and intermediate consumption by firms is steadily increasing, at the expense of goods. It has been calculated that over $60 \%$ of the labour force of the developed countries is engaged in jobs that consist primarily of handling information.

Yet the supremacy of cities may be jeopardised by new developments in the field of information technology. Clearly, information technology, like any other technology, has always had to adapt itself to innovation. The invention of the printing press and the telephone, for example, led to major changes in the way in which information is conveyed. The difference now is that the pace of change seems to have increased dramatically over the last ten years or so.

Computers a hundred times more powerful than those available ten years ago can now be bought for a hundredth of the cost -

1. 'Cities and New Technologies', international conference organised by URBA 2000, the Délégation Interministérielle à la Ville et au Développement Social Urbain, the Association des Maires de France and the OECD at the Cité des Sciences et de I'Industrie at La Villette. 


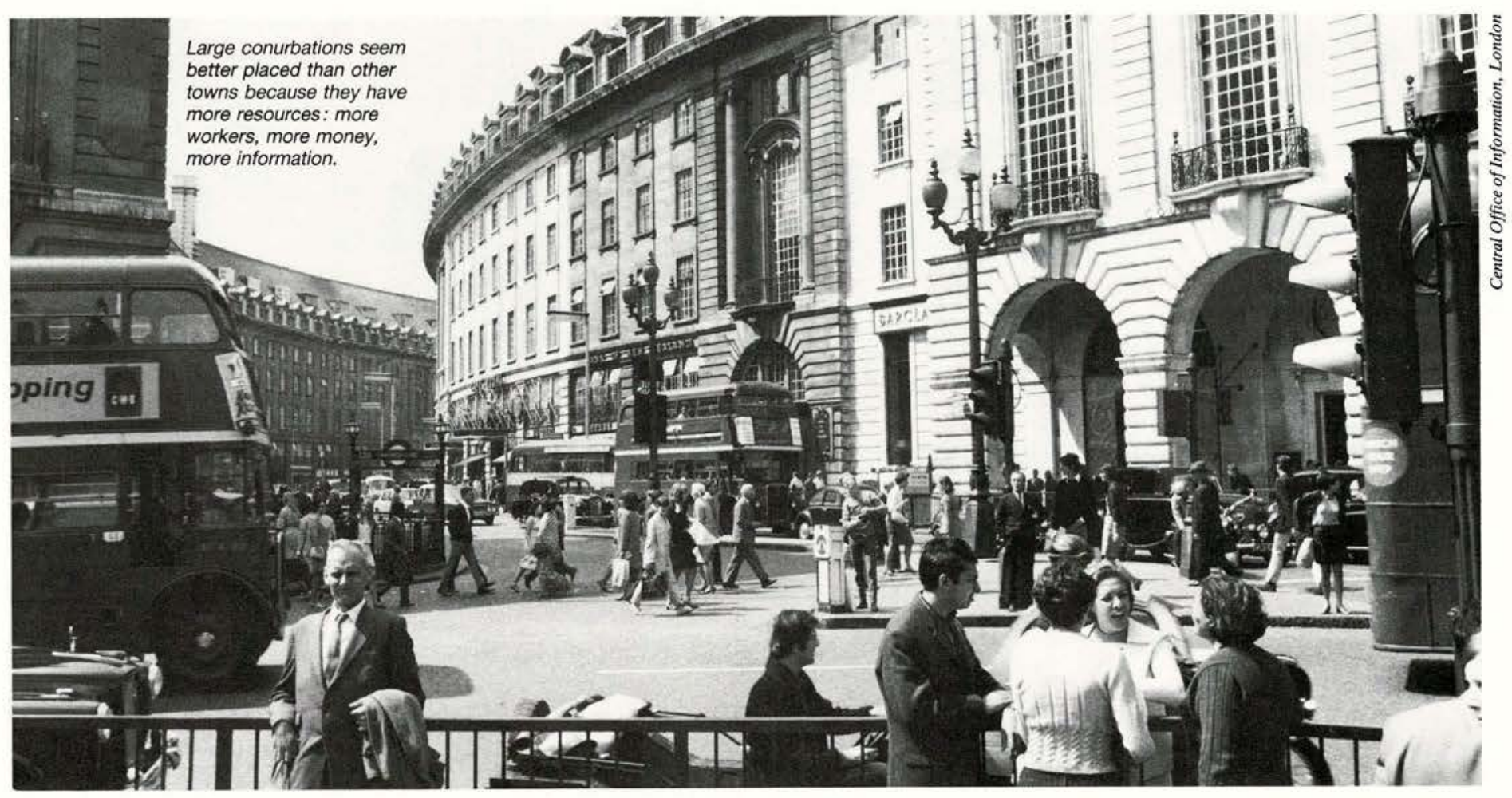

computers with more capacity than those used by the Pentagon during the Vietnam war can now be found on supermarket shelves. Meanwhile, the transmission capacity of telephone networks has similarly increased by several orders of magnitude, as a result of the development, for example, of satellite systems and fibre optic cables.

It is basically the marriage of telephone technology and computers ('enhanced telephone systems' and 'supercomputers') that has given rise to the 'new information technologies'. Virtually unlimited amounts of information can now be transmitted to any destination at any time of the day, and at little cost. These new technologies have broken down the spatial and temporal constraints on information. The question that must now be asked is what that means for the city.

\section{Economic Development}

An attempt at an answer requires an economic approach, to ask what impact these new information technologies will have on the economy. The answer to that question is that they contribute to global economic development in two specific ways. First, they allow men and machines to produce more and better goods and, by eliminating waste, mistakes and repetitive tasks, they boost productivity. This is already the case in the automobile industry; tomorrow it will be a reality in health care and education.

Second, and more important, the new information technologies make it possible, or will make it possible, to reap the full bene- fit of two developments already in progress: the globalisation and liberalisation of world markets. National economies are fast becoming part of a global economy: trade is intensifying and most goods can now be bought and sold virtually anywhere in the world - with one or two exceptions that the OECD is attempting either to eliminate or to limit. At the same time, and partly in conjunction with this trend, economies are becoming increasingly open, as the scope of regulations, licences, constraints and restrictions that governments impose is gradually shrinking.

These two major trends have opened up dizzying vistas for economic agents in the options now open to them. But making those choices entails 'transaction costs'. This is where the new information technologies come into their own. They can help to reduce such costs, thus allowing economic agents to grasp the opportunities now on offer. Efficiency is based on freedom of choice. And exercising freedom of choice requires the use of information technology.

Yet the increased economic activity that will be generated by the use of new information technologies will not be evenly distributed. The increment will not be shared out pro rata, following the existing status of different sectors or different areas. At least three mechanisms are involved, all of which have implications for the location of activity - that is, for the future of cities. The new information technologies will give rise to new products, new processes and modes of production.

First, new products. The goods and services that will be produced and consumed will bear little resemblance to the present mix. Lower costs, improved quality and the appearance of new products (which cannot even be imagined at present) will revolutionise the structure of goods - and, above all, services - produced and, by the same token, the spatial distribution of production facilities.

Second, new processes of production. The new information technologies will have a similar impact on production processes. Their effects on the production of goods are beginning to be seen: factory automation, increased specialisation of firms (resulting in the rapid development of freight transport), the replacement of raw materials and energy by information, and so on. The impact on services is less noticeable at present, and in particular on the two most important: health care and education. But there can be no doubt of the impact that information technologies will have on the geographical location of both people and activities.

Finally, new modes of production. New concepts, such as firm networks, or the standardisation of trade in information (the result of the development of electronic data interchange) are starting to emerge and to be used on a wider scale - again, with spatial implications.

\section{Opportunity or Threat for Cifies?}

Are these changes an opportunity for cities (and if so, for which ones?), or are they, on the contrary, a threat to their continued existence? Will these new techno-

2. Mark Hepworth, 'Information Services and Local Economic Development', paper presented at the La Villette conference. 
Fibre optic cables have had a powerful effect in increasing the capacity of information technologies.

logies attract people to cities, or will they drive them away? Do they both intrinsically and automatically strengthen the pull of cities, and in particular large cities, or do they encourage activities to spread into smaller urban centres, run-down suburbs or rural areas? At present, no one can confidently predict the outcome.

It can be argued that the increased importance of information and easier flows of information (the two major advances offered by the new technologies) will allow both firms and people to operate from any location, and will thus lead to the decentralisation of activities and a concomitant decline in the importance of cities or, at any rate, the major cities.

Teleworking - working from a computer terminal in the home linked to a large number of existing data banks, in a calm and pleasant location, far from the noiseridden, polluted environment of the city will become easier and far more popular, emptying the cities of a least some of those involved in handling information. Teleconferences and fax machines will do away with meetings and the concentration (on either a permanent or temporary basis) of economic agents in the same, and obviously urban, location. In short, there will no longer be any call for exchanges located at the centre of the city, since their work can now be carried out by a host computer located anywhere.

Conversely, it can be argued that the growing volume of activities in creation, design, training, organisation, management, co-ordination, information, and also recreational, cultural, social and religious activities, will generate an increasing demand for people to speak, meet and trade with one another, a demand which can be satisfied only by even larger cities. A business merger cannot be negotiated over a computer link any more than psychoanalysts can conduct their consultations over the telephone. In this light, cities would seem to be more necessary than ever, both as the location for productive activities and as that for household consumption.

Developments over the last few years would seem to confirm the second approach - as does the somewhat older example of the telephone. Far from reducing interpersonal contacts, the telephone if anything would seem to have increased

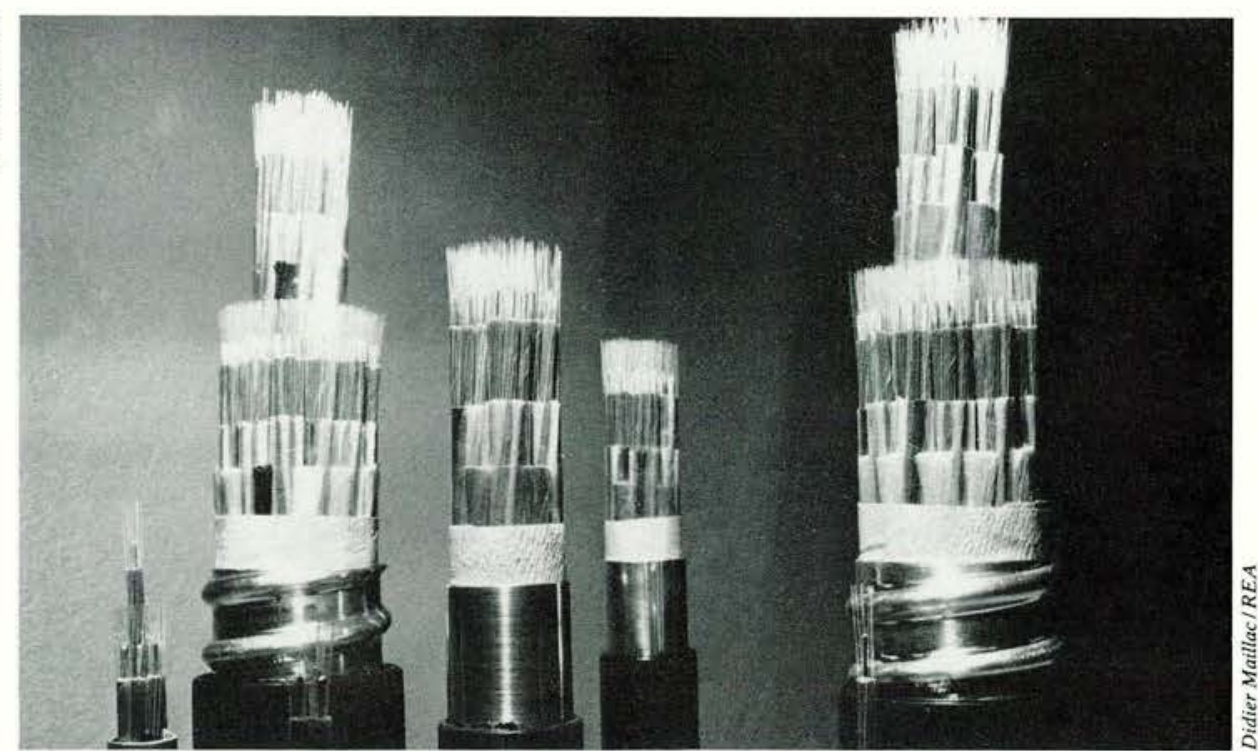

them. And teleworking, which the futurologists of the 1970 s predicted would become a major growth area, has so far remained marginal.

At the same time, a counter-trend has been witnessed in which the relative attractiveness of major cities, and city centres, has grown, as shown by the increase in property prices. They reflect the interest shown by firms and households in locating in a given spot, and hence the attractiveness of that location. They thus have clearly always been higher in large cities than in small towns, and higher in the centre of these cities than in the suburbs. But the difference between property prices in large cities and those in small or medium-sized cities, that is, the attractiveness of large cities over small cities, has not always been constant. This difference, which shrank in the 1970 s and early ' 80 s, has apparently grown steadily wider since 1985 , suggesting that major cities, and particularly large conurbations like London, New York, Tokyo or Paris, are becoming increasingly sought after as locations.

Will the new information technologies encourage more activities to spill into the suburbs?

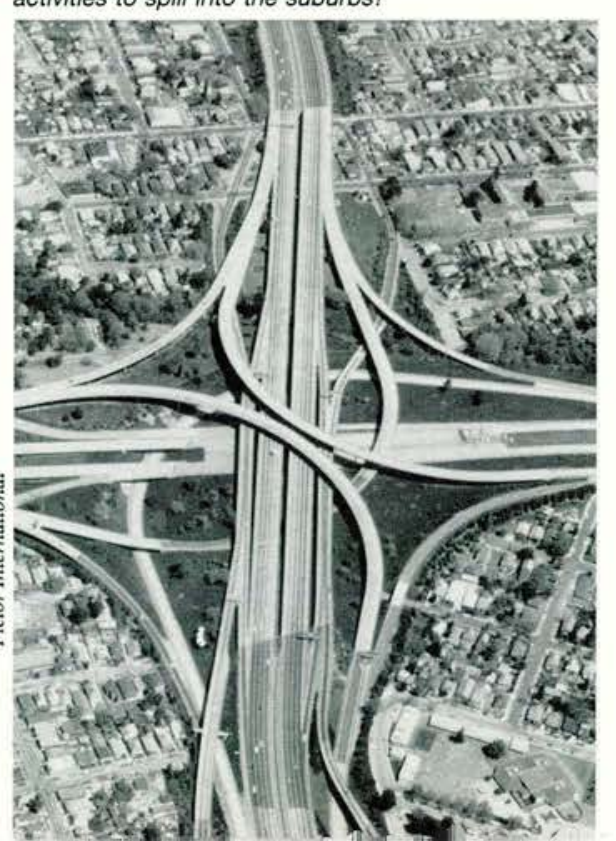

Two conclusions emerge from predictions of future trends, although they have to be treated with caution. The first is that there is undoubtedly a wide range of possibilities. The new information technologies do not militate openly for or against cities. They simply erode geographical determinism. They are just as likely to encourage as discourage the concentration or dispersion of people and activities. They merely offer people a choice, regardless of whether they live in a major conurbation or a rural area.

The second is that these technologies can be dangerous. A first reaction might be to think that some cities, notably large metropolitan cities, would be better placed than others to seize this opportunity, given their larger initial resources in terms of skilled workers, financial assets and, last but not least, information. But even though the precise impact of the new technologies cannot be determined, they would seem to attract more people towards cities than they encourage to leave. It is therefore possible, and indeed probable, that they will help to draw people into large cities. Fears of rapidly decaying cities would therefore seem to be unfounded. Yet any relief this prompts may prove to be shortlived, since renewed urban growth is accompanied by at least three serious threats to society.

\section{The Dangers of Renewed Urban Growth}

The first danger is political. Large metropolitan cities are already the wealthiest areas in any given country. Renewed growth would merely exacerbate existing differences between richer and poorer areas of every OECD country, which would be hard to justify in political terms. Over the last fifty years, these differences, which are often referred to as 'regional disparities', have slowly but surely nar- 
rowed. One of the main mechanisms behind this erosion has been the tendency of firms to locate in areas where salaries are lowest, in areas which, by definition, are the poorest. Firms will always want to locate in areas where salaries are lowest, but nowadays they are even keener to locate where information is plentiful or, to be precise, where there are people capable of exploiting information, that is, in large cities and the wealthiest regions. Because of the growing importance of information the mechanism which automatically reduced regional disparities has been displaced by another mechanism which automatically exacerbates them.

The second danger is physical. The major cities are already beginning to choke to death under the combined impact of congestion and pollution. Unchecked growth would soon make them unmanageable, to the benefit of nobody. Congestion and pollution are classic externalities. By locating in a city because that is where it finds what it requires, a firm (or a household) imposes costs on others which it does not have to pay itself and which are larger than the benefits it receives. The costs are borne by society.

The final danger is a social one. The exploitation of information and the new information technologies calls for training, effort and talent. It requires a certain expertise that not everybody is able to offer. The development of information technology, particularly in urban areas, when cities in the developed world must contend with rising immigration from poorer countries, may well widen the gaps that already exist between different social groups. 'Two-speed' cities may emerge. The reason that the attack by two unemployed youths on a yuppy in Central Park in New York caused such an outcry is that it was more than a news item: it had symbolic value.

\section{What Recommendations for Action?}

This brief overview of the opportunities which the new information technologies offer cities, as well as the dangers they represent, naturally prompts a number of recommendations for economic policy. The analysis suggests that economic policy- makers can influence developments, maybe more in this area than in others, and that is exactly what they are doing. These recommendations are addressed to central governments, regional authorities, and also, perhaps, to firms.

Clearly, central governments must help the development of the new information technologies; to a certain extent this development will depend on their decisions and their investment. These technologies are generally profitable, so in most cases it is both unnecessary and undesirable for them to be funded by the public purse. But this is not always true and, indeed, in some respects these technologies are potentially monopolistic and should therefore be regulated. The problem is how to regulate the sector without stifling it.

Above all, central governments must stiffen their regional development policies. If current developments exacerbate regional disparities as feared, they will have to be countered by vigorous policies designed to support regions which are either lagging behind or are under threat. These policies will be harder and more expensive to implement since, instead of supporting a mechanism, they will now have to reverse a trend - and it is always harder to sail against the wind than with it. Yet such policies are essential. It central government cannot maintain a certain balance between the regions and between cities, who can?

Local authorities - regional bodies, cities, intermediary organisations - will have a major role to play in introducing and supervising the new information technologies. The answer to whether the state, local authorities or firms should take the lead would seem to be the local authorities. Almost all the initiatives described and discussed at the OECD conference were sponsored by local authorities. So what are they doing? And what can they do?

First, they can encourage firms producing or using new information technologies to locate in their area. But there is a paradox here. These technologies, which allow their users freedom of location, are starting to be adopted by firms which are themselves firmly rooted in a given location and which have a higher growth rate than other firms, either because they produce the technologies or because they use them. This fact has not escaped the notice of town planners who have accordingly set up teleports or specialised zones.

Local authorities can then use the new information technologies themselves to manage municipal public services. They are not doing this simply to set an example:

\section{In spite of expectations to the contrary, teleconferences seem not to have done away with business meetings.}

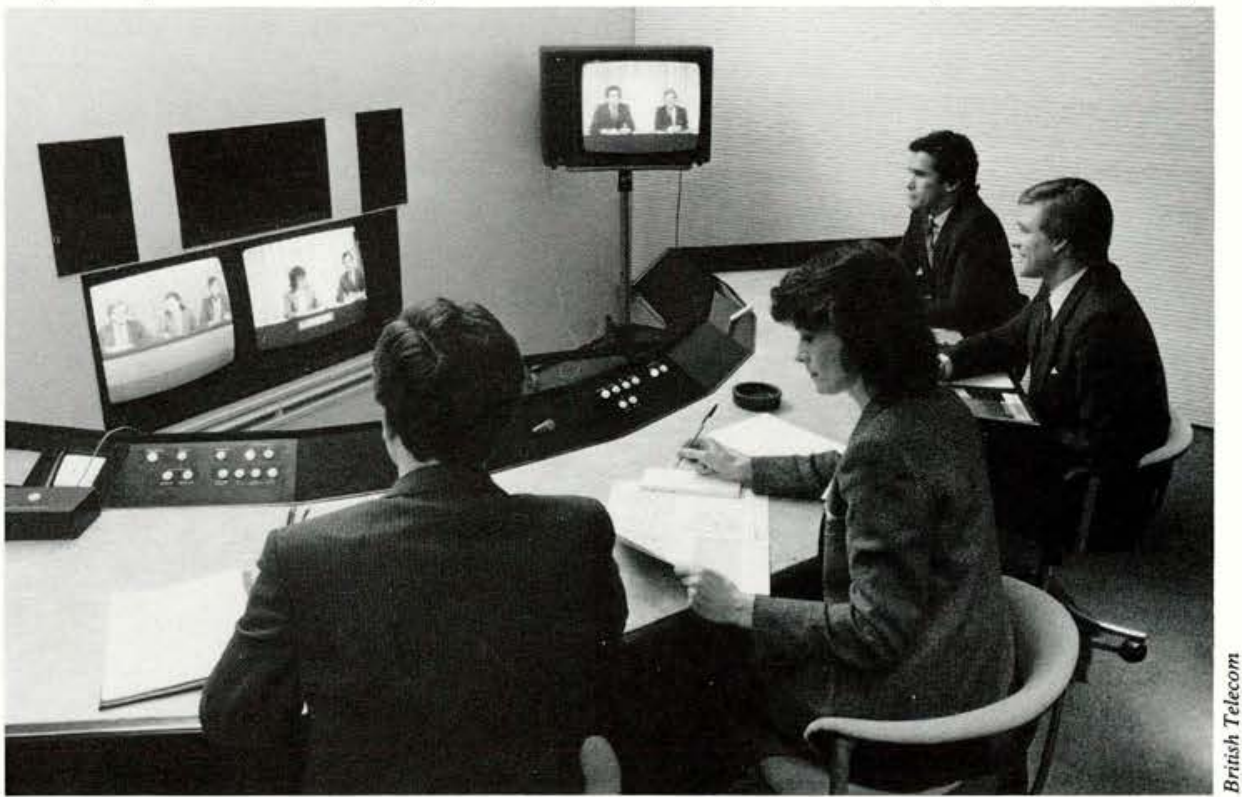




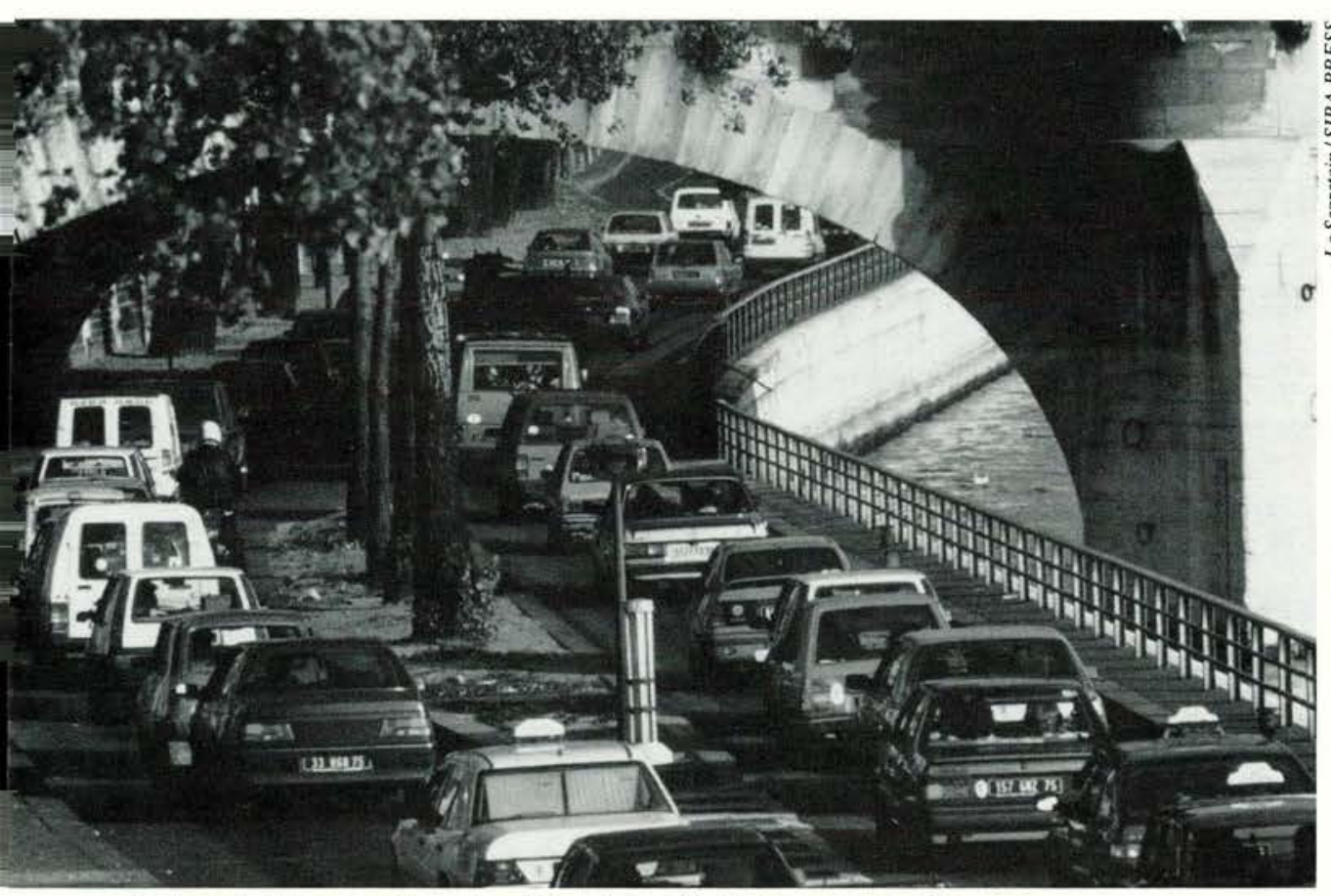

'On-board' electronic systems allow drivers to be billed for the congestion they cause.

although the introduction of new information technologies may well encourage unchecked, and ultimately unmanageable, urban growth, it simultaneously offers the means to manage ever-larger cities. New information technologies are both the sickness and the cure.

There are many examples of this phenomenon. $^{3}$ Road pricing, which makes motorists pay for the congestion they cause - the economist's dream - has now been made possible through the development of on-board electronic systems. Soon all drivers will be receiving traffic bills alongside their telephone bills, which will make sure that they do everything in their power to reduce the congestion for which they are responsible, and which will thereby help to improve traffic flows (providing that the price is high enough) more than any regulations that can be devised could ever do. Another example is in preventing damage to property or personal injury. Videomonitoring and the transmission of electrocardiogram data, coupled with the provision of

3. Gabriel Dupuy, 'New Information Technologies and Utility Management', paper presented at the La Villette conference. emergency response teams, offer possibilities that are only just beginning to be exploited.

Cities must subsequently concentrate their efforts on training. Poor or non-existent training facilities are a major obstacle to the development of new information technologies, and are probably the principal cause of the emergence of 'two-speed' cities. To attract firms and ensure social stability, it is better to have trained workers without a teleport than a teleport without trained workers. Local authorities, as many delegates to the OECD conference stressed, must also beware of trends in fashion, which might prompt them to devote all their resources to the development of new technologies while abandoning or neglecting more conventional programmes or infrastructure. Social aid and public transport - whose efficiency can be improved by using these new technologies - must continue to receive their full attention and a large portion of their budget allocations.

Firms, particularly large firms, will undoubtedly be called upon to play the part incumbent on them in developing the city. Obviously, their main task is to lower costs, within the confines of the law, and to create jobs, and in this respect the imperative of turning a profit will force them to meet the challenge. But is this enough?

Can one now accept the classical, strict division of labour between an economic power which produces goods and services and a political power which regulates that production? The interests of the public and private sectors coincide so closely in new information technologies that the question simply cannot be avoided. The decisions taken by firms have such an impact on the life of the city, and the decisions taken by politicians have such an impact on the profits made by firms, that to hold 'every man to his trade' would probably be inappropriate both for firms and for cities. Many industrialists would be the first to admit the truth of this statement, and to want to play a bigger role in the life of their city or their region. The forms and rules for such participation concern everyone.

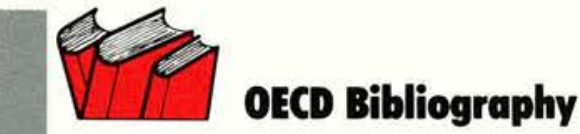

- The State of the Environment, 1991

- Fighting Noise in the 1990s, 1991

- Ariel Alexandre and Jean-Philippe

Barde, 'Deaf Ears on Noise Pollution',

The OECD Observer, No. 167,

December 1990/January 1991

- Sergio Arzeni, 'Tourism in

Mediterranean Cities', The OECD

Observer, No. 164, June/July 1990

- Environmental Policies for Cities in

the 1990s, 1990

- New Technologies in the 1990s: A

Socio-Economic Strategy, 1989

- J. B. Opschoor and H. B. Vos,

Economic Instruments for

Environmental Protection, 1989

- Jean-Philippe Barde, 'The Economic

Approach to the Environment', The OECD Observer, No. 158, June/July 1989

- Urban Housing Finance, 1988

- Ariel Alexandre and Lindsay

MacFarlane, 'The City Reborn', The

OECD Observer, No. 153, August/

September 1988

- Managing and Financing Urban

Services, 1987

- Urban Policies in Japan, 1986. 


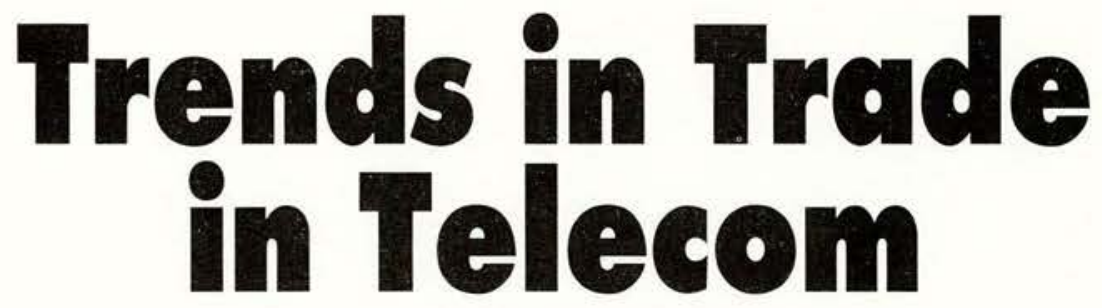

Amy Plantin and Dimitri Ypsilanti

$\mathbf{T}$ he basic concept underlying the market structure for telecommunication services was, until recently, that the plain old telephone service could be considered a natural monopoly. This assumption held that the provision of telephony would be most efficient if there was a monopoly with exclusive rights to provide all the services carried on the network. And the effects of this service monopoly trickled down into the process by which equipment was procured, producing in most instances a system of duopolistic supply. The rationale used to justify such a narrow procurement practice commonly included:

- establishing specifications and standards for equipment to guarantee that the network functions properly

- reducing life-time costs of equipment that requires a long-term software and hardware support, restricting the ability to change suppliers

- ensuring that the supply flow was not interrupted

- concerns of national interest and industrial policy.

Telecommunications administrations in a number of major equipment-producing countries have undertaken an industrial policy role in developing, protecting and administering not only the service industry but the equipment industry as well. Public telecommunication operators (PTOs) tried to obtain a minimum of price and product competition in equipment by dividing procurement between two or more firms, ignoring the fact that procurement on such a basis seldom brings about the competition that would arise from a truly open market.

Many of the OECD countries that do not produce telecommunications equipment, or all ranges of equipment, often maintain close ties with one or several producing companies, frequently on the basis of some offset arrangements. To a large extent, the supply of public telecommunications equipment has been on the basis of special relationships between PTOs and domestic vendors. In recent years the

\section{New technological developments can create new markets and render old markets uneconomic. As telecommunications services grow and develop, the demand for equipment to support them will have an important impact on the growth of domestic equipment markets, and on potential export markets. Liberalisation of telecommunication services also stimulates trade in equipment by allowing more competition within national markets. ${ }^{1}$}

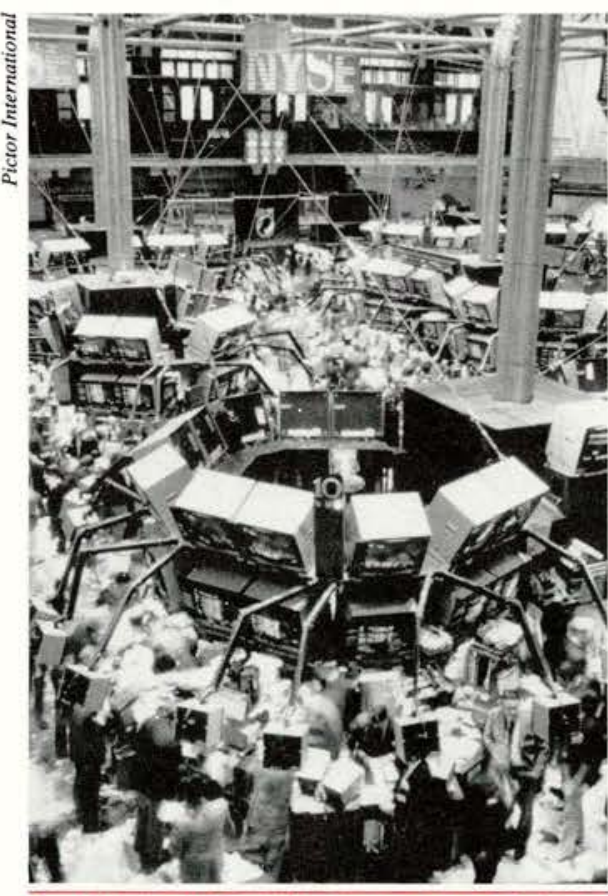

Amy Plantin and Dimitri Ypsilanti work in the Information, Computer and Communications Policy Division of the OECD Directorate for Science, Technology and Industry. relative importance of PTO procurement in total equipment purchases has shrunk. Part of this decline has occurred from the introduction of competition in public telecommunication services, as in the United States, United Kingdom and Japan. It can also be ascribed in part to the opening of the market for telecommunication terminal equipment to competitive supply and to the liberalisation of the rules specifying what can be attached to the network, especially equipment installed on customers' premises. The emergence of new equipment, or equipment for new services in which, in some cases, PTOs have not extended their monopolies, has also helped open markets.

Inadequate statistical classifications and data make it difficult to estimate the size of the world market for such equipment. Present estimates range from $\$ 60$ billion to $\$ 110$ billion. The OECD countries account for roughly $90 \%$ of all telecommunications equipment produced in the world. The production market can be broken into three broad market segments: central office switching, transmission equipment and customer premise equipment (CPE). Unfortunately these categories are not well defined in international trade statistics. For trade analysis the United Nations Standard Industrial Classification (Revision 2) has been used (box).

\section{Changes in Specialisation}

OECD exports of telecommunications equipment in 1988 totalled almost $\$ 16.5$ billion, an annual increase of $12.3 \%$ between 1978 and 1988 (Table 1). The market share of each of the equipment categories over the past ten years is shown in the Figure; it can be seen that line equipment is becoming more and more important in overall trade performance.

One indicator of trade performance is in

1. Telecommunications Equipment: Changing Markets and Trade Structures, OECD Publications, Paris, forthcoming 1991. 


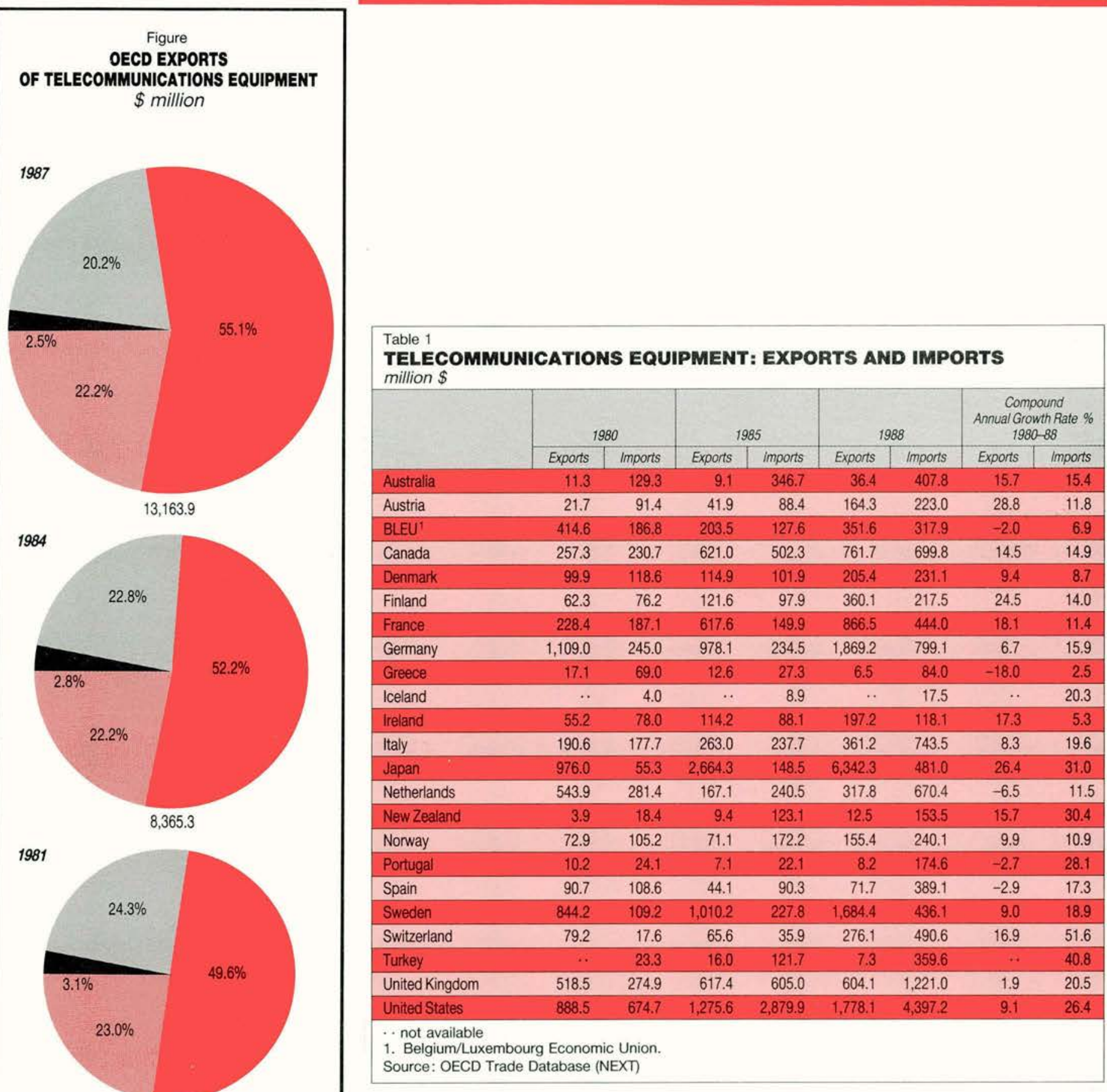

the measurement of changes in the structure of specialisation within manufacturing trade. These movements illustrate to what extent a country has specialised in trade of a particular commodity, compared to the OECD average. Of the ten major telecommunications-equipment trading countries, Finland and Japan have shown the largest increase in their relative specialisation of equipment exports between 1978

\section{WHAT IS BEING TRADED?}

There is no internationally agreed definition as to what constitutes 'telecommunications equipment products' for trade analysis. The OECD uses four of the United Nations' Standard Industrial Classifications (STIC):

- Electric Line Telephone and Telegraph Equipment (STIC 764.1) includes exchanges, switchboards, telephone apparatus, facsimile apparatus, teleprinter and teletype units, and so on

- Telephonic/Telegraphic Transmitters (STIC 764.3) includes multiplexer transmitters, relay apparatus, microwave transmitters, satellite microwave transmitters, and so on, as well as items which belong in the communications industry largely defined, such as television and radio equipment

- Telephonic/Telegraphic Receivers (STIC 764.81) includes multiplex, satellite microwave and terrestrial microwave receivers - Line Equipment Parts (STIC 764.91) for products in STIC 764.1. The third revision of these classifications will provide a more detailed breakdown of products, beginning with 1988 data. 


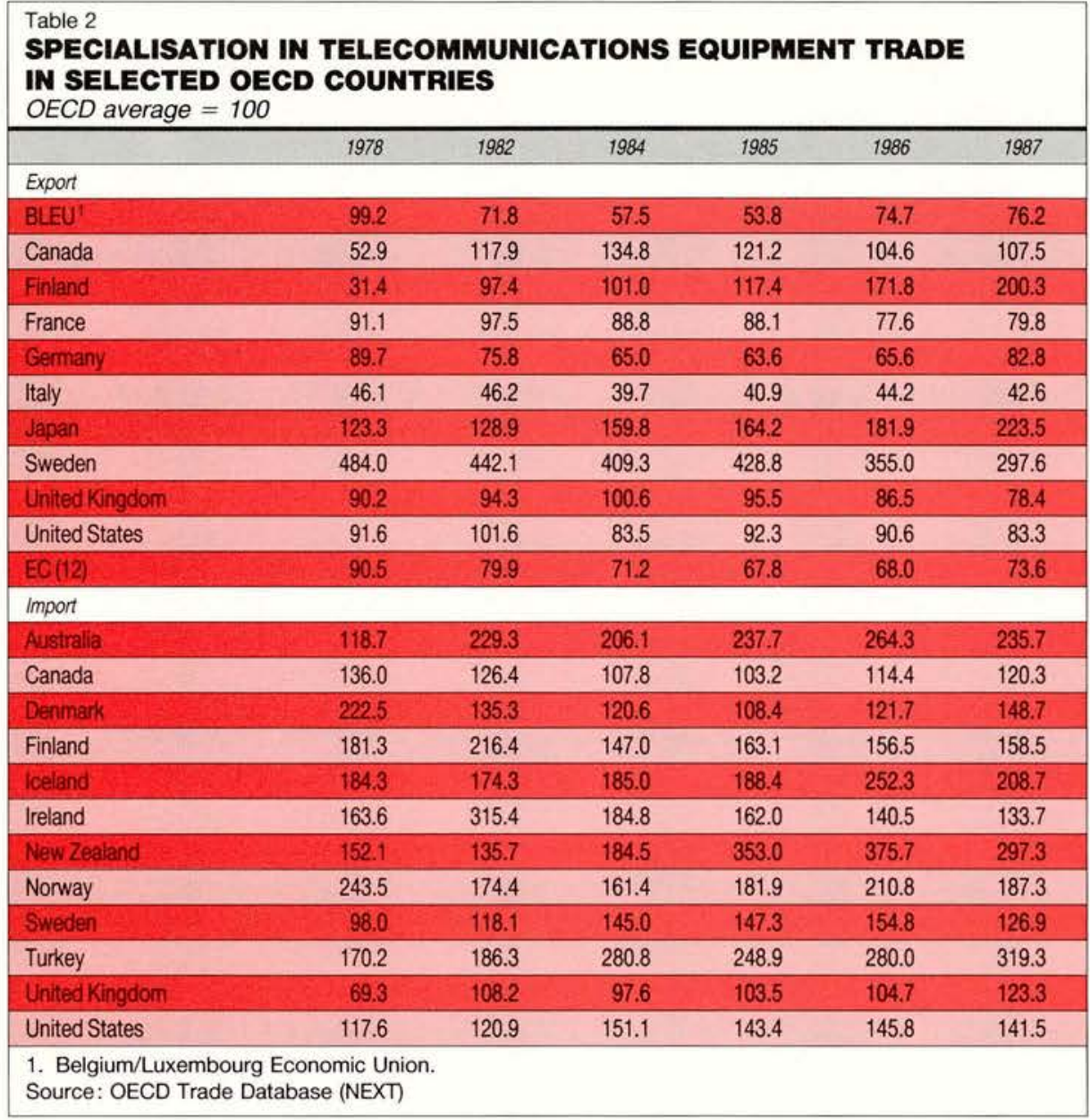

and 1987. Sweden continues to have a high degree of specialisation in the export of equipment among OECD countries despite a dramatic decline in this period (Table 2).

In imports a number of countries have depended heavily on external sources to support their network structures; Turkey, New Zealand, Australia, Iceland, Norway and Finland show a particularly large dependence on imports. Imports are also volatile, often reflecting new initiatives to upgrade or extend the basic telecommunication infrastructure; Australia, New Zealand and Turkey, for example, had high imports in the 1980s.

The markets for exports of equipment from OECD countries have been changing since 1980 . Then, some $20 \%$ of all OECD exports were sent to OPEC countries, in contrast with a mere $6.3 \%$ in 1987 . Markets in the newly industralising economies (NIEs) of Asia have increased rapidly, although the OECD area itself has become the most buoyant market.

In 1988, eight of the 24 OECD countries had a net surplus in equipment trade, compared to eleven in 1980 . For a number of countries, such as the United States, increased competition in customer premise equipment is reflected in a sharply increased balance-of-trade deficit. Most of crease of imports from Japan and the NIEs in the CPE market.

A number of factors have influenced trade patterns over the past ten years. Regulatory procedures, for example, have varied between countries for attaching terminal equipment to the network. Delays in the approval of equipment, duplication of testing in certain instances, vague criteria for standards or specifications have also artificially closed markets to new entrants. In the past it has occasionally been stipulated that approval be sought on an installation-by-installation basis in order to provide time for indigenous manufacturers to acquire the technology to enter a market. In many instances the customer was required to obtain equipment directly from the PTO or its preferred supplier.

Standards have also had an effect on equipment trade. Through facilitating this deficit can be accounted for by an in- compatibility between equipment, markets can become more open. But standards can also act as a double-edged sword, since they can be used to ensure exclusivity of a network to a particular supplier. That is why governments and firms are giving increased attention to the economic role of standards and their impact on telecommunication markets.

In light of these changes it is necessary to recognise an important principle of international trade - reciprocity. Liberalisation has opened the telecommunications equipment markets of some countries to unrestricted international trade, but others have been slower in eliminating barriers, fearing the loss of the domestic market. As a result some manufacturers have easy access to a number of foreign markets while the market in their own country of origin is often difficult to enter. Such policies will be increasingly difficult to sustain.

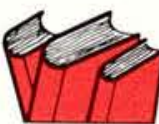

\section{OECD Bibliography}

- Telecommunications Equipment: Changing Markets and Trade Structures, forthcoming 1991

- Amy Plantin, 'The Brave New World of Telecommunications', The OECD Observer, No. 167, December 1990/ January 1991

- Dimitri Ypsilanti, 'The Cost of Calling Home', The OECD Observer, No. 167

December 1990/January 1991

- Theodore Darmaros, 'Investment

Trends in Telecommunications',

The OECD Observer, No. 167,

December 1990/January 1991

- Communications Outlook, 1990

- Performance Indicators for Public

Telecommunications Operators, 1990

- Trade in Information, Computer and Communications Services, 1990

- Dimitri Ypsilanti, 'A Framework

for Trade in Telecommunications

Services', The OECD Observer,

No. 163 , April/May 1990

- Telecommunications Network-

based Services, 1989

- The Telecommunications Industry:

The Challenge of Structural Change,

1988

- Satellites and Fibre Optics:

Competition and Complementarity, 1988. 


\title{
Overcoming Adult Illiferacy
}

\author{
Donald Hirsch \\ Illiteracy has long been regarded as a problem mainly for developing countries. \\ So why is the OECD bringing out a major study of literacy problems in advanced \\ economies? It is not because basic educational standards are falling, \\ but because basic educational requirements are rising. ${ }^{1}$
}

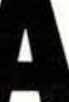
fter a century or so of universal education, many OECD countries are starting to worry about widespread adult illiteracy. Large employers frequently criticise the basic standards reached at school and complain that many workers lack simple literacy skills. But can it really be possible that in countries with anything from eight to eleven years'compulsory schooling there are millions of adults unable to read or write?

The answer turns on the definition of literacy and, crucially, on the uses to which it is put. The more alarmist employers are, quite simply, wrong if they mean to suggest that a significant proportion of adults are unable to decipher printed words. It has been estimated in America, for example, that about $98 \%$ of young adults can read and understand the written word to some degree. But that raises two crucial questions. What reading standard have those Americans reached? And is it adequate for their everyday requirements? As one commentary puts it, 'saying "Johnny can't read" is a bit like saying "Johnny can't cook". Johnny may be able to read the directions for constructing a radio kit, but not a Henry James novel, just as Johnny may be able to fry an egg but not cook Peking duck'. ${ }^{2}$

\section{Defining Illiteracy}

Firm assessments of the impact of illiteracy rely on a clear definition of what it is, and on some means of measuring its extent. Neither is easy. In the middle of the last century, being literate meant little more than being able to sign your name, and was relatively simple to measure. As mass education spread, literacy came instead

Donald Hirsch works on issues related to human re sources in the Centre for Educational Research and Innovation of the OECD. to be linked to the number of school years completed, or the grade attained. That criterion, while still permitting straightforward measurement, suffers from several flaws. It assumes that sitting in school is equivalent to learning. It fails to take any account of whether the skills learnt at school are usable in the real world. And it implies that an adult who has completed ten years of schooling will have the same reading skills at the age of 18 as at 65 , regardless of the extent to which those skills have been applied or updated. Indeed, the deterioration of fallow minds has helped make illiteracy a serious problem for the middle-aged - not only for marginalised young people. Thus illiteracy may be

1. Lauren Benton and Thierry Noyelle, The Literate Worker - Adult Literacy and Economic Performance in Industrialised Nations, OECD Publications, Paris, 1991.

2. Allen C. Purves et al., Becoming Readers in a Complex Society, University of Chicago Press, Chicago, 1984, p. 115. 


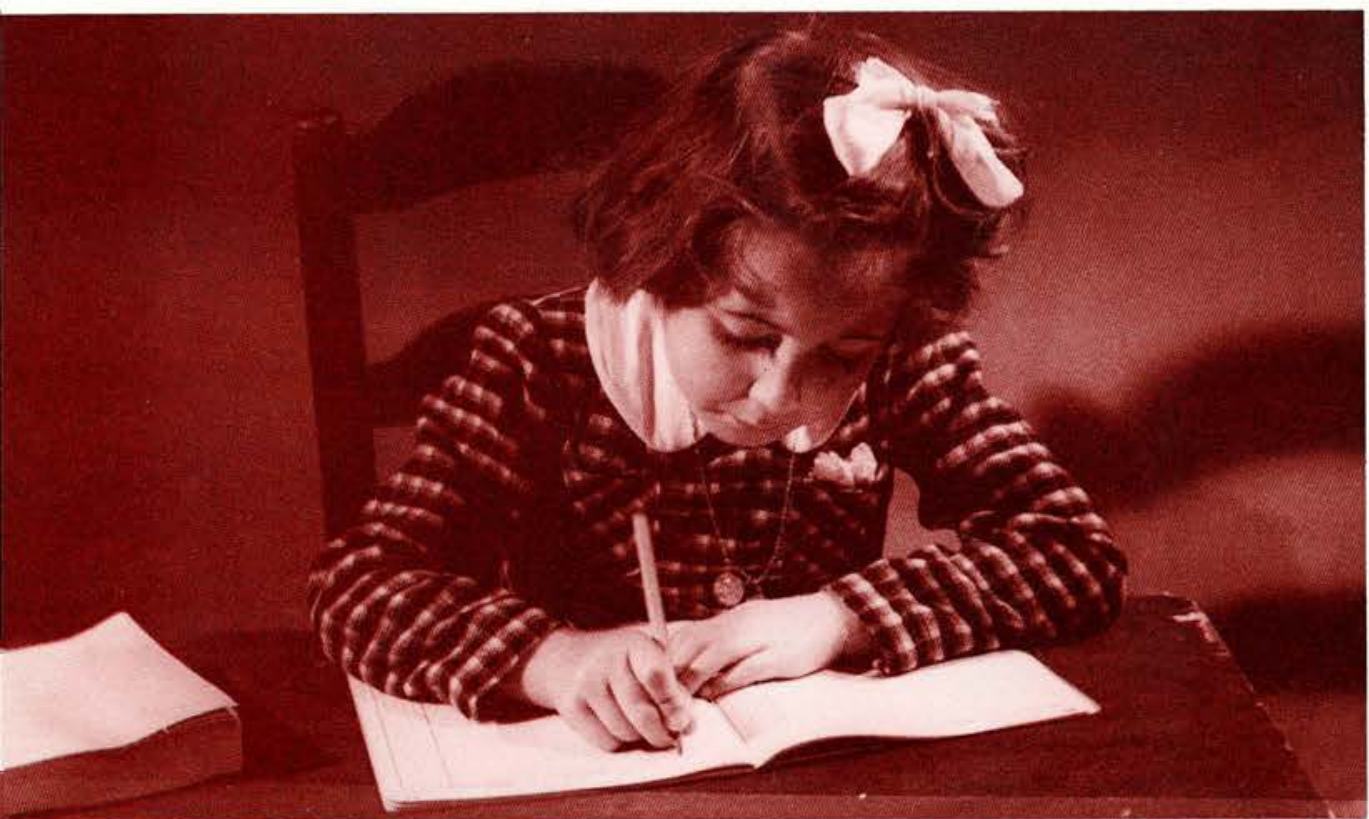

Governments still have a tendency to concentrate on initial school systems in response to complaints about badly educated workers.

viewed as a series of somewhat different problems for different groups - the two most visible being school dropouts in their teens and twenties who have never learned to read adequately, and underskilled workers or unemployed people in their forties and fifties whose skills have been overtaken by new job requirements.

It is commonly accepted today that it is functional literacy that really has to be measured. Roughly defined, functional literacy is the ability to use reading, writing and calculating skills to function effectively in one's own, everyday environment that is, at work, at home and in the community. The only sure way to find out if someone is functionally literate is to test that ability directly. Surveys are therefore expensive, but are being developed in the United States and Canada to degrees of increasing sophistication. France is also experimenting with such surveys, on a smaller scale.

These surveys provide a clue to why OECD countries are becoming increasingly alarmed about the question of literacy, and why the OECD itself is now publishing its first-ever report on the subject - under the auspices of its Centre for Educational Research and Innovation (CERI). The concern has been provoked, in short, not by a proven fall in standards of literacy but a clear rise in the standards of literacy now required. It is hard to monitor standards of literacy over time, not least because problems of illiteracy have not until recently been recognised or measured in OECD countries - and the OECD report is among the first of its kind. But recent changes both at work and in society at large have meant that literacy skills that were adequate twenty years ago are not necessarily
Level 1

Have difficulty dealing with any printed materials.

Level 2

Level 3

Level 4

Meet most everyday reading demands. so today. Those changes include the disappearance of large numbers of unskilled jobs, the changing use of skills at work and the emergence of a more sophisticated role for individuals as consumers of goods and services, both public and private.

But what is the evidence of the connections between literacy and economic performance? How clear a picture is there now of the extent of illiteracy? And what are the initiatives taken in different countries to tackle the problem? On each of these three aspects - economic impact, measurement and cures - there have been interesting recent developments, but much more knowledge is required before firm conclusions can be drawn. That deficiency can be ascribed to the neglect of the problem until recently.

A first step towards encouraging further international work would be to produce more accurate quantitative assessment of the costs of illiteracy. There is plenty of evidence that increased skills can contribute both to the earnings of individuals and to the output of firms, but that produces only indirect evidence of the cost of skill deficiencies. Employers' perceptions of that cost are closer to the mark; in one recent Canadian survey, one-third of businesses reported that a lack of basic skills in the workforce created problems for them in, for example, the introduction of new technology, product quality and productivity.

$\longrightarrow$

\section{Figure 1}

READING SKILLS IN CANADA

$\%$ of adults surveyed, 1989

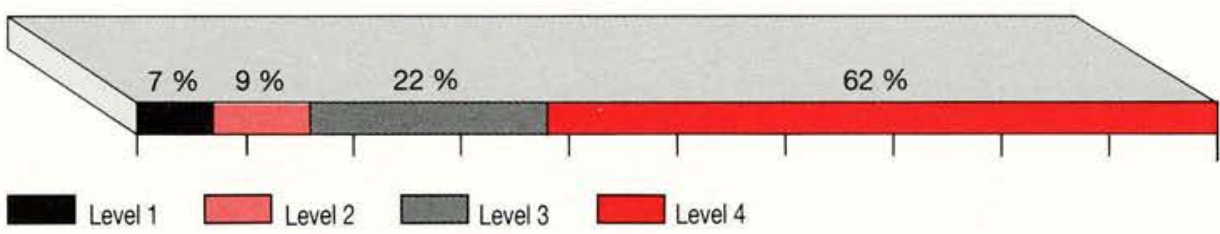

Can use printed materials for limited purposes, e.g., finding a familiar word in a simple text.

Can use simple texts for a variety of straightforward tasks, but tend to avoid situations requiring reading.

Source: Survey of Literary Skills Used in Daily Activities, Statistics Canada, Ottawa, 1990 


\section{Figure 2 \\ CANADA: LITERACY LEVELS BY FREQUENCY OF READING NEWSPAPERS, MAGAZINES OR BOOKS}

$\%$ of adult population, 1989

Yet attempts to quantify the economic costs have so far been 'guesstimates'; two recent ones for the United States showed a discrepancy of no less than $100 \%$ : $\$ 20$ billion and $\$ 40$ billion lost annually by businesses as a result of adult functional illiteracy. ${ }^{3}$ Firmer data is likely to persuade governments to give the problem a higher priority - especially in Europe and Japan, where recognition of a literacy problem has been slower than in the United States, Canada and Australia.

The most thorough national study to date, a survey of 9,500 Canadians carried out in 1989 by the federal government agency Statistics Canada, defined a number of different levels of an individual's literacy rather than looking for a single threshold (Figure 1). The headline that greeted the Canadian survey - ' $38 \%$ of Canadians Illiterate' - was probably misleading. But the fact that $38 \%$ of Canadians had reading limitations that could potentially affect their opportunities both inside and outside work was indeed disturbing.

The growth in demand for skills can explain what appears to be a drop in the standard of literacy.

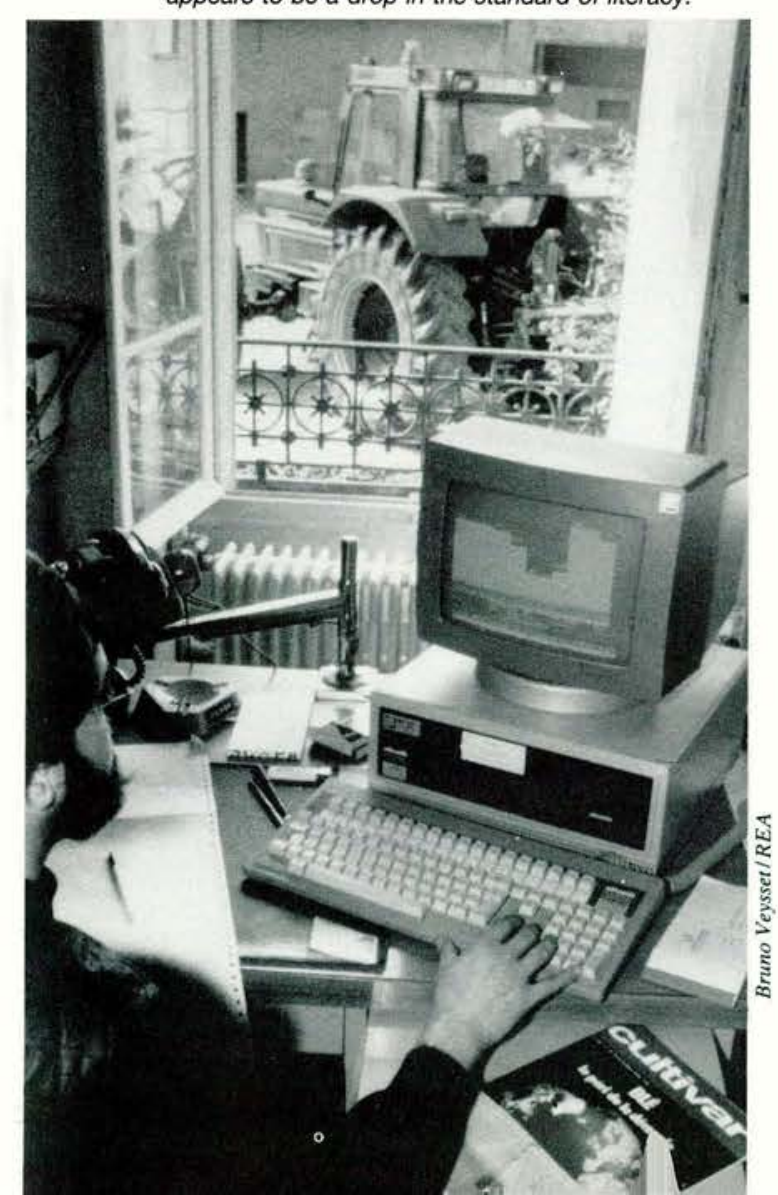

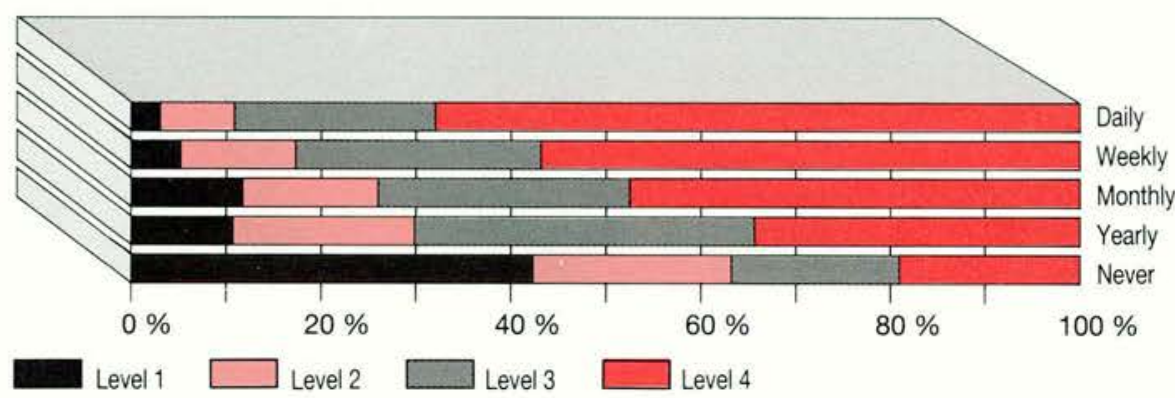

Source: Survey of Literary Skills Used in Daily Activities, Statistics Canada, Ottawa, 1990

There is no reason to think that Canadians are less literate than people in other advanced industrial countries. A similar survey in the United States found that whereas only $2 \%$ of people had no measurable literacy skills, between $60 \%$ and $90 \%$ were unable to carry out certain complex literacy-related tasks. Estimates in both Britain and France have put the number of illiterates in the millions. But in many countries there is still a cycle of ignorance about functional illiteracy: where there is no official recognition that it is a serious problem, there is also little money for research that might establish how serious it actually is. (The Canadian survey cost about $\$ 2$ million.) This is the situation both in countries like Germany, where the education system has always been held in high regard, and in the former Warsaw Pact countries, where official claims to have abolished illiteracy have never been properly examined.

But there may be short-cuts - ways of making reasonably reliable guesses at the extent and degree of adult illiteracy without going to the expense of full-blown surveys of skills. In conjunction with their direct research, the Canadians have been analysing to what extent other variables can be correlated with functional literacy. This is giving a better picture of which measures - such as educational attainment, reading habits and people's own assessment of their abilities - can best act as interim proxies for direct testing when estimating how many people are reading at each level. One of the strongest correlations is between literacy and the reading of books, though the link between literacy and general reading habits (Figure 2) is diluted by the much wider readership of newspapers. Since such behaviour varies across cultures, it would be dangerous to draw strong conclusions about illiteracy in a country from indirect indicators alone. But in combination with selective direct testing, they could reveal a lot.

\section{Remedial Measures}

Public education systems have always concentrated heavily on initial schooling, and measures to improve the literacy of adults remain patchy. Various recent initiatives to extend the remedial teaching of basic skills to adults have suffered both from uncertainties of funding and a still primitive understanding of what methods work. But one lesson that is slowly being learnt is that basic skills may most effectively be acquired in the context in which they will be used - that is, where the purpose is to improve performance at work, literacy may most easily be acquired in programmes based in the workplace.

Literacy schemes differ considerably from one country to another. In Canada and the United States public provision is devolved to the provinces and the states respectively, with the federal governments giving a weak lead (though recently there has been a surge of interest in the United States federal government). That has the advantage of allowing local experimentation, but local governments have difficulty finding consistent financial support from central authorities, and are not always willing to devote their own limited resources to such programmes. In Britain, too, the degree of commitment by central government has proved variable. A literacy cam-

3. Jonathan Kozol, Illiterate America, Anchor Press, New Jersey, 1985; Larry Mikulecky, 'Basic Skills Impediments to Communication between Management and Hourly Employees', Management Communication Quarterly, May 1990. 


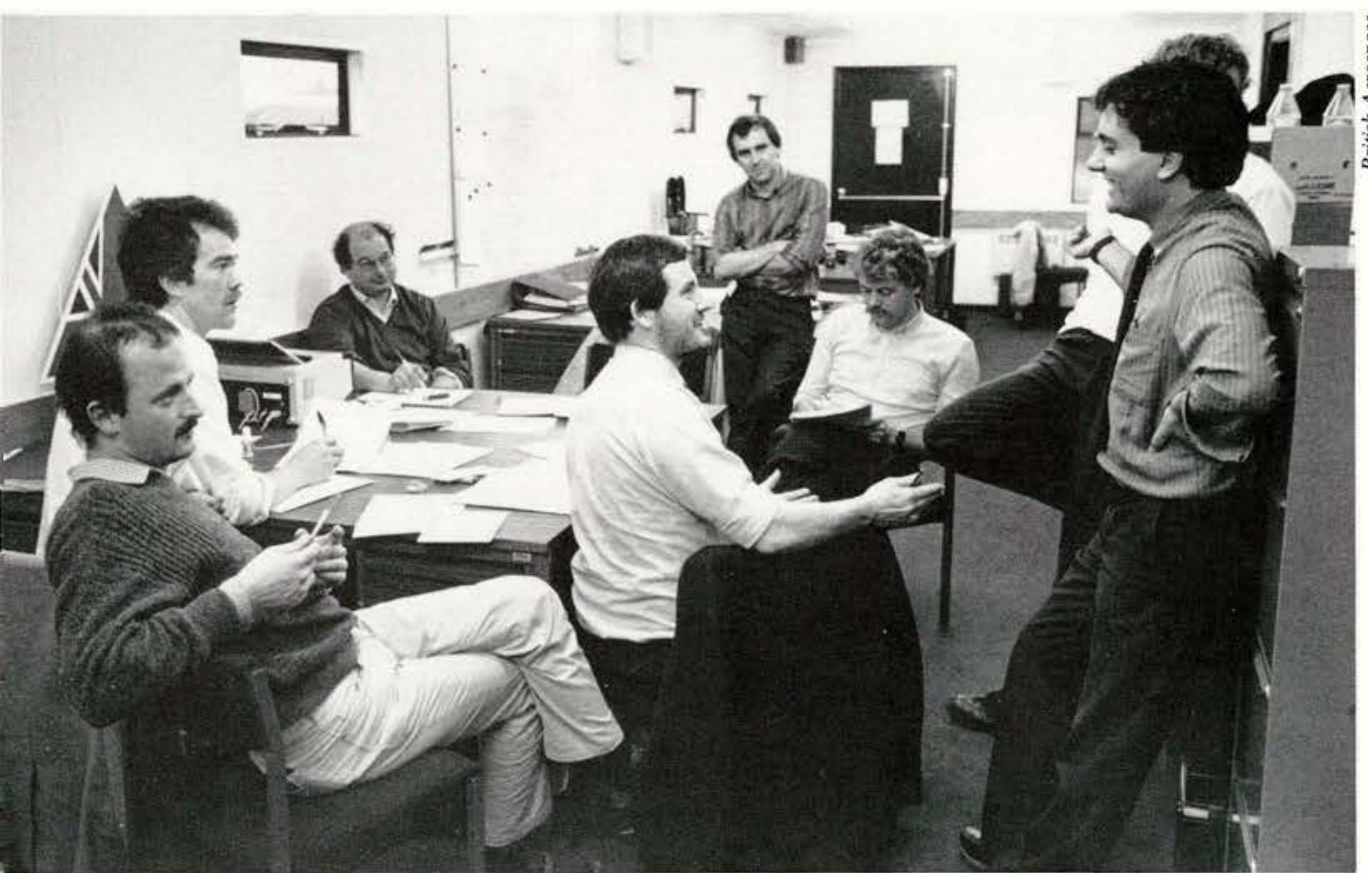

Basic skills are often most easily relearned where they will be deployed - in the workplace.

paign in the 1970 s was followed by waning national interest in the next decade. As a result, locally organised provision has emerged, run by the voluntary sector, which unfortunately suffers from sparse funding. Sweden, by contrast, has a highly developed adult education system, covering a wide range of the population, with structures that effectively reconcile national policy with local delivery. But it is not clear how well this system is oriented towards adults with basic literacy problems: there tends to be better access for the better educated, and there is no recognised distinction between remedial literacy training and other forms of adult education.

Remedial programmes linked with the workplace are developing unevenly in OECD countries. One of the most interesting findings of the OECD's analysis is that trade unions can play a beneficial role, largely by helping to make employees more enthusiastic about participating in programmes that they might otherwise find threatening. Ideally, work-based training programmes should be tied into

4. For example, Olivier Bertrand and Thierry Noyelle, Human Resources and Corporate Strategy, OECD Publications, Paris, 1988. the restructuring of work methods. To do so, firms may often have to fuse the updating of literacy skills with wider jobtraining - although it may not be possible to remove the necessity of complementary remedial programmes entirely.

Thus, for example, in the automobile industry in the United States General Motors and the United Auto Workers have co-operated to create a massive education centre for employees. With an annual budget of \$150-200 million it claims to be the largest privately funded education centre in the world. Many of the company's tradesmen in their forties and fifties require retraining, but are unable to benefit from the centre's courses because they have inadequate basic reading and maths skills. They are given remedial instruction by outside agencies to bring them up to high-school standard.

\section{Liferacy and the Adult Learner}

If literacy in the workplace means being able to use written materials to the standard required for one's job, studies of illiteracy will have to be closely related to the broader issue of adult education and training. OECD studies ${ }^{4}$ on the humanresource implications of technological change have concluded that a new kind of worker is required, one who uses literacy and other skills flexibly, to perform a wide range of tasks. Functional literacy thus becomes an issue not only for the (perhaps) 1 or $2 \%$ of people who cannot read at all or the 10 or $15 \%$ with severe reading difficulties, but for possibly a third of all adults who are unable to use reading materials in unfamiliar or complex situations. In a sophisticated modern workplace, all workers have to be able to confront the unfamiliar.

Now the well-researched subject of what skills are required in the modern workplace has to be translated into policies that make it more likely that adults will actually acquire them. There is still limited understanding about how, why or when adults learn. How: do they learn most effectively outside conventional classrooms, and how can teaching be adapted to their different learning styles? Why: what best motivates them to take up courses - for example, is the lure of higher pay more important than the prospect of increased responsibility at work? When: at what points in one's adult life is one most disposed to learn something new? The OECD's research on the adult learner is now focussing on these issues. But governments still have a strong tendency to look largely at their initial school systems in response to complaints about badly educated workers. Since over two-thirds of people who will be working at the turn of the century are already in jobs today, a strategy that focusses only on schools is bound to fail.

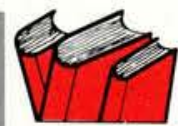

\section{OECD Bibliography}

- Lauren Benton and Thierry Noyelle, The Literate Worker - Adult Literacy and Economic Performance in Industrialised Nations, 1991

- Education and the Economy in a Changing Society, 1989

- Olivier Bertrand and Thierry Noyelle, Human Resources and Corporate Strategy, 1988. 


\section{An Energy Outlook for Non-0ECD Countries}

The Gulf crisis has provided energy experts with an opportune moment to examine long-term global energy outlooks, particularly in non-OECD countries. Political transition in the countries of central and eastern Europe and the emergence of environmental concerns have highlighted a number of trends in the production and consumption of energy which are likely to be reinforced in the next decade and beyond. The rapidly growing share of non-OECD countries in world energy demand has important effects both on world fuel supplies and on global energy/environment issues. ${ }^{1}$

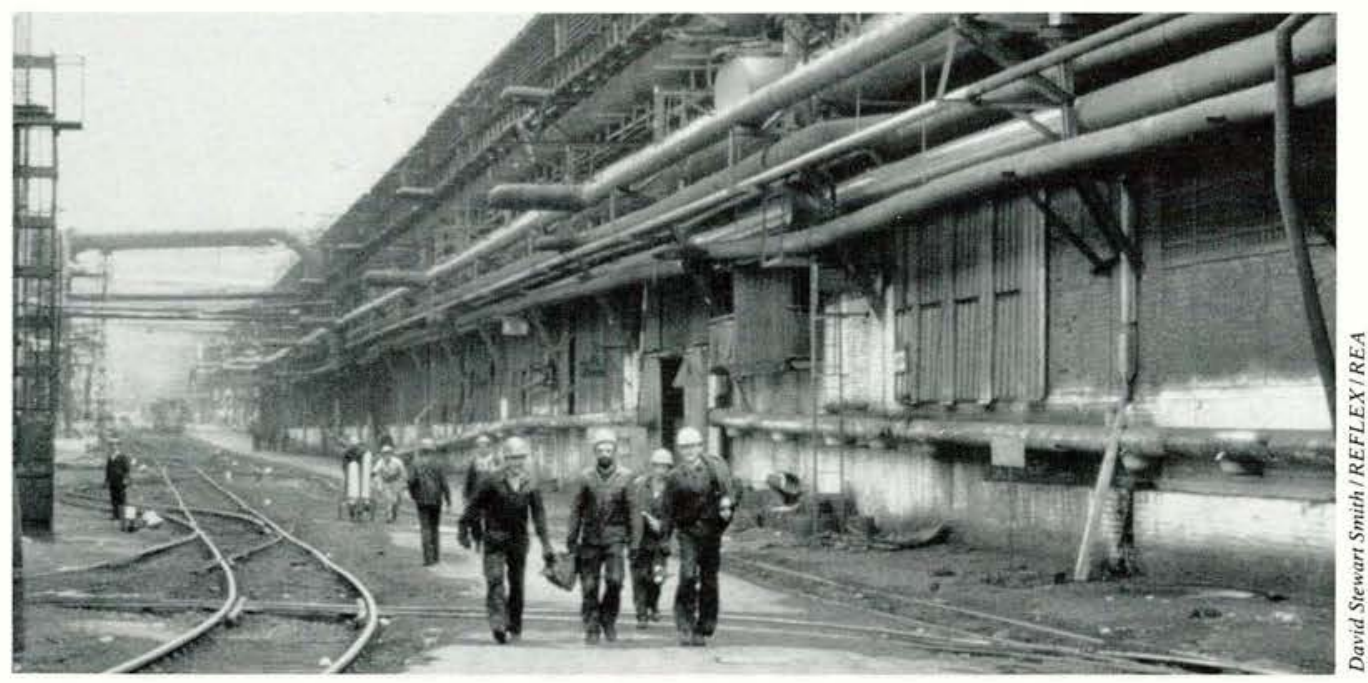

$\mathbf{T}$ he OECD countries account today for a diminishing share of world energy and oil requirements. In the developing countries, particularly in Asia and the Middle East, rapid industrialisation and the pressure for factory fuels have meant that their energy demands are growing swiftly. And in central and eastern Europe, too, political change is likely to lead to a surge in economic activity and in the demand for energy.

This growing demand is being met by a new set of suppliers. As the Soviet Union, worried about its own fuel requirements and accepting payment only in hard currency - is gradually losing its role as the dominant oil exporter to the central and eastern European economies in transition (CEEETs), they are turning to oil-rich developing countries which are more likely to accept payment in kind, in barter deals.

Coal and oil are still the most widely traded of the world's fuels. But political pressure for ones that are more environmentally benign makes natural gas an attractive alternative, and one to which many developing countries will increas- ingly turn, if deliveries can be competitively priced. Indeed, as environmental protection becomes a global concern, more resources are expected to be devoted to developing energy substitutes.

In 1971, non-OECD countries accounted for $37 \%$ of world energy requirements. By 1988 , the figure had risen to just over $51 \%$. In the most recent energy outlook $^{2}$ prepared by the International Energy Agency (IEA), the non-OECD share of world energy requirements is projected to rise even further, to $57.2 \%$, in the year 2005.

The Gulf crisis served as a reminder of the high degree of oil dependency throughout the world. Although the 4.3 million barrels a day of Iraqi and Kuwaiti production lost to the invasion were made up by increased output by other oil producers, and OECD countries suffered no shortfalls in supply, the crisis did hurt individual developing countries.

Mark Openshaw was, until recently, an analyst of energy issues in developing countries in the Office of Oil Market Developments in the International Energy Agency at the OECD.
At the time of the two oil shocks in the 1970 s, commodity prices were generally at a peak, leaving developing countries in a comparatively strong position. Today, prices of non-oil commodities are weaker, and those developing countries that failed to adjust their economies to world economic conditions in the 1980s now have more difficulty in adjusting them to basic energy price swings. $^{3}$

Thus, when the Gulf crisis occurred, a number of developing countries dependent on Iraqi and Kuwaiti oil suffered considerably from the ensuing UN embargo. In Asia alone, pre-crisis imports of Iraqi and Kuwaiti crude oil and products were estimated at 515,000 barrels a day. With the Iraqi invasion of Kuwait, much of that loss - especially in some of the least prosperous Asian countries - could not be recovered, despite increased production in

1. Energy in Non-OECD Countries, Selected Topics 1991, OECD Publications, Paris, 1991.

\section{Ibid.}

3. See Bernhard Fischer, 'From Commodity Dependency to Development', The OECD Observer, No. 169 April/May 1991. 
Saudi Arabia, the United Arab Emirates and Iran.

The Gulf crisis was also a reminder that the IEA simply cannot stray far from its fundamental purpose: ensuring energy preparedness for times of emergency. And now, indeed, on practically every continent - in Asia, Latin America and Africa - there are also regional emergency systems, through which oil-producing countries can come to the aid of their neighbours.

\section{Economies in Transition}

Energy supplies to the countries of central and eastern Europe were affected in 1990 by three simultaneous developments: the Gulf crisis, the collapse of the CMEA, and the decline of Soviet oil production. The first of these, as for developing countries, meant the loss of Iraqi and Kuwaiti oil supplies, and having to pay other oil suppliers in hard currency or by increasing the burden of their debt; it also deprived them of the ability to draw on Iraqi indebtedness to them.

The lack of market price signals and incentives in the centralised economic planning system meant that expanded production was never coupled with energy saving. As a direct result, energy intensity in the region is more than twice as high as in OECD countries. And there are, of course, accompanying environmental problems: levels of sulphur dioxide $\left(\mathrm{SO}_{2}\right)$ and solid particulate matter are about four times as high as in the OECD. ${ }^{4}$

The recent wave of economic liberalisation has altered the pattern of energy production and consumption. All countries are faced with the challenge of achieving economic growth while simultaneously slowing the rates of growth of their energy demand. High production costs will probably result in the closure of some mines in major coal-producing countries, and demand for oil and gas is likely to rise because of their less damaging effect on the environment.

With the erosion of the Soviet Union as the principal supplier of energy to the CEEETs, and in view of the paucity of oil and natural gas reserves in the area $(0.2 \%$ of proven world oil reserves, and $0.6 \%$ of

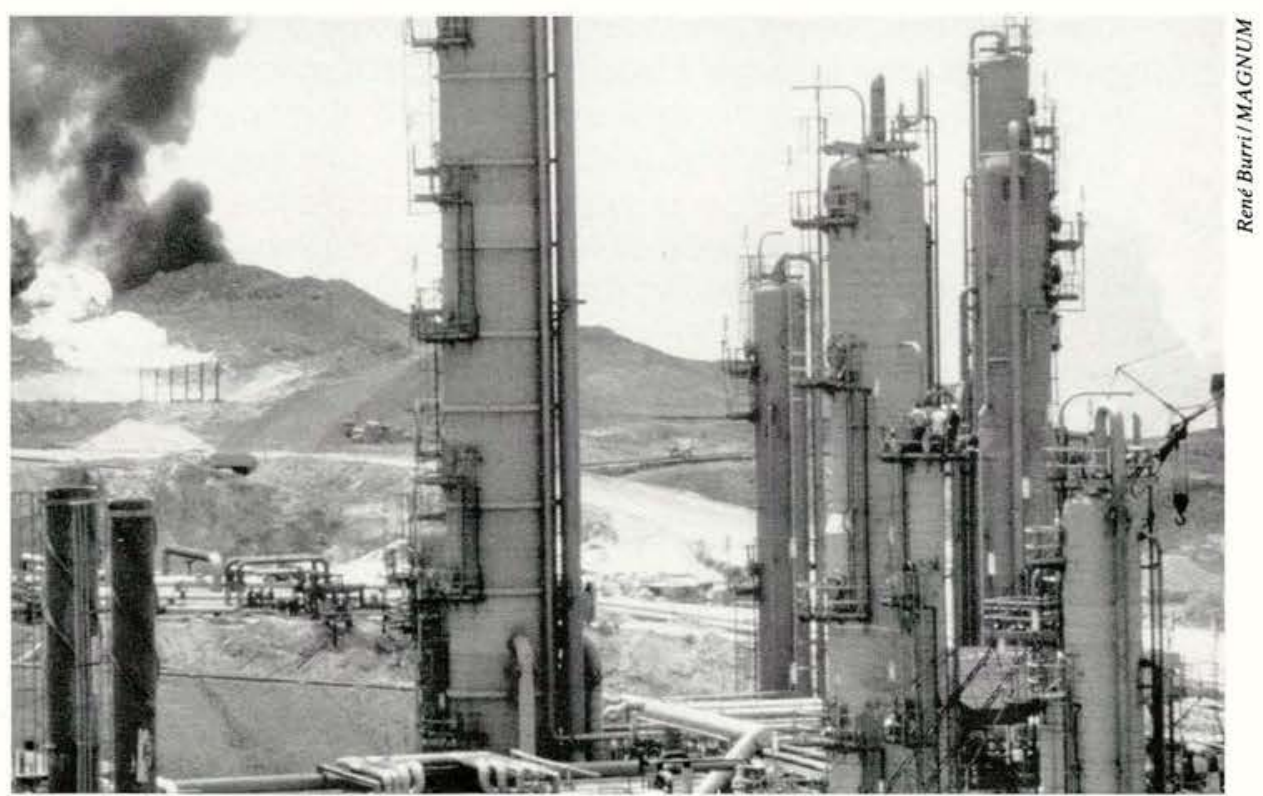

The Gulf crisis was a reminder of how much the world depends on oil.

proven world gas reserves), the CEEETs will import more oil and natural gas from international markets, and, at the same time, will attempt to rationalise their consumption. Moreover, not least on environmental grounds, they are likely to consume less of their considerable coal reserves. These account for $10 \%$ of world reserves of both hard coal and lignite. ${ }^{5}$

Over the past four decades, the six nonSoviet CEEETs - then Bulgaria, Czechoslovakia, the German Democratic Republic, Hungary, Poland and Romania - have maintained a high degree of energy selfsufficiency. In 1988, domestic production accounted for $75 \%$ of their total primary energy supply (TPES). In 1971, that figure had been $87.5 \%$. Coal provided $53 \%$ of the TPES, in spite of high production costs and difficult mining conditions.

Of the remaining TPES, oil provided $23 \%$ in 1988 . More than $80 \%$ of it was imported, nearly all from the USSR. Their own proven oil reserves are minimal. And today total deliveries from the Soviet Union are believed to be around 25\% below their 1989 volumes. By contrast, oil imports from non-Soviet sources have risen substantially, the main suppliers since the embargo with Iraq being Libya and Iran. That, too, has a cost: the switch to non-Soviet oil requires the modernisa- tion of their refining industries.

Natural gas, in 1988, provided $18 \%$ of the TPES of these six countries. Half of it was imported, with all imports coming from the Soviet Union. In recent years, domestic gas production in the region has dropped. The Soviet Union is still interested in supplying gas to the CEEETs, partly because it insists on being paid in hard currency, and partly because of the existing pipeline network.

Nuclear energy and hydro power contribute little to total energy supplies. Of the nuclear installations presently under construction in the CEEETs, there is increasing public concern about their reliability and safety. ${ }^{6}$ Hydro power provides almost as little electricity as does nuclear.

Over the years, CEEETs have devoted much of their capital investments to energy, with little regard to costs. Now the decrease in subsidies is driving costs upwards and fuelling inflation. A general liberalisation of all end-user prices, inter-

4. See Randolf Gränzer, 'Perestroika in Energy - The Soviet Union and Eastern Europe', The OECD Observer, No. 155, December 1988/January 1989.

5. See Stephen Perkins, 'Energy Policies for Poland', The OECD Observer, No. 170, June/July 1991.

6. See Jacques de la Ferté, 'A New Role for Nuclear Energy?', The OECD Observer, No. 170, June/July 1991. 


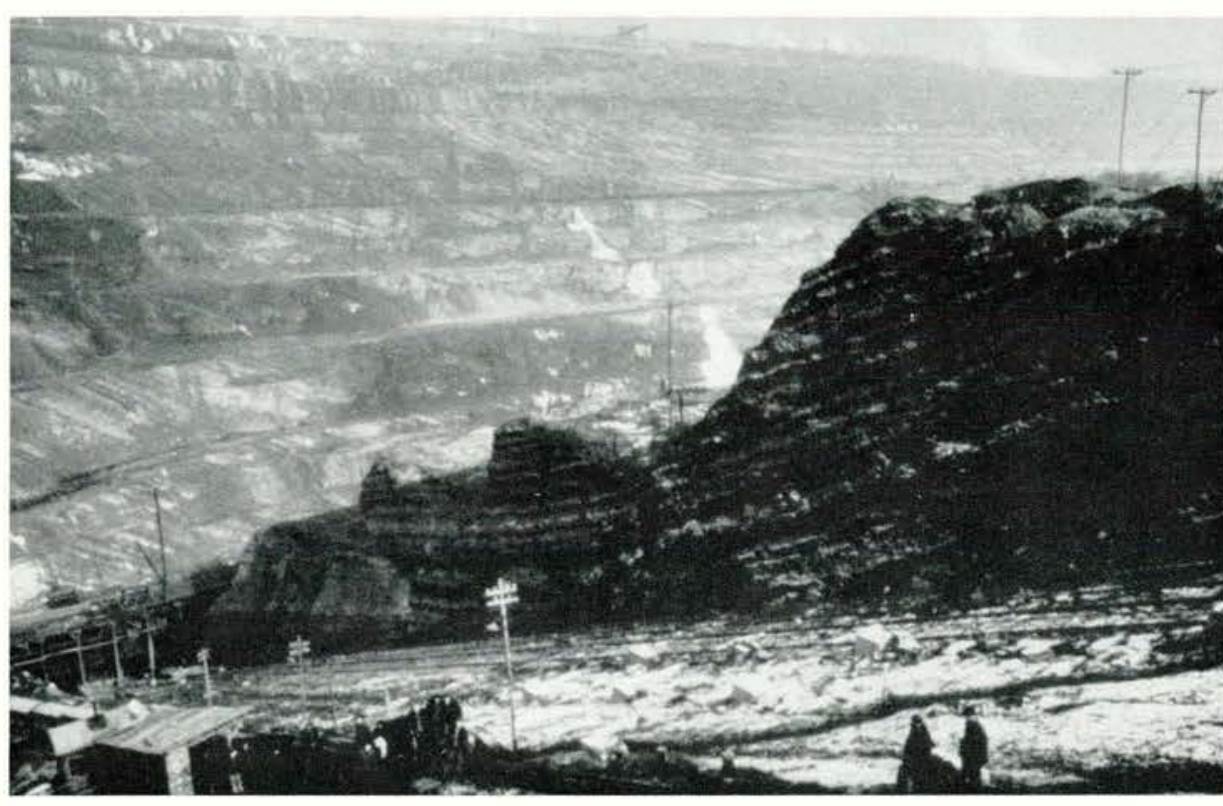

Over most of the past twenty years carbon emissions grew faster in China - at $5.7 \%$ a year - than anywhere else.

est rates and wages would help eliminate energy subsidies.

\section{Natural Gas in Developing Countries}

Once relatively neglected, natural gas has regained its appeal in the eyes of energy companies and policy-makers. The desire to make use of undeveloped resources has driven many countries to develop gas as an alternative fuel, and those that produce oil are anxious to use gas to release oil for export. Natural gas is a convenient substitute for imported oil and other fuels, and it can be more economically and environmentally attractive in power generation than its alternatives. Moreover, natural gas is, in some instances, an economic option in diversifying transport fuels.

For all of these reasons, the contribution of natural gas to world energy requirements is expected to grow from $20 \%$ in 1988 to $25 \%$ in 2005 . Growth is likely to be fastest in the developing countries, and demand there is expected to triple over that period.

Nearly half of the world's proven reserves of natural gas are located in developing countries. The Middle East accounts for nearly $30 \%$ of world reserves, a figure that has grown from a mere $17 \%$ in 1970 . The largest deposits are in Iran, the United Arab Emirates, Saudi Arabia and Qatar. In the three other regions - Africa, Asia and Latin America - proven reserves are comparatively low, each amounting to around national energy demands but not to allow exports on a large scale.

How widely are those reserves being used? According to Cedigaz, ${ }^{7}$ gross world production was 2,457 billion cubic metres in 1989. Developing countries produced $25 \%$ of that amount, the OECD countries $39 \%$, the Soviet Union $34 \%$, and the CEEETs the remainder.

Of the volume of natural gas produced, $2,030 \mathrm{bcm}$ was marketed, the rest being re-injected, flared or lost in some other way. As a rule, developing countries bring much less of their gross production to the market, because their losses are higher than elsewhere. Nonetheless, their share of world marketed gas production rose from only $6 \%$ in 1971 to $18 \%$ in 1988 .

Over the same period, gas production grew significantly in all the developingcountry regions: in Africa by an average of $14.4 \%$ per year; in Asia by $13.3 \%$ per year; in the Middle East by $8.4 \%$ per year; and in Latin America by $6.5 \%$ per year. These statistics compare favourably with an annual average of $3.3 \%$ for world gas $6 \%$ of the world total, enough to satisfy production, less than $0.1 \%$ in the OECD, $7.4 \%$ in the Soviet Union and $2.2 \%$ in the CEEETs.

But a number of constraints - sometimes in combination - have prevented a steeper rise in gas production: the absence of a domestic market, the high costs of transport, difficulties in financing the development of fields, and monopolies by state-owned companies.

The outlook for gas production in developing countries is nonetheless an optimistic one. Plans are underway in many countries to upgrade and increase capacity. The IEA forecasts that marketed production of natural gas in developing countries will rise from 290 million tons of oil equivalent (MTOE) in 1988 to 886 MTOE in 2005, an annual growth rate of $6.8 \%$.

The consumption of natural gas in developing countries is relatively low today, but has grown at an increasingly faster rate throughout the 1970s and ' 80 s. Demand from developing countries is expected to grow at an annual average of $7.5 \%$ from 1988 to 2005 . The biggest increases will occur in the major gas and oil producing countries in the Middle East. Much of that increased demand will go towards the generation of electricity.

\section{Energy and the Environment}

There are, broadly speaking, two types of energy/environment issues: the more conventional and better-known nitrous and sulphurous pollutants, and the growing concentration of carbon dioxide $\left(\mathrm{CO}_{2}\right)$ and other greenhouse gases. As concern over environmental hazards increases, energy policies must improve the environmental impacts of energy production and use. At the same time, environmental concerns ought not to frustrate the process of economic growth.

One of the better known and most publicised of the 'conventional' energy/environment problems is that of oil spills. Public concern has risen in recent years, resulting in the formulation of contingency plans in Latin America, the Middle East and south-east Asia. In addition, a confer-

7. Natural Gas in the World, 1990 Survey, Cedigaz, Rueil-Malmaison, 1990. 


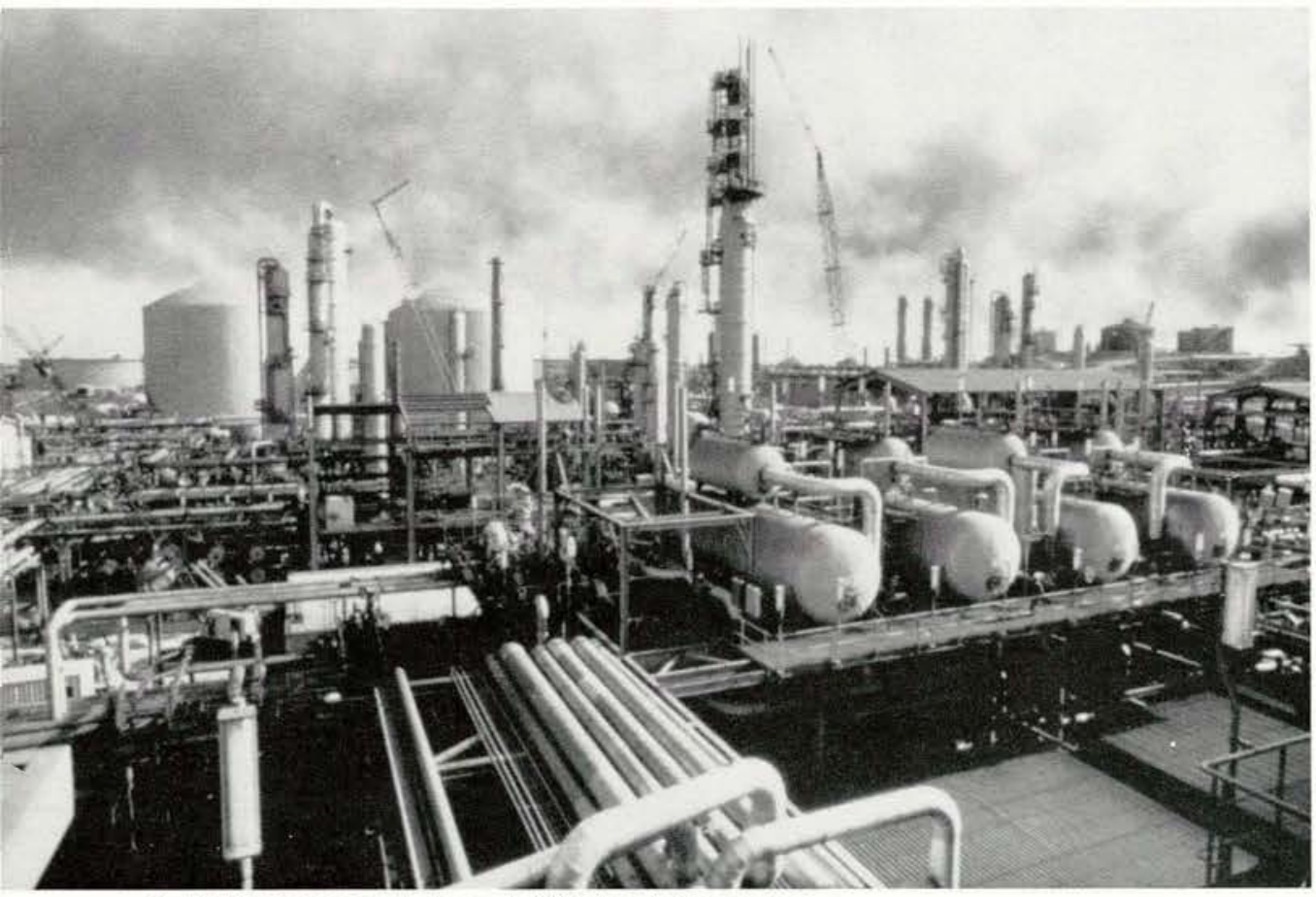

The Middle East accounts for nearly $30 \%$ of world gas reserves.

ence of the International Maritime Organisation (IMO) agreed in November 1990 on an international convention on ways to deal with oil pollution from ships and oil production.

The newer of the two types of environmental hazard is the emission of greenhouse gases - a phenomenon subject to continuing scientific debate and controversy. There are five significant types of these gases: $\mathrm{CO}_{2}$, methane $\left(\mathrm{CH}_{4}\right)$, nitrous oxide $\left(\mathrm{N}_{2} \mathrm{O}\right)$, tropospheric ozone $\left(\mathrm{O}_{3}\right)$ and chlorofluorocarbons (CFCs). Their sources are both natural and man-made, with the energy sector believed to account for the largest share of those derived from manmade sources. Energy policy must, therefore, play an integral part in devising appropriate responses to concerns over global warming.

$\mathrm{CO}_{2}$ is estimated to contribute $71 \%$ of the share of the greenhouse effect that can be ascribed to human activity. And three-quarters of this amount is emitted by the energy sector. Since 1973, energy-

8. See Randolf Gränzer, 'The Energy Impediment to China's Growth', The OECD Observer, No. 157, April/ May 1989. related $\mathrm{CO}_{2}$ emissions in non-OECD countries have increased much more rapidly than in the OECD area - at an average annual growth rate of $3.5 \%$, compared to $0.33 \%$ in the OECD countries. As a result, the non-OECD share of world $\mathrm{CO}_{2}$ emissions appears to have risen from $44 \%$ in 1973 to $55 \%$ in 1988 .

Non-OECD countries may thus be contributing as much as OECD members to the problem of global carbon dioxide emissions. Their share is expected to grow, since they have a higher growth rate in incremental consumption of hydrocarbons, both liquid and solid. By 2005, their volume of global carbon emissions is expected to reach $59 \%$. The largest proportion of non-OECD emissions currently originates in the USSR (30\% in 1988) and China (19\%). China had the highest growth rate in carbon emissions between 1973 and 1988: an average of $5.7 \%$ per year. $^{8}$

The share of coal in energy-related $\mathrm{CO}_{2}$ emissions in the non-OECD countries in 1988 was $44 \%$. Again, the USSR and China provided $60 \%$ of that amount. Oil, natural gas and traditional fuels accounted for
$29 \%, 15 \%$ and $12 \%$ respectively.

In sectoral terms, industry is by far the largest contributor to $\mathrm{CO}_{2}$ emissions, generating $53 \%$ of them in 1988 . Transport contributed another $16 \%$.

One possible response is fuel substitution, and efforts to switch from coal and oil to other less polluting fuels will probably be pursued. In a large number of developing countries, for example, there are the hitherto untouched reserves of natural gas that can be tapped. But that will be costly, and administrative and policy impediments in a number of countries often prevent foreign companies from participating in the development of these resources. Another policy response is to improve efficiency in the use of all energy fuels.

In most developing countries, the ability to tend to environmental demands is contingent on economic performance. Simultaneously, many major environmental problems are associated with a lack of economic development. Ironically then, developing countries will have to ensure continued economic growth, not only for its own sake but as a condition for arresting environmental deterioration.

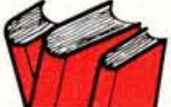

\section{OECD Bibliography}

- Energy in Non-OECD Countries, Selected Topics 1991, 1991

- Annual Oil Market Report,

forthcoming 1991

- Stephen Perkins, 'Energy Policies for

Poland', The OECD Observer, No. 170, June/July 1991

- Jacques de la Ferté, 'A New Role for Nuclear Energy?', The OECD

Observer, No. 170, June/July 1991

- Bernhard Fischer, 'From Commodity

Dependency to Development', The OECD Observer, No. 169, April/May 1991

- Randolf Gränzer, 'The Energy Impediment to China's Growth', The OECD Observer, No. 157, April/May 1989.

- Randolf Gränzer, 'Perestroika in Energy - The Soviet Union and Eastern Europe', The OECD Observer, No. 155, December 1988/January 1989 


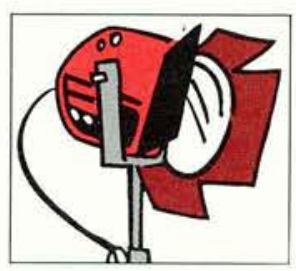

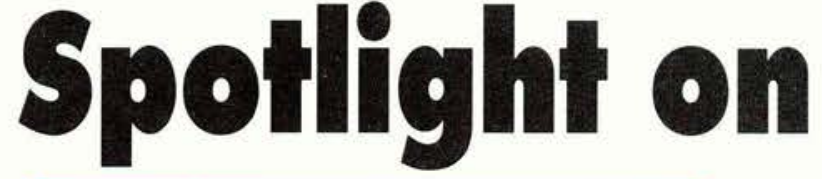

Paul S. O'Brien and Niels Westerlund
C erman unification has not had the consequences initially foreseen. A year after economic and monetary union, it is clear that the adjustment in the five Länder set up in the former GDR has been much more painful than expected, while the economy of western Germany is so far coping well with a potentially very destabilising shock. ${ }^{1}$

The extreme rapidity with which unification took place - dictated by both political considerations and the necessity of grasping immediately the historic opportunity that the international situation then offered - has had both beneficial and adverse effects on the initial phase of the economic integration and adjustment process. In western Germany, which accounts for more than $90 \%$ of all German GNP, growth has accelerated without rekindling inflation. In the eastern part, in contrast, output has plunged and unemployment (both official and disguised) has surged.

The rapidity with which the unification of the two Germanies took place has given the former GDR advantages over the other central and eastern European countries that have also embarked upon a transition to the market economy. But at the same time it has subjected it to constraints not experienced by the other countries. On the basis of a preliminary assessment of this exceptional year, the OECD has identified measures required to speed up the recovery of the new Länder and has set out macro-economic policy goals that policy-makers should pursue if they wish to preserve the solid prosperity of the western Länder and speed up the convergence in standards of living between the two parts of Germany.

Paul S. O'Brien and Niels Westerlund specialise in the economies of Germany and Austria in the Country Studies and Economic Prospects Branch of the OECD Economics and Statistics Department.
In four important spheres the former GDR embarked upon the transition to a market economy in much more favourable conditions than the other centrally planned economies.

First, in monetary matters, the replacement right from the outset of a nonconvertible currency by one of the

\section{INDICATORS}

\section{GNP}

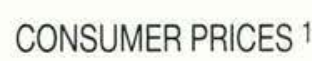
change from previous year

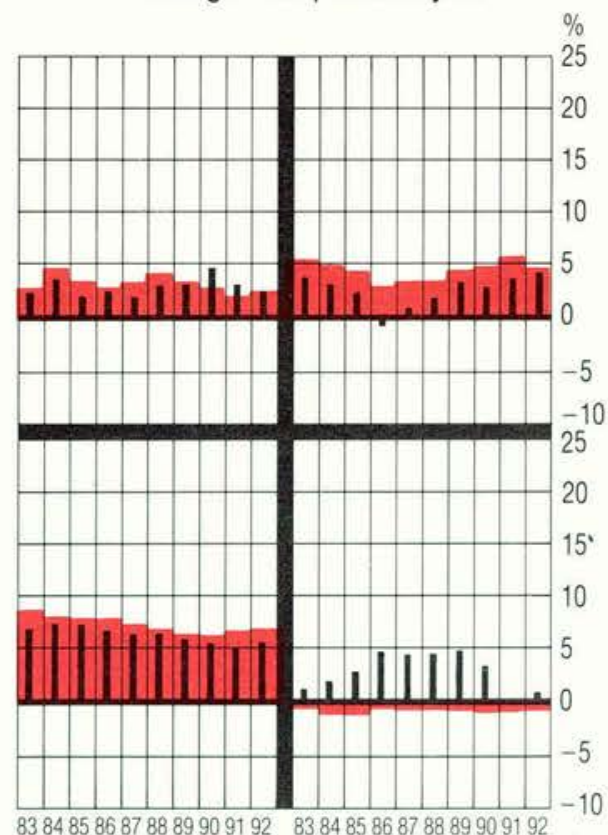

UNEMPLOYMENT 2 CURRENT BALANCE

$\%$ of labour force $\%$ of GNP

\section{Private consumption deflators.} 2. National definitions.

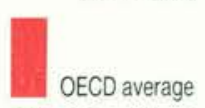

Note: All these figures are for the former Federal Republic of Germany, with the exception of those for the Current Balance from July 1990, which include the former German Democratic Republic. strongest and most stable currencies in the world, managed by a central bank of high international repute, gave the country immediate and direct access to world financial markets.

Second, the adoption of a tested legal and institutional framework enabled the former GDR to avoid a protracted debate on its institutional framework, the outcome of which would have been uncertain; it has also been able to benefit from the technical assistance of people who speak the same language and share the same cultural background. Third, massive financial help was provided. Fourth, direct access to western markets and products has virtually wiped out the monopoly power of eastern German producers.

But the exceptional advantages that unification bestowed on the former GDR have been accompanied by disadvantages. Among them are the relatively weak incentives to adjust to the new environment, due to the provision of a social safety-net designed for a high-income country and support for loss-making firms; the adoption of western Germany's regulatory framework also meant the adoption of rigidities and cumbersome procedures, which has impeded the take-off process; and, above all, the fact that large parts of the tradable goods sector have been made uncompetitive by the widening gap between production costs in eastern Germany and world prices.

This rapid worsening of the situation can be ascribed to the one-to-one conversion of eastern German wages at monetary union, and to the fact that wages there have been rapidly catching up with those in western Germany. The price-cost scissors effect has been accompanied by

1. OECD Economic Surveys: Germany, OECD Publications, Paris, 1991. 
other developments that have been extremely prejudicial to a smooth transition in eastern Germany. For example, the free flow of consumer goods from the West has caused demand for GDR-made products to collapse. More recently, the traditional export markets of eastern German firms have shrunk dramatically as a result of the internal difficulties of the CMEA countries and their shortage of hard currency.

The scope for restructuring has been reduced by the reluctance of banks to grant loans in the absence of a reliable valuation of the assets and liquidity position of eastern German firms. The numerous outstanding property claims have obviously not helped either. Furthermore, the administration in the former GDR has been slow to translate policy decisions into effective action, and to channel federal government funds into worthwhile projects. Lastly, the run-down condition of transport and telecommunications infrastructure and the lack, or poor quality, of services, have obviously not been conducive to the emergence of private enterprise and creativity.

The upshot was that six months after economic and monetary union was introduced unemployment had risen from 100,000 to 650,000 (plus 1.8 million parttime unemployed), unit labour costs had increased by $50-60 \%$, and the general level of activity had fallen by some $20 \%$ or more.

The contrast is striking when the situation is compared with that in western Germany. The massive financial transfers to the former GDR have galvanised activity in western Germany because they have been used primarily for financing purchases of western German products. As this finance was not raised through tax increases or public spending cuts but was borrowed in the capital markets, domestic demand was given a strong boost. It is estimated that unification added $1 \frac{1}{2}$ percentage points to GDP growth in 1990 - bringing it up to $4 \frac{1}{2} \%$ - and that it should add a further 1 percentage point in 1991 .

This high degree of activity has not so far resulted, as had been feared, in very significant inflationary pressures, although the level of wage inflation is causing some concern. The additional demand generated by the former GDR has been for consumer goods, the production capacity for which was less tight, for western German export products at a time when foreign markets for them were contracting, and for foreign products. For the rest, the high rate of investment in recent years and the influx of labour from eastern Germany permitted the increase in capacity required to meet demand. And the steep reduction in the German trade surplus made it possible to avoid a surge in prices.

Against this background, and in particular in view of the much higher-than-expected financial cost of unification, two main questions can be asked: what additional or remedial action is required to speed up the recovery in eastern Germany? How can such support remain compatible with the maintenance of a stable financial environment and strong economic growth in western Germany?

\section{Improvements in Four Spheres}

Since the principles of the policy being implemented in the former GDR are based on the creation of a competitive environment, private ownership, the autonomy of labour-market partners and the achievement of a high degree of social and regional equity, improvements should be made in four spheres: privatisation, labour-market flexibility, the use of subsidies and the creation of new enterprises.

The aim of privatisation is to improve economic efficiency and productivity. But as the implementation of the privatisation programme for some 9,000 large state enterprises has had a slow start, the factors that have held up the process had to be examined. There are several. First and foremost, the Unification Treaty provided for restitution of property rather than compensation for former owners. The government has since allowed the Treuhandanstalt to sell enterprises or land even if there is still a claim for restitution pending; but a purchaser who does not have a 'title' to ownership must come up with a restructuring plan that safeguards or creates more jobs than would be the case if the enterprise were returned to its former owners.

Second, for a long period there was an emphasis on preserving enterprises in their original form; this constraint limited the participation of capital markets and some unincorporated entrepreneurs in the privatisation process. The legislation introduced recently to facilitate the break-up of large enterprises is therefore welcome. But the mechanisms for transferring ownership should continue to be diversified to include management buy-outs, giving employees preferential access to shares, or sales by auction. One factor that particularly deters potential investors is the uncertainty surrounding the size of company debts and, in the case of the sale of part of a company, the allocation of the debt between its various parts. The government still prefers a case-by-case approach, which slows down the privatisation process.

Another financial burden for potential purchasers of companies are previously negotiated social plans that place restrictions on redundancies. Although such agreements are obviously reflected in the selling price of companies, this is not the most efficient way of sharing the burden of restructuring. Indeed, if the selling price of privatised companies is simply to reflect their potential turnover, they should be sold free of all debt and obligations contracted under previous ownership.

The lack of labour-market flexibility is another factor that impedes the restructuring of the former GDR. There is an enormous need for wage differentiation between companies and between skill levels. The introduction into the former GDR of western German bargaining practices has meant that strong unions pushing for wage equalisation have found themselves face to face with weak management inherited from the old system which is usually unaccustomed to defending the financial interests of a firm that does not belong to it or in which it has no stake. Managers seated at the bargaining table must therefore have a personal interest in the profitability of their firms, and the bargaining process should be decentralised as much as possible.

One of the most difficult problems posed by the transition to a market economy is that of the use made of subsidies. With a major imbalance between supply and demand, it was understandable that the government decided to keep lossmaking firms afloat by means of liquidity 
credits, and to encourage their workers to retrain within their old firms via short-time work and financial assistance. But these practices inevitably perpetuate a suboptimal allocation of resources and are unlikely much to improve the mediumterm employment outlook.

Those firms that seem unlikely to be credible candidates for privatisation should be allowed to stay in business only if their sales revenue covers at least material inputs and maintenance, and most of their wage bill. And no money should be made available for capital renewal or financing rehabilitation programmes unless there is a reasonable chance that they will be profitable. But in any case, it is essential that the assistance should provide an appropriate incentive to both management and labour.

Although they are directed essentially to the least productive uses of resources, the various support measures do perform the essential function of supporting eastern German living standards during the transition period. In fact, given the enormous gap that has opened between eastern German wages and productivity levels since unification, there will probably be a strong demand for financial support for employment during the difficult period of restructuring and adjustment to a new competitive environment. The authorities will therefore have to choose between terminating existing programmes, renewing them again, or replacing them by other forms of job support. In these circumstances, one way of meeting this commitment but with fewer distortions and fewer problems of moral hazard would be, for example, to replace current subsidies by a direct employment bonus that would vary according to the difference between the wage actually paid by a firm, and the basic wage in that industry in western Germany. This would give firms and their managers an incentive to resist wage increases, and would introduce more effective competition between firms in the former GDR.

In the longer term, the creation of new firms seems the surest way of facilitating structural adjustment and reducing unemployment. But until now this process has been held back by the lack of premises and construction sites, and by numerous bureaucratic and economic barriers. One way of promoting the creation of small and medium-sized enterprises in the building trades, for example, would be to reinvigorate the housing market by selling state-owned dwellings to their occupiers on preferential terms. The key question of the shortage of capital is largely ascribable to the poor condition of transport and telecommunications infrastructure. The best way of activating the vast amount of infrastructure investment required would be to speed up deregulation and to improve transparency.

Tax reliefs and concessional financing for investment can also be a means of attracting capital. But although they may be warranted at the start of the process, care must be taken that they do not introduce longer-run distortions in the structure of the capital stock.

\section{The Impact on Two Major Balances}

The supply-cum-demand shock of unification is having major macro-economic consequences. Two macro-balances have been particularly affected: the current external balance and the public sector borrowing requirement. The reduced external surplus could even turn into a deficit. But besides the fact that the narrowing of the current account surplus is a step in the direction of the more balanced world economy desired by Germany's partners, it does not, in fact, signal any loss of competitiveness but merely a voluntary rechannelling of trade flows to meet demand from eastern Germany. Similarly, the large public sector deficit does not necessarily indicate a loss of fiscal control, particularly as Germany's public debt is not very high and there is a large potential for growth in eastern Germany.

Nonetheless, the authorities must keep a close watch on the financing of the public sector given that in 1990 and 1991 recourse to the capital market served essentially to finance consumption rather than investment. High government borrowing puts upward pressure on interest rates and tends to crowd out private investment. Furthermore, a steep increase in interest expenditure reduces the amount of leeway in fiscal policy. Lastly, fiscal restraint is important for investors' confidence and for stability in bond and foreign exchange markets.

Consolidation is therefore required, preferably through spending cuts concentrated in the western part of Germany. Subsidy cuts, which up to now have been much too timid, should be increased. Yet the deficit should not be reduced too rapidly, since this would mean that the present generation would be bearing an over-large share of the costs of adjustment: the costs should also be borne by the future generations who will reap the real benefits of unification.

To finance the additional spending in the former GDR and the contributions to the cost of the Gulf war, in March 1991 the German government decided to raise direct and indirect taxes, the increases in direct taxes being only temporary. The increases in indirect taxes do not facilitate the task of the monetary authorities since, by raising the level of prices, they may affect expectations in both labour and financial markets. Given the importance of restraining the growth of the M3 monetary aggregate, the Bundesbank, which has also been faced with a weakening of the Deutschmark, has maintained a tight monetary policy. If inflationary expectations deteriorate any further, either because of imported inflation or as a result of wage increases, continuing restraint may be necessary.

In sum, given the stretched resources of western Germany and a continuing deterioration in eastern Germany, the German authorities must concentrate their efforts in two directions: first, they must maintain domestic stability and the confidence of the international markets by following a firm and steady policy of budget consolidation; second, the resources channelled to the eastern part of Germany must be used in the best possible way by enhancing the efficiency and credibility of existing programmes.

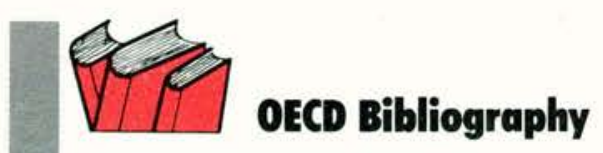

- OECD Economic Surveys: Germany, 1991. 


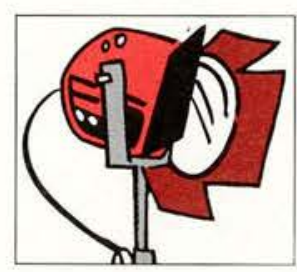

Spotlight on France

Peter Jarrett and Marie-Odile Louppe

$\mathbf{T}$ he French economy has performed well in recent years, with activity relatively buoyant, internal and external deficits remaining within manageable limits and inflation kept under tight control. ${ }^{1}$ Real economic growth was substantial until mid-1990. While activity has stagnated since the onset of the Gulf crisis, the conditions are in place for a recovery in the second half of this year. Inflation has been broadly stable despite the recent oil price increase, and the differential with Germany has been narrowed. Job creation in 1990 was in excess of $1 \%$ for the second year in succession. The current account of the balance of payments has continued to be only slightly in deficit, while the basic balance remains in equilibrium. Excluding debt forgiveness the budget deficit has been kept on a downward path. Finally, reflecting investor confidence in the strong-franc policy, interest-rate differentials against Germany have continued to ease and had been eliminated for shorterterm instruments at the beginning of the second quarter.

The one blot on the government's economic record is unemployment which, at over $9 \%$, remains comparatively high. That is because the upturn in the economy came later in the 1980 s and did not create as many new jobs as in other countries but was accompanied by exceptionally high productivity growth, partly because of inflexibility in the labour market. Yet that is only one of a number of structural rigidities inhibiting the efficiency of the French economy. Other problem areas include the social security system and competition policy.

\section{The Unemployment Problem}

France has experienced persistently high unemployment, and many of the jobless have been without work for a long time (three years or more), especially older workers, the young and the unskilled. At the same time, skill shortages are blamed for an acceleration in real wage increases.

After a lengthy period of wage moderation, it appears unlikely that labour costs

Peter Jarrett and Marie-Odile Louppe specialise in the economies of France and Portugal in the Country Studies Branch of the OECD Economics and Statistics Department. are excessive overall. But the strong concentration of joblessness among unskilled workers - with an unemployment rate in 1989 double the average national rate suggests that for these employees total compensation exceeds equilibrium levels, thereby discouraging hiring. This situation may be explained in part by the national minimum wage (SMIC). With the substantial increase in its value at the beginning of the 1980 s, the cost of employing low-skilled workers may have gone beyond their marginal productivity and the gap between the SMIC and the average wage narrowed considerably. Faced with this development a variety of measures (traineeships, reductions in social-security contributions) were introduced which involve levels of compensation de facto below the SMIC. These measures have contributed to the

\section{INDICATORS}

\section{GDP}

CONSUMER PRICES 1

change from previous year

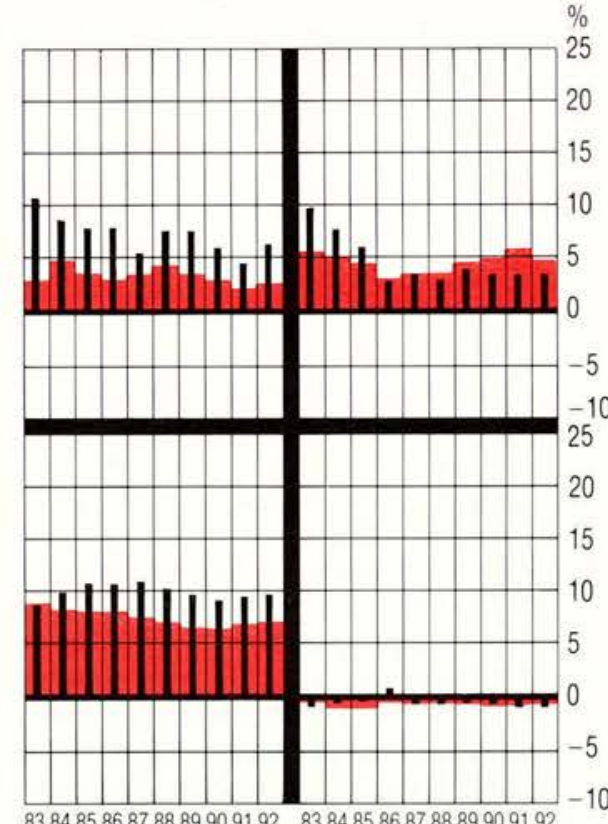

8384858687888990919283848586878889909192

\section{UNEMPLOYMENT 2 \\ CURRENT BALANCE}

$\%$ of labour force

$\%$ of GDP

1. Private consumption deflators

2. National definitions.

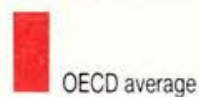

significant fall in youth unemployment rates in recent years. Yet given their implications for the public finances, they are a second-best solution.

The government has also sought to bring people on the fringes of society back into the labour market by establishing a guaranteed income for those prepared to take the necessary steps to reintegrate themselves into the work force. Thus far, the programme has proved rather expensive, with relatively little success in putting those in the target groups back to work.

A more effective approach might be to raise the productivity of lower-skilled workers by better education and training, whether first-time training for the young to give them the skills demanded by today's labour market or improved retraining programmes for adults. The authorities have recently begun to address the problem by making education one of the priority spending areas in the budget as well as by instituting a system of personalised training from which nearly 200,000 participants have benefited since its inception in 1989.

\section{Reforming Social Security}

The reform of the social security system remains high on the government's agenda. The authorities have not succeeded in curbing the growth in the volume of social spending, which actually increased from an average annual rate of $2.7 \%$ in the three years to 1987 to $3.4 \%$ in the most recent three-year period. The main component, the régime général, is in substantial deficit, as the structural surpluses on industrial accidents and family allowances have levelled off and the chronic deficits on health and retirement pensions have widened.

The main area of rapid recent increases is health spending, with outlays now absorbing $8.1 \%$ of GDP, as against $6.8 \%$ in 1980. Some moderation occurred in 1990 , partly because of a prolonged strike by some administrative staff but also as a result of a reduction in VAT on medicines from $5.5 \%$ to $2.1 \%$, cuts in the margins of pharmacists and suppliers of specialist

1. OECD Economic Surveys: France, OECD Publications, Paris, 1991 
services, and lower fee increases for medical practitioners. It is also planned to cease reimbursing non-therapeutic treatments (which costs FF 14 billion a year) and to increase the managerial autonomy of hospital administrators. Nevertheless, the focus of such measures has been on limiting supply with little in the way of demand-restraining reforms.

The financial situation of the retirement account is also deteriorating, and the only measure taken so far to contain the growing burden has been to index pensions on price rises rather than wage increases. On present demographic trends, the situation will continue to worsen gradually up to the year 2005 and will deteriorate rapidly thereafter, with the ratio of retired people to those in work reaching 0.78 by 2040 , compared to 0.45 now. To finance the present level of benefits, contribution rates would have to be stepped up, from $16.3 \%$ in 1985 to $22 \%$ in 2005 and nearly $40 \%$ by 2040 .

A viable system will certainly call for an increase in contribution rates over the long term, but other measures could limit the rise. For example, extending working lifetimes by 1.5 years (thereby effectively raising the retirement age to qualify for a full pension) would enable the rate of contributions to be stabilised up to 2005 and its increase reduced by two or three points thereafter, but a reduction in the value of benefits may also be necessary. To smooth the process of adjustment, reserves could be constituted by increasing contribution rates beyond those required to balance the system in the short term. The entire question has been recently discussed in a government white paper, and the authorities hope that a wide-ranging discussion will allow legislation with a view to substantial reform to be introduced by the spring of 1992.

\section{Improving
Compelition Policy}

Up to the early 1980 s, economic policy was distinctly interventionist, based on promoting 'national champions', assisting sectors in difficulty, and 'reconquering the domestic market' through the wave of nationalisations in 1982. Since then, however, the authorities have reduced the extent of their intervention in the economy and endeavoured to increase competition in sectors sheltered from foreign competition. Subsidies to declining industries have been reduced, since they were seen to delay rather than promote structural adjustment. In 1987-88 some stateowned enterprises were privatised where there was no strong justification for public ownership, and government is now interfering less in the management of companies remaining under state control. As of recently, partial privatisations are again to be permitted, provided they form part of a change in overall business strategy.

Barriers to entry are still common in French industry. There has been a general tendency to attach insufficient importance to the welfare of consumers and too much to producer interests. A prime example is in the automobile industry, where imports of Japanese cars are still limited to $3 \%$ of the market. That measure has contributed to higher car prices and longer design and product-development cycles. Moreover, imports from Japan have been replaced by imports from other countries, and the Japanese have stepped up their penetration of other less-protected markets at the expense of French exporters.

Nonetheless, various regulatory barriers have been or are in the process of being lowered within the framework of EC integration, especially in the road haulage, domestic air travel and telecommunications sectors. The public monopoly on air services to the overseas départements was liberalised in 1987, and, in accordance with EC policies, the authorities have undertaken to accelerate the introduction of competition on domestic and international routes as well. Segments of the telecommunications market, moreover, have been excluded from the state's 'natural monopoly'.

Yet many sectors, fee-earning trades and professions remain regulated. Public services are often provided by only one supplier, although there is some 'ex ante' competition in the tendering procedure for selecting the supplier. Television and radio stations require prior authorisation from the relevant authority, and licenses are needed to engage in a host of business activities, ranging from taxis to funeral services to pharmacies. Similar regulations govern the medical, legal and some technical professions.

Simultaneously with the price liberalisation of 1986, competition legislation was reformed, and a strong and independent Competition Council was set up. The belief that price controls could keep inflationary pressures in check and thus enhance external competitiveness gave way to increased reliance on market forces. But there remain areas in which prices have not yet been liberalised, and the govern- ment still interferes in price-setting for ends other than resource allocation (regional development, for example).

Furthermore, the fact that the Ministry of Finance has sole jurisdiction over mergers and acquisitions may have resulted in non-economic considerations - possibly perceived as protectionist - influencing some decisions. Furthermore, large national mergers, such as that between Air France and UTA, have often been allowed in the interests of industrial policy. Yet most mergers are not scrutinised by the Council; in 1990 the Finance Ministry referred to it only eight cases (out of a total of 639 ). In any case, since the EC regulation on mergers and acquisitions came into force in September 1990, the largest operations are no longer within the purview of the national authorities. Overall, France's competition policy has evolved substantially in recent years and is now more or less comparable to that prevailing in most other EC countries.

The main challenge for French industry now is to adapt its practices to the heightened competition imminent within the single European market, although the keener competitive climate that has been created within the country has already enhanced the capacity of French companies to confront their foreign competitors. France's economic performance in the coming years will depend crucially on the success of its business sector in that enlarged market place.

If public spending is contained, if monetary policy succeeds in preserving the strength of the franc and if inflation is kept in check, competitiveness should improve and interest rates could be brought down, which should in turn bring about a recovery in investment and restore growth to unemployment-reducing rates. But in the longer term the speed of transition to a high-employment economy will be determined by the pace of structural adjustment in both labour and product markets.

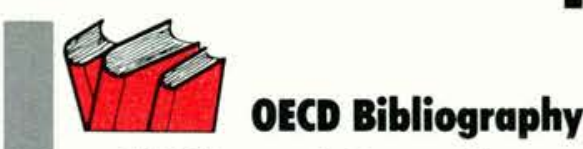

- OECD Economic Surveys: France, 1991

- Stephen Bazen and John P. Martin, 'The Impact of the Minimum Wage on Earnings and Employment in France', OECD Economic Studies, No. 16 , Spring 1991. 


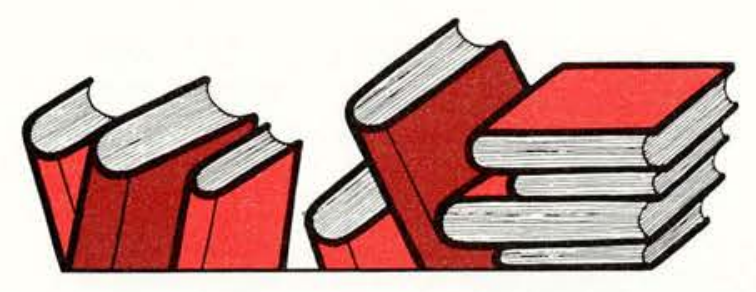

\section{New OECD Publications}

SUE • FILL IN THE FORM WITH THIS ISSUE • FILL IN THE FORM WITH THIS ISSUE • FILL IN THE FORM WITH THIS ISSUE • FILL IN T

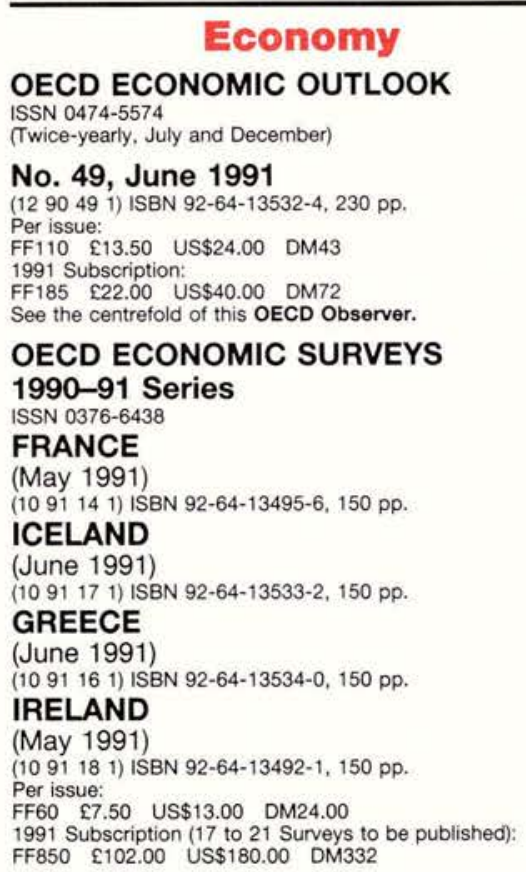

Centre for Co-operation with European Economies in Transition

\section{STATISTICS}

\section{FOR A MARKET ECONOMY}

(May 1991)

The transition from a command economy to a market system implies far-reaching changes in the organisation and conduct of official statistics. These changes affect not only the types of data collected and the ways in which they are presented but also the relationship between the statistical agency and the general public.

This volume is the first in a series of publications by the OECD Centre for Co-operation with European Economies in Transition designed to add to understanding the problems faced by central and eastern European countries as they move from a centrally planned to a marketoriented economy.

It highlights the main conclusions of an OECD conference designed to identify priorities in upgrading statistical systems of countries in transition to meet the needs of a market economy. Among topics covered are the data requirements for policy purposes (including the statistical requirements of the business sector) and for short-term economic forecasting, macroeconomic statistics and the system of national accounts. Strategies for developing new and better statistics are considered with examples from the Soviet Union (including for agriculture), Poland and Romania and, for comparison, selected types of statistics prepared by the OECD.

(14 9104 1) ISBN 92-64-13486-7, 200 pp.

FF150 £20.00 US $\$ 36.00 \quad$ DM58

See Derek Blades, 'The Statistical Revolution', The OECD Observer. No. 170, June/July 1991.

\section{TRANSFORMATION}

OF PLANNED ECONOMIES:

\section{PROPERTY RIGHTS REFORM}

AND MACRO-ECONOMIC STABILITY

Hans Blommestein and

\section{Michael Marrese}

(June 1991)

The transition from central planning to marketbased economies will be critical to the success or failure of the political and economic reforms now underway in central and eastern Europe. Yet by its nature and scale, this transition is without precedent. This report, emanating from two recent seminars, deals with some of the major issues facing those responsible for economic reform: privatisation, property rights, competition and market-oriented 'rules of the game', financial market reform and structural conditions required to attain macro-economic policy objectives.

This report, one of a series, is intended to add to a broader understanding of the problems facing central and eastern European economies in transition. The series is based on collaborative activities between OECD countries and the countries of central and eastern Europe. (14 9103 1) ISBN 92-64-13491-3, $136 \mathrm{pp}$. FF125 \&16.00 US\$30.00 DM48

\section{Development and Aid} FINANCING AND EXTERNAL DEBT OF DEVELOPING COUNTRIES: 1990 SURVEY

(July 1991)

This annual Survey presents the latest information on financial resource flows to developing countries and their external indebtedness. To facilitate interpretation the Survey also provides definitions of terms and concepts used. It places emerging trends within the context of the evolving world economy. Statistical presentations include tables of aggregate resource flows and debt by main income group and continent up to 1990 , as well as detailed data on the total debt and debt servicing of each developing country over the period $1982-89$.

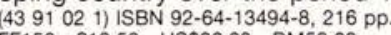
FF150 ₹19.50 US $\$ 36.00$ DM58.00

Development Centre Studies FOREIGN DIRECT INVESTMENT AND INDUSTRIALISATION IN MALAYSIA, SINGAPORE, TAIWAN AND THAILAND

L. Y. C. Lim and Pang Eng Fong (July 1991)

New and powerful forces are changing the shape and character of the world economy. This study examines the causes, consequences and policy implications of emerging foreign investment patterns in Malaysia, Singapore, Taiwan and Thailand, four dynamic Asian economies that are at the forefront of this change.

This study analyses the role of domestic and international forces, differential access to resources and competitive strengths, exchange rate re-alignments and other economic and political factors in determining the allocation and impact of foreign investment. It also analyses the role of foreign investment in the restructuring of the four economies, with particular attention to their electronics and automobile industries.

The distinctive contribution of this study is the way it combines country, industry and company data to analyse the increasingly complex twoway flows of capital, technology and market access between developed countries and the dynamic Asian economies (DAEs).

$(419109$ 1) ISBN 92-64-13498-0, 204 pp.

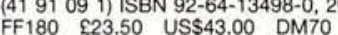

THIRD WORLD DEBT

AND FINANCIAL INNOVATION: THE EXPERIENCES OF CHILE

\section{AND MEXICO}

Hossein Askari

(June 1991)

The financing of economic development received its biggest set-back with the onset of the Mexican crisis of 1982. Hossein Askari proposes solutions for alleviating the debt crisis. He offers practical policies for debtors, creditors and creditor countries to resolve this problem which has slowed growth in many debtor countries. To put all of this in perspective, he provides a critical assessment of the economic and debt management policies of two prominent debtors, Chile and Mexico.

$(419107$ 1) ISBN 92-64-13496-4, 148 pp.

FF130 $₹ 17.00$ US $\$ 31.00$ DM51 
'10 BESTSELLERS'

To order, please use the form inserted in this issue.

1. OECD ECONOMIC SURVEYS 1990-91 SERIES

Austria

(April 1991)

(10 91 11 1) ISBN 92-64-13485-9

FF60 $£ 7.50$ US $\$ 13.00$ DM24

AND ASIAN ECONOMIC DEVELOPMENT Derek Healey

(May 1991)

Japan, already the world's largest donor of aid, is also uniquely positioned to help meet the investment requirements of a capital-hungry world. Challenging conventional wisdom regarding global financial imbalances, the author argues that Japan's balance of payments surplus is not unduly large relative to its level of economic development, and that it is ill-advised to try to reduce this surplus, an important source of investment for development. Focusing on the Pacific-Asian region, this report looks closely at the links between trade, investment and aid, and draws lessons regarding the criteria that will likely affect Japanese overseas investment decisions in the years to come.

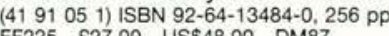
FF225 $₹ 27.00$ US $\$ 48.00$ DM87

\section{Education}

\section{HIGHER EDUCATION MANAGEMENT}

ISSN 1013-851X

Vol. 3, No. 2 (July 1991)

- Funding University Research: the role of overheads in the USA and in EC countries

- Multinational Research Projects: cost calculation and cost management

- EC Research Programmes: how to lobby in Brussels

- Research and European Integration: the impact of Community programmes

- Collaborative Research: twelve institutions in five countries work together on an EC-funded project

- European Integration and University Research: report of a workshop

- Planned Change: using incentives in evaluation

- Making an Impact on Policy: the role of the Hernes Commission in Norway

- Evaluation for Academic Renewal: its impacts on national policies, institutional management and the quality of teaching

- Evaluation of Higher Education: social and political scenarios

- Higher Education Problems: the reflections of George Papadopoulos in his farewell address (89 9102 1) ISBN 92-64-13531-6, 130 pp.

Per issue:

FF90 \&11.00 US\$19.00 DM35

1991 Subscription (3 copies a year)

1991 Subscription (3 copies a year):

\section{REVIEWS OF NATIONAL POLICIES \\ FOR EDUCATION: IRELAND}

(June 1991)

The education system in Ireland, which compares favourably with that of other industrialised countries, has been under pressure throughout the past thirty years, having had to expand post-school education and training provision at considerable speed, cope with a substantial demand for university places, create a non-university sector catering specifically for the demands of an economy in the throes of modernisation, and allocate large amounts for capital investment despite commanding fewer resources than most other OECD countries.

This second OECD review of Ireland's educational policies reveals the significant progress
2. OECD ECONOMIC SURVEYS 1990-91 SERIES

Turkey

(March 1991)

(10 9127 1) ISBN 92-64-13470-0

FF60 $\quad$ 77.50 US $\$ 13.00$ DM24

3. Development Centre Seminars RESTORING FINANCIAL FLOWS TO LATIN AMERICA

(March 1991)

(41 9106 1) ISBN 92-64-13476-X

FF130 $\$ 17.00$ US\$31.00 DM50

4. THE STATE

\section{OF THE ENVIRONMENT}

(January 1991)

(97 9101 1) ISBN 92-64-13442-5

FF180 £22.00 US\$38.00 DM70

5. MACROTHESAURUS

FOR INFORMATION PROCESSING

IN THE FIELD OF ECONOMIC

AND SOCIAL DEVELOPMENT

(February 1991)

(03 9101 1) ISBN 92-64-13450-6

FF210 $£ 25.00$ US\$40.00 DM82

6. THE ECONOMY OF THE USSR Summary and Recommendations by the International Monetary

Fund, the World Bank,

Organisation for Economic Co-operation and Development and the European Bank for Reconstruction and Development (December 1990) (14 9101 1) ISBN 92-64-13453-0 FF80 $\quad 88.00$ US\$15.95 DM25

7. REGIONAL PROBLEMS AND POLICIES IN SWITZERLAND (April 1991)

(70 9102 1) ISBN 92-64-13474-3

FF80 $\quad £ 10.00$ US\$18.00 DM31

8. A STUDY

OF THE SOVIET ECONOMY

Three volumes

by the International Monetary Organisation for Economic

Co-operation and Development, European Bank for

Reconstruction and Development (March 1991)

(14 9102 1) ISBN 92-64-13468-9

FF500 $£ 50.00$ US\$100 DM148

9. SYSTEMIC RISKS IN SECURITIES MARKETS

(February 1991)

(21 9101 1) ISBN 92-64-13454-9

FF100 $£ 12.00$ US\$21.00 DM39

10. EDUCATION

IN OECD COUNTRIES

A Compendium of Statistical

Information 1987-1988

(February 1991)

(91 9006 1) ISBN 92-64-13425-5

FF140 $₹ 17.00$ US $\$ 30.00$ DM55
Fund, The World Bank, that has been achieved since the 1960s and highlights current issues and problems, including the consequences of rapid social and economic change. It underlines several constraints that have weighed on the education system, such as the lack (at least until recently) of a purposeful central authority having the political will, the administrative capacity and the requisite financial resources to formulate and implement reforms, the presence of powerful interest groups outside government which have to be accommodated, and the structural complexity of the system itself.

The major part of this report is devoted to the specific problem of teacher supply and training, and the priority attached to it.

(91 9101 1) ISBN 92-64-13488-3, $156 \mathrm{pp}$.

FF130 \&17.00 US\$31.00 DM50

See John Lowe, 'Ireland and its Teachers', The OECD Observer, No. 169, April/May 1991.

\section{ALTERNATIVES}

TO UNIVERSITIES

(June 1991)

This report charts the recent development of the non-university sector of higher education in certain OECD countries: Austria, Canada, France, Germany, Japan, the Netherlands, New Zealand, Norway, the United Kingdom and the United States. It shows that during the 1980 s this sector most often succeeded in enhancing its standing and recognition among students, employers, and the academic world alike. Its progress in the 1990s will depend on how it meets the challenge of increased competition from the universities on the one side, and the growing postsecondary 'third' sector - market oriented and often private - on the other.

(91 9005 1) ISBN 92-64-13530-8, $112 \mathrm{pp}$

FF90 $\quad$ \&12.00 US $\$ 22.00 \quad$ DM35

See Dorotea Funh, 'Alternatives to Universities', The OECD Observer, No. 161. December 1989/January 1990.

\section{Energy}

International Energy Agency

\section{GUIDELINES}

FOR THE ECONOMIC ANALYSIS

OF RENEWABLE ENERGY TECHNOLOGY

(June 1991)

This report presents guidelines for computing the costs of eight renewable energy technologies: active and passive solar systems, solar thermal and photovoltaic electricity generation, bio-energy, small-scale hydro power, geothermal energy, and wind power. The unique characteristics of each technology have made it difficult to analyse costs and develop comparative economic data. This study outlines a step-by-step approach to assess the feasibility of applying these technologies in the public and private sectors. Case studies illustrate how to use the methodology.

$(619106$ 1) ISBN 92-64-13481-6, $160 \mathrm{pp}$.

FF180 224.00 US\$44.00 DM70

\section{FUEL EFFICIENCY}

OF PASSENGER CARS

(June 1991)

The evolution of passenger-car fuel efficiency has had a strong effect on the rate of transportsector energy consumption in IEA member countries over the last two decades. This book provides a comprehensive overview of the evolution of fuel efficiency of cars. It examines factors affecting fuel demand - such as the development and structure of the fleet - and re- 
views pricing and taxation policies. In addition, it summarises national transport policies, looks at the role of efficiency targets and regulations, and describes ways in which regulatory measures to limit pollution by passenger cars have affected fuel use.

(61 9101 1) ISBN 92-64-13463-8, 80 pp.

FF100 ₹12.00 US\$21.00 DM39

\section{ENERGY IN NON-OECD COUNTRIES}

Selected Topics 1991

(June 1991)

(61 9104 1) ISBN 92-64-13482-4, 80 pp.

FF100 113.00 US\$24.00 DM39

See pp. 25-28 of this OECD Observer.

\section{ENERGY POLICIES - POLAND:} 1991 SURVEY

(May 1991)

This first IEA report on a non-member country outlines the organisation, development and reform of the energy economy of Poland. The IEA conducted its review of Polish energy policies during the winter of 1990-91 in co-operation with the Polish government. The report examines energy supply and demand and discusses the energy outlook and investment requirements. It pays particular attention to energy conservation and protection of the environment. The report offers recommendations on energy policy and identifies areas where the IEA may be of assistance to Poland.

(61 9105 1) ISBN 92-64-113483-2 140 pp.

FF140 \&18.00 US $\$ 34.00$ DM54

See Stephen Perkins, 'Energy Policies for Poland', The OECD Observer. No. 170, June/July 1991.

\section{Nuclear Energy Agency}

DISPOSAL OF RADIOACTIVE WASTE:

REVIEW OF SAFETY

ASSESSMENT METHODS

A Report of the Performance

Assessment Advisory Group

of the Radioactive Waste Management

Committee of the OECD

Nuclear Energy Agency

(June 1991)

The disposal of radioactive waste is a major issue in the nuclear debate. This report provides a concise and accessible overview of the methods available for evaluating the long-term safety of radioactive waste disposal systems, particularly those to be built in deep geological formations.

(66 9103 1) ISBN 92-64-13493-X, 88 pp.

FF95 $\{12.00$ US $\$ 23.00 \quad$ DM37

Disposal of Radioactive Waste Series HETEROGENEITY OF GROUNDWATER FLOW AND SITE EVALUATION Proceedings of the NEA Workshop SEDE-90 Paris, 22-24 October 1990 (June 1991) Bilingual

For underground disposal of radioactive wastes, particular attention must be paid to mobile groundwater, the primary medium by which these wastes could be transported from the repository to man's environment. Thus, in all national programmes for the geological disposal of radioactive wastes, high priority is given to hydrogeological investigation, and in particular to investigation of the spatial variations in groundwater flow systems. These proceedings present the results of a workshop organised to discuss the methods that can be used to obtain the understanding and data required for modelling of such flow systems, as well as the adequacy and appropriateness of the modelling techniques.

669105 3) ISBN 92-64-03346-7, $336 \mathrm{pp}$.

FF200 $\$ 26.00$ US $\$ 48.00$ DM78.00

\section{NUCLEAR LAW BULLETIN}

No. 47

(June 1991), $122 \mathrm{pp}$.

ISSN 0304-341X

Annual Subscription ( 2 issues and supplements):

FF170 £20.00 US\$36.00 DM67

NUCLEAR ENERGY DATA - 1991

(June 1991) Bilingual

Nuclear Energy Data is the OECD Nuclear Energy Agency's annual compilation of basic statistics on electricity generation and nuclear power in OECD countries. The reader will find quick and easy reference to the present status of and projected trends in total electricity generating capacity, nuclear generating capacity, and actual electricity production, as well as on supply and demand for nuclear fuel cycle services.

669108 3) ISBN 92-64-03297-5, $44 \mathrm{pp}$.

FF55 $₹ 7.00$ US $\$ 13.00$ DM2

THE INTERFACE IN NUCLEAR SAFETY

\section{AND PUBLIC HEALTH}

(June 1991)

Radiation protection and nuclear safety represent complementary approaches to the protection of man and his environment from risks associated with ionising radiation. They share a common objective, but pursue their aims in different ways.

Recent years have seen a number of developments in both fields, including the revision by the International Commission on Radiological Protection (ICRP) of its basic radiation protection recommendations, the growing attention to radon in buildings, the work to define quantitative safety objectives, as well as the prevention and management of severe accidents.

A recent international seminar organised by the OECD Nuclear Energy Agency brought together experts from the two communities to discuss these and other issues of common concern. This volume contains the papers presented and an extensive record of the discussions held during the seminar. (66 9107 3) ISBN 92-64-03349-1, 252 pp. FF200 ₹26.00 US\$48.00 DM78

\begin{tabular}{|c|}
\hline Financial Affairs \\
\hline $\begin{array}{l}\text { FINANCIAL MARKET TRENDS } \\
\text { No. 49, June } 1991 \\
\text { ISSN 0378-651X ( } 3 \text { issues per year) } \\
(2791021), 130 \text { pp. } \\
\text { Per issue: } \\
\text { FF8 \&10.00 US } \$ 17.00 \text { DM } 33.00 \\
1991 \text { Subscription: } \\
\text { FF200 \&24.00 US } \$ 42.00 \text { DM78 }\end{array}$ \\
\hline
\end{tabular}

\section{Food and Agriculture MEAT BALANCES IN OECD COUNTRIES: 1983-1989}

(July 1991) Bilingual

Meat Balances in OECD Countries presents international comparisons of production, trade and consumption for each category of meat for 1983-89. It enables the commodity analyst to follow, for each OECD country, the flow of meat by category from production to consumption.

Other OECD agricultural statistical series include Economic Accounts for Agriculture,
Food Consumption Statistics and Milk and Milk Products Balances in OECD Countries. (51 91013 ) ISBN 92-64-03502-8, $152 \mathrm{pp}$

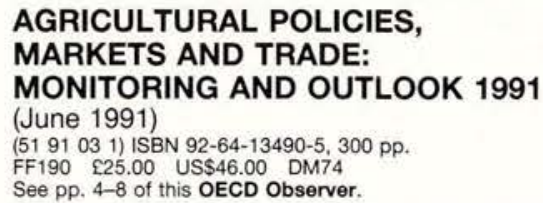

\section{Science and Technology} CHOOSING PRIORITIES IN SCIENCE AND TECHNOLOGY

(June 1991)

In OECD countries a significant share of government expenditure $-4.4 \%$ on average - is devoted to science and technology. How and by whom are the directions of this scientific and technological effort determined? These are the essential questions dealt with in this study.

Deciding on priority areas is a very complex process. Not only do players often have conflicting aims, governments have to make drastic choices in the face of severe financial constraints, and the internal logic of science must be reconciled with the economic requirements of society. This publication describes efforts of OECD countries to make the most rational choices, and underlines some recent developments such as the increasingly active role of regional authorities and the growing influence of international competition and co-operation. (92 9104 1) ISBN 92-64-13499-9, 104 pp.

FF100 $\$ 13.00$ US $\$ 24.00 \quad$ DM39

See Gabriel Drilhon, "Choosing Priorities in Science and Technology', The OECD Observer, No. 170, June/July 1991.

ICCP (Information, Computer and Communications Policies) Series

No. 23 - UNIVERSAL SERVICE

AND RATE RESTRUCTURING

IN TELECOMMUNICATIONS

(June 1991)

This report examines two issues at the centre of the debate concerning the restructuring of telecommunications services. The first study reviews the concept of universal service in European telecommunications and related regulations. The second provides a detailed analysis of the patterns of telecommunication rate restructuring observed in eighteen OECD countries over the past decade.

(939101 1) ISBN 92-64-13497-2, $196 \mathrm{pp}$.

FF2 15.00 £28.00 US\$52.00 DM84

Trade
SERVICES IN CENTRAL
AND EASTERN EUROPEAN
COUNTRIES
(May 1991)
This study demonstrates that the development
of services should be given a prominent place
in the transition process currently underway in
the central and eastern European countries and
should contribute to the expansion of their for-
eign trade. While there has been general recog-
nition that the service sector in these countries
has played an insufficient role in their
economies and foreign trade, the subject has
not so far been analysed in adequate detail.
This report for the OECD Trade Committee thus
aims to fill in these gaps and devotes particular


attention to the service sectors in Poland, Hungary and the Czech and Slovak Federal Republic.

(22 9101 1) ISBN 92-64-13487-5, 54 pp.

FF75 £10.00 US\$18.00 DM30

\begin{tabular}{l} 
Transport \\
ECMT (European Conference \\
of Ministers of Transport) \\
PROSPECTS FOR EAST-WEST \\
EUROPEAN TRANSPORT \\
International Seminar, Paris \\
$6-7$ December 1990 \\
(April 1991) \\
Given the previous political and economic con- \\
text, East/West transport had been deteriorat- \\
ing over a long period. Now, as Europe opens \\
up, the considerable potential for flows of trade \\
and tourism can be seen, although the conse- \\
quences for the transport sector - and the \\
adjustments called for - give rise to many com- \\
plex problems. \\
The ECMT seminar has set out all the various \\
aspects of these problems, together with the \\
broad lines of a pan-European transport policy. \\
Attention is drawn, for example, to the possible \\
saturation of infrastructure at those points \\
where environmental problems are most sensi- \\
tive. It is likewise pointed out that the future \\
organisation of transport markets should pro- \\
vide for an acceptable pattern of competition \\
while at the same time integrating the new \\
sources of supply offered by the central and \\
eastern European countries and making the most \\
of the particular advantages and potential \\
offered by each mode (railways, waterways, \\
roads). It should also be possible to have \\
private - sector participation in the funding of \\
priority infrastructure. This seminar has clearly \\
prepared the way for further analysis and \\
courses of action. \\
(75 910211 ISBN $92-821-1153-9556$ pp. \\
FF350 442.00 E74.00 DM136 \\
\hline
\end{tabular}

\section{Statistics \\ OECD ECONOMIC OUTLOOK HISTORICAL STATISTICS: 1960-89 (May 1991) Bilingual \\ The Economics and Statistics Department (ESD) of the OECD publishes statistics on the main subjects influencing the development of the economy, such as national accounts, for- eign trade, labour force, leading indicators and short-term statistics. Most are available as printed publications, on magnetic tapes, and on diskettes, and, in the case of foreign trade by commodity, on microfiches. In addition, ESD puts forward its own forecasts in its semi-annual publication OECD Economic Outlook, based on a review of each member country. Particular attention is paid to the policies that govern- ments are adopting to solve present economic problems. \\ (12 9101 3) ISBN 92-64-03348-3, 170 pp. \\ FF110 \&14 US $\$ 26.00$ DM42}

\section{QUARTERLY NATIONAL ACCOUNTS}

ISSN 0304-3738 Bilingual

1/1991 (May 1991)

(36 910 13), $176 \mathrm{pp}$

Per issue:

FF90 $£ 11.00$ US\$17.00 DM35

1991 Subscription

$\$ \$ 64.00$ DM117

- Also available on diskette
International Energy Agency

\section{ENERGY STATISTICS}

\section{OF OECD COUNTRIES: $1980-89$}

(June 1991) Bilingua

Contains a compilation of energy supply and consumption data in original units for coal, oil, gas and electricity. Complete supply/consumption data are shown from 1980 to 1989. Data on electricity gross and net production, capacity and trade by origin and destination are also included. Summary tables for all time periods are shown for the category 'other solid fuels' such as wood, waste, etc. as well as for heat. Includes definitions of products and flows and explanatory notes on the individual country data.

(61 9108 3) ISBN 92-64-03299-1, 720 pp.

FF350 \&45.00 US\$84.00 DMi36

\section{ENERGY BALANCES}

OF OECD COUNTRIES: $1980-89$

(July 1991) Bilingual

(61 9107 3)ISBN 92-64-03500-1, 450 pp.

FF250 \&32.00 US\$60.00 DM98

\section{QUARTERLY OIL STATISTICS}

AND ENERGY BALANCES *

Fourth Quarter 1990 (April 1991)

ISSN 0378-6536 Bilingual

(60 91013$), 336 \mathrm{pp}$

Per issue:

FF200 £24.00 US\$42.00 DM8

Annual Subscripion:

FF750 $£ 90.00$ US $\$ 158.00$ DM293

- Also available on diskette

\section{BASIC SCIENCE}

\section{AND TECHNOLOGY STATISTICS}

(July 1991) Bilingual

This new bilingual publication, to appear every two years, contains data on scientific and technological activities in the 24 OECD countries and provides recent basic statistics which are not available from any other source in an internationally comparable presentation. The information is presented in sets of 22 tables for each country which give inter alia detailed data on: - gross domestic expenditure on R\&D by sector of performance, by type of costs and by source of funds

- business enterprise intramural expenditure on R\&D for 39 industries, by type of costs and by source of funds

- current domestic expenditure by sector of performance and by type of activities

- higher education intramural expenditure on R\&D by field of science and by type of costs

- R\&D personnel by sector of employment, by function, by level of qualification and by main scientific field

- statistics on patents: number of patent applications (national, domestic, foreign, external)

- the technology balance of payments by type of transfer

These are the base series for Main Science and Technology Indicators (68pp.), a twiceyearly statistical publication which gives a general overview of recent trends in the structure and results of S\&T activities. Basic Science and Technology Statistics also includes most of the data used to prepare the detailed analytical reports OECD Science and Technology Indicators which are issued at two-year intervals.

With 451 tables.

(92 9102 3) ISBN 92-64-03501-X, $372 \mathrm{pp}$

FF250 $₹ 32.00$ US $\$ 60.00$ DM98

- Also available on diskette

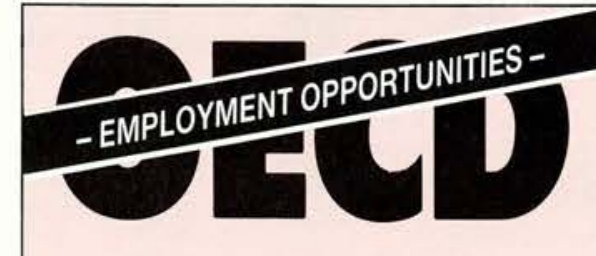

OECD HEADQUARTERS, PARIS

Vacancies occur in the OECD Secretariat in the following areas:

Public Administration

Balance of Payments

National Accounts

Agricultural Economics

Development Economics

Energy Economics

Industrial Economics

Labour Economics

Monetary Economics

Econometrics

Environment

Urban Studies

Fiscal Policy

Nuclear Engineering

Macro-economics

Nuclear Physics

Education Policies

Social Affairs

Statistics

Computing and Communications

\section{- Qualifications:}

relevant university degree; at least two or three years' professional experience; very good knowledge of one of the two official languages of the Organisation (English and French) and ability to draft well in that language; good knowledge of the other.

\section{- Initial appointment:}

two or three years.

\section{- Basic annual salary:}

from FF 252,000 to FF 329,000 (Administrator) and from FF 363,00 (Principal Administrator), supplemented by allowances depending on residence and family situation. Vacancies are open to both male and female candidates from OECD member countries. Applications, in English or French (specifying area of specialisation and enclosing detailed curriculum vitæ), should be marked 'OBS and sent to:

Human Resource Management OECD

2 , rue André-Pascal

75775 PARIS CEDEX 16 FRANCE
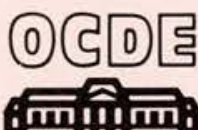
iाtiाiti

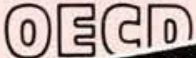

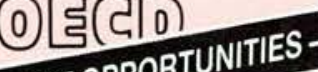




\section{Where to obłain OECD Publications}

ARGENTINA

CARLOS HIRSCH S.R.L.

Galería Gũemes, Florida $165,4^{\circ}$ Piso

1333 Buenos Aires Tel. 30.7122, 331.1787 y 331.2391

Telegram: Hirsch-Baires

REF:S/2901

Telex: 21112 UAPE-AR.

AUSTRALIA

D.A. Book (Aust.) Pty. Ltd

P.O.B. 163

Mitcham, Victoria 3132

Tel. (03) 873.441

AUSTRIA

OECD Publications and Information Centre

Schedestrasse

D-W 5300 Bonn 1 (Germany) Tel. (49.228)21.60.45

Telefax: (49.228)26.11.04

Gerold \& Co.

Graben 3

Tel. 102221533.50 .14

Wien I

Tel. (0222)533.50.14

BELGIUM

Jean De Lannoy

Avenue du Roi 202

B-1060 Bruxelles

Telex: 63220

Tel. (02)538.51.69/538.08.4 Telefax: (02)538.08.4

\section{CANADA}

Renouf Publishing Company Ltd.

1294 Algoma Road

Ottawa, ON. K1B 3W8

Telex: 053-4783

Stores:

61 Sparks Street

Ottawa, ON. K1P 5R1

211 Yonge Street

Toronto, ON. M5B 1M4

Federal Publications Inc.

165 University Avenue

Toronto, ON M5H $3 B 8$

Telefax: (416)581.1743

1185 rue de I'Université

1185 rue de I'Université

Les Editions La Liberté Inc.

3020 Chemin Sainte-Foy

Sainte-Foy, PO G1X 3V6

Telefax: (418)658.3763

Tel. $(613) 741.4333$
Telefax: $(613) 741.5439$

Tel. (613)238.8985

Tel. (416)363.317

Tel. (416)581.1552

Tel. (514)954-1633

Tel. (418)658.3763

DENMARK

Munksgard Export and Subscription Service

35. Nørre Søgade, P.O. Box 2148

Tel. $(45$ 33) 12.85 .70 Telex: 19431 MUNKS DK Telefax: (45 33) 12.93 .87

FINLAND

Akateeminen Kirjakaupp

Keskuskatu 1, P.O. Box 128

00100 Helsiniki

Telex: 125080

Tel. (358.0)1214 Telefax: (358.0)121.444

GREECE

Librairie Kauffmann

28, rue du Stade

Telex: 218187 LIKA Gr

Tel. 322.21.60

HONG KONG

Swindon Book Co. Ltd.

13 - 15 Lock Road

Kowloon, Hong Kong
Telex: 50441 SWIN HX

ICELAND

Mál Mog Menning

Laugavegi 18

INDIA

Oxford Book and Stationery Co.

Scindia House

New Delhi 11000

Telex: 3161990 AM IN

17 Park Street

70001

INDONESIA

Pdii-Lip

P.O. Box 269/JKSMG/88

Jakarta 12790

Telex: 62875

\section{IRELAND}

TDC Publishers - Library Suppliers

12 North Frederick Street

Dublin 1

Telex: 33530 TDCP EI

Tel. 366.80 .31 Telefax: 739.49 .75

Tel. $15199 / 24240$

Directeur: Lucien Dantin

Tel. 331.5896/5308

Tel. 240832

Tel. 744835/749677

Telefax: 748416

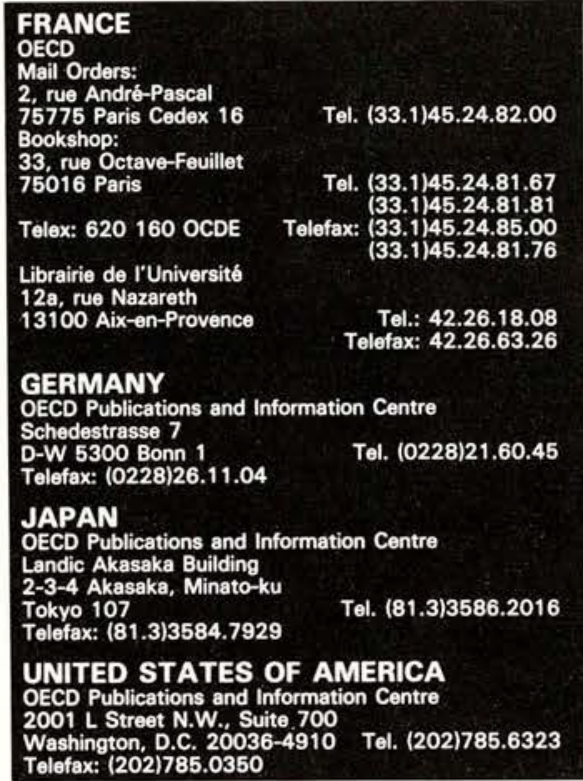

\section{ITALY}

Libreria Commissionaria Sanson

Via Benedetto Fortini, 120/10

Casella Post. 552

To125 Firenze

Telex: 570466

Via Bartolini 29

Tel. 36.50 .83

a diffusione delle pubblicazioni OCSE viene assicurata

dalle principali librerie ed anche da:

ditrice e Libreria Herder

Plazza Montecitorio 120

Telex: NATEL | 621427

Tel. 679.46 .28

Libreria Hopli

Via Hoopli 5

20121 Milano

elex: 31.33 .95

Libreria Scientifica

Via Meravigli 16
20123 Milano

Telefax: 800175

Tel. 86.54 .46

Tel. 86.54.46
Telefax: $(02) 805.28 .86$

KOREA

Kyobo Book Centre Co, Ltd.

Kyobo Book Centre Co. Ltd.
P.O. Box 1658, Kwang Hwa Moon

P.O. Box 1658, Kwang Hwa Moon Tel. (REP)730.78.91
Seoul

Telefax: 735.0030

MALAYSIA/SINGAPORE

Co-operative Bookshop Ltd.

Co-operative Booksh

P.O. Box 1127, Jalan Pantai Bar

59700 Kuala Lumpur

Malaysia

Tel. $756.5000 / 756.5425$

Telefax: 757.3661

Information Publications Pte. Ltd

Pei-Fu Industrial Building

24 New Industrial Road No. 02-06

Singapore 1953

Tel. $283.1786 / 283.1798$

Telefax: 284.8875

NETHERLANDS

SDU Uitgeverij

Christoffel Plantijnstraat 2

Postbus 20014

2500 EA's-Gravenhage

Voor bestellingen:

Tel. (070 3)78.99.11

Tel. (070 3)78.98.80

486 stdru

Telefax: (070 3)47.63.5

NEW ZEALAND

Customer Senict

33 The Esplanade - P.O. Box 38-900

Petone - Wellington

Tel. (04)685-555

NORWAY

Narvesen Info Center - NIC

Bertrand Narvesens vei 2

P.O. Box 6125 Ettersta

0602 Oslo 6

Telex: 79668 NIC N

1. (02)57.33.00

PAKISTAN

Mirza Book Agency

65 Shahrah Quaid-E-Azam

Lahore 3

PORTUGAL

Livraria Portugal

Rua do Carmo 70-74, Apart. 268

1117 Lisboa Codex

Telefax: (01) 347.02.64

Tel.: $347.49 .82 / 3 / 4 / 5$

SINGAPORE/MALAYSIA

See "Malaysia/Singapore"

SPAIN

Mundi-Prensa Libros S.A.

Castello 37, Apartado 1223

Telex: $49370 \mathrm{MPL}$

Tel, 431.33 .99

Libreria Internacional AEDOS

Consejo de Ciento, 391

08009 - Barcelona

Telefax: (93) 317.01.41

SRI LANKA

Centre for Policy Research

c/o Mercantile Credit Ltd.

55. Janadhipathi Mawatha

Telex: 21138 VAVALEX CE

Tel. 438471-9, 440346

SWEDEN

Fritzes Fackboksföretaget

Box 16356

Regeringsgatan 12

Telex: 12387

Telex: 12387

Subscription Agency:

Nordenflychtsvăgen 74, Box 30004

10425 Stockholm

Tel. (93) 301.86.15

Telex: 19937

(0). 13.67 .00

SWITZERLAND

OECD Publications and Information Centre

Schedestrasse 7

D-W 5300 Bonn 1 (Germany) Tel. (49.228)21.60.45

Telefax: (49.228)26.11.04

Librairie Payot

6 rue Grenus

1211 Genève 1

Telex: 28356

Tel. (022)731.89.50

Subscription Agency: Naville S.A.

7. rue Levrier

Telefax: (022) 738.48.03

Tél.: (022) 732.24.00

Maditec S.A.

Chemin des Palettes 4

To20 Renens/Lausanne

Tel. (08)23.89.00

Tel. $(08) 20.50 .21$

United Nations Bookshop/Palais des Nations

1211 Genève $10 \quad$ Tel. (022)734.14.73 Telex: 412962

Telefax: (022)740.09.3

TAIWAN

Good Faith Worldwide Int'l. Co. Ltd.

9 th Floor, No. 118, Sec. 2

Chung Hsiao E. Road

Telefax: (02) 394.9176

Tel. $391.7396 / 391.7397$

THAILAND

Suksit Siam Co, Ltd

1715 Rama IV Road, Samyan

Bangkok 5

Tel. 251.1630

TURKEY

Kültur Yayinlari Is-Tũrk Ltd. Sti.

Atatūrk Bulvari No. 191/Kat. 21

Dolmabahce Cad. No. 29

Besiktas/Istanbul

Telex: $43482 B$

UNITED KINGDOM

HMSO

Gen. enquiries:

P.O. Box 276, London SW8 5DT

Personal Callers HMSO Bookshop

49 High Holborn, London WC1V $6 \mathrm{HB}$

Telex: 297138 Telefax: 0718732000

Branches at: Belfast, Birmingham, Bristol, Edinburgh,

Manchester

VENEZUELA

Libreria del Este 52 Aptdo, 60337 Edificio Galipán

Caracas 106 Tel. 951.1705/951.2307/951.1297

Telegram: Libreste Caracas

YUGOSLAVIA

Jugoslovenska Knjiga

Knez Mihajlova 2, P.O. Box 36

Beograd

Tel.: (011)621.992

Telefax: $(011) 625.970$

Orders and inquiries from countries where Distributors have 


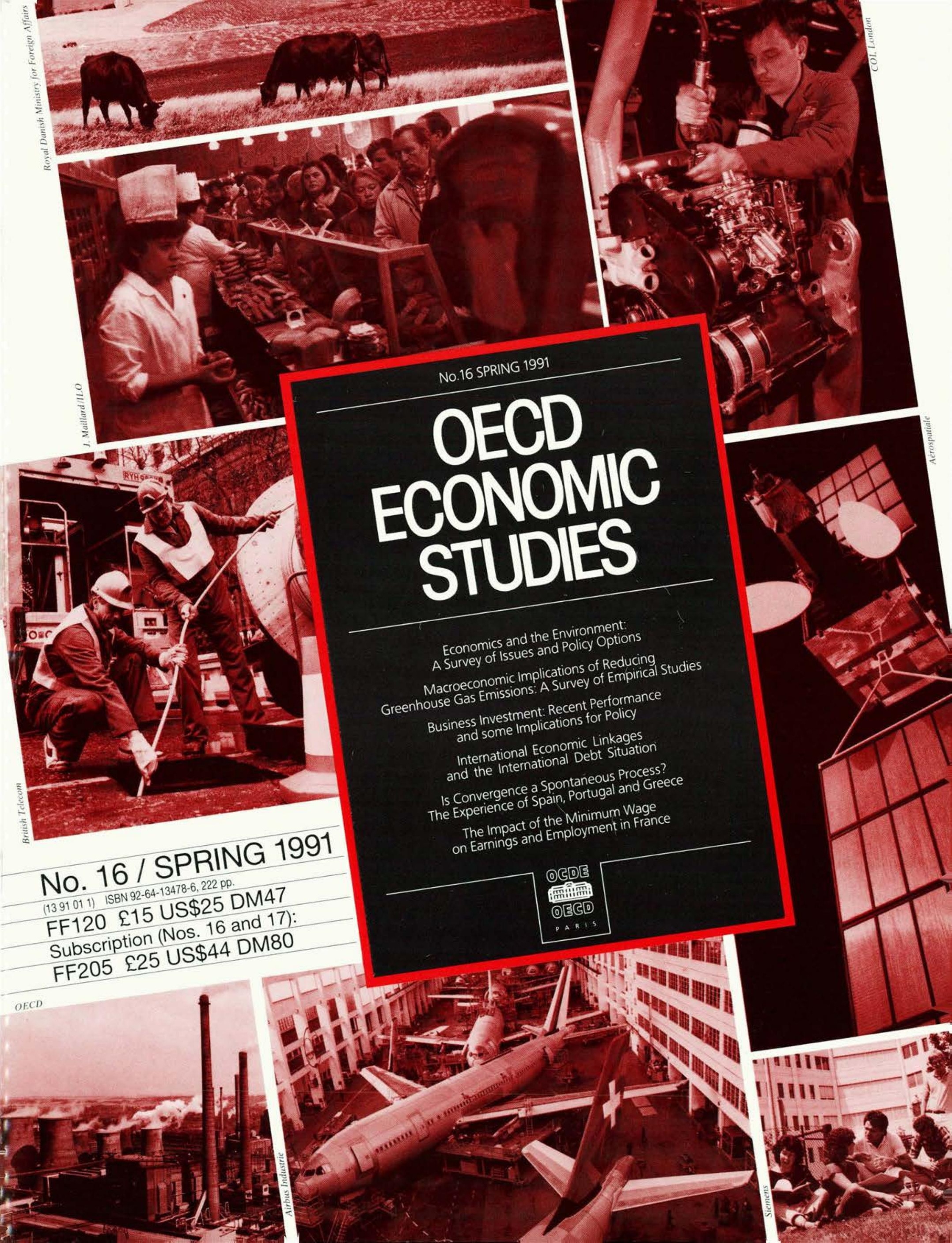




\section{OECD Publications}

the

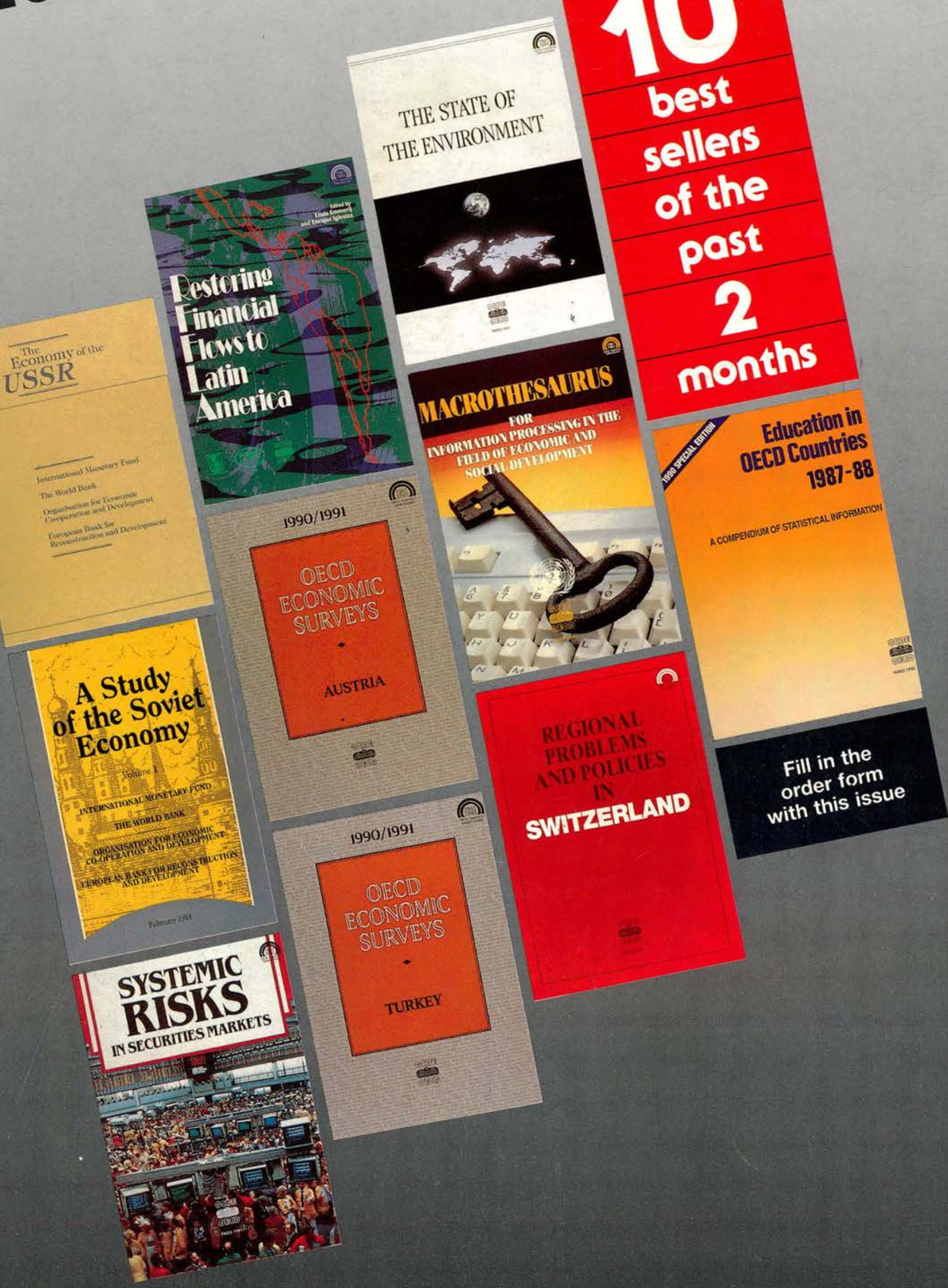


The Council of the OECD met on 4 and 5 June 1991 at Ministerial level. The meeting was chaired by Mr Wim Kok, Deputy Prime Minister and Minister of Finance, and Mr Koos Andriessen, Minister of Economic Affairs, the Netherlands. The ViceChairmen were the Rt Hon Douglas Hurd, MP, Secretary of State for Foreign and Commonwealth Affairs, the Rt Hon Norman Lamont, MP, Chancellor of the Exchequer, and the Rt Hon Peter Lilley, MP, Secretary of State for Trade and Industry, United Kingdom.

A t a time of major international political change, Ministers re-affirm OECD member countries' long-standing directions and basic objectives of economic and social policy. They have accordingly identified a number of policy challenges, on which resolute action will be taken:

- The basic values shared by the OECD countries - pluralistic democracy, respect for human rights, and market-oriented economies - are finding increasing recognition throughout the world. The peoples of many countries outside the OECD can progressively benefit from this change in their political, social and economic life. Ministers express their countries' determination to increase economic relations with nonmember countries pursuing these basic values. In this regard, ministers welcome the launching of the Partners in Transition Programme, with the CSFR, Hungary and Poland.

- In an increasingly interdependent world, a particular responsibility rests with OECD countries to create and sustain a favourable global economic environment. This is all the more necessary as there are widespread concerns about high levels of unemployment in many
OECD countries. Ministers stress that, after the recent slow-down, they aim to return to sustained expansion with price stability. Firmly rooted in an ever closer co-ordination, economic policies will continue complementary macroeconomic and structural measures. Macroeconomic policies should support economic recovery and sustain growth while promoting price stability. Active structural policies are crucial because they expand supply potential and increase flexibility, thereby permitting stronger sustainable growth and higher employment levels. Such growth with price stability in OECD countries is important to the world at large, not only because it stimulates economic activity everywhere, but also because it allows for increased savings to be mobilised for investment, which in turn assures future economic growth.

- A free and open system of trade, investment and capital flows is vital. Early agreement on a substantial and comprehensive outcome to the Uruguay Round trade negotiation is the highest priority for both structural reform and international economic co-operation. In the face of increasing globalisation of economic activity, it will be a major step towards defining and putting into place new rules and disciplines required for the world economy to function well, to the benefit of all. In this respect, Ministers re-affirm their resolve to fight protectionism in all its forms.

- Technological progress, which is both a cause and an effect of strengthened competition and globalisation, contributes importantly to economic growth. The adaptation to changing technology entails a continuing process of adjustment throughout the economy as well as in society at large. While the central role in this process falls to firms and to individuals, governments bear an important responsibility, including in achieving policy coherence and convergence so as to facilitate adaptation to new technologies within countries and to prevent potential international frictions.

- It is essential that all - be they countries or individuals - should benefit from economic growth. Ministers stress the need for OECD and non-member countries alike to formulate coherent policies in the fields of economics, environment, social affairs and technology that are mutually reinforcing in support of broadly

\section{OECD Enters Into Partnership Agreements with CSFR, Hungary and Poland}

On 4 June 1991 the Deputy Prime Ministers and Ministers of the Czech and Slovak Federal Republic, Hungary and Poland signed memoranda of understanding with the Chairman of the OECD Council at Ministerial level, Wim Kok, and the OECD Secretary-General, JeanClaude Paye, in the presence of ministers of foreign and economic affairs from the $24 \mathrm{OECD}$ member countries. The memoranda concern the 'Partners in Transition' (PIT) programmes, which set the framework for wide economic co-operation between the OECD and the three central European countries.

The signatories from the three central European countries were the Deputy Prime Minister and Minister of Finance of the Republic of Poland, Leszek Balcerowicz, the First Deputy Prime Minister and Minister of Foreign Affairs of the CSFR, Mr. Jirí Dienstbier, and the Minister of International Economic Relations of the Republic of Hungary, Béla Kádár.

The PIT programmes have been established as an addition to activities already in hand with central and eastern European countries under the management of the OECD Centre for Co-operation with European Economies in Transition (CCEET). They are specifically designed for countries that have particularly demonstrated their commitment to a rapid transition to a market economy and to pluralistic democracy, and have expressed the wish to establish special links with the OECD. The selection of activities to be carried out under each PIT programme responds to the specific requirements of each partner in its transition toward a market economy and helps the countries prepare to meet the conditions for membership of the OECD.

The content of the programmes will be defined and set up jointly by the CCEET and the authorities of the partner countries, and reviewed on an annual basis through three special liaison committees composed of representatives of OECD member countries, the PIT countries, the Centre and the OECD secretariat. Among the activities to be undertaken, the OECD will carry out country reviews of the economies of the PIT countries, aimed at providing their authorities with a general orientation on reforms or other policy measures affecting macroeconomic, sectoral and structural aspects. Various forms of technical assistance in the implementation of policies are featured in each programme.

In particular, delegates from the three PIT countries will participate in selected meetings of OECD committees and working groups. The OECD will provide certain training for officials from the three countries and will give PIT countries access to its on-line information and data banks. 
based sustainable development. Ministers reaffirm their strong commitment to enhanced co-operation with developing countries.

Ministers consider that, because of the range and interlocking nature of its activities, the OECD has the capacity to make a particularly useful contribution in response to those challenges.

\section{The Economic Situation}

OECD economic growth has slowed significantly over the past year, with output actually falling in some countries, and unemployment is again increasing. Some slowing of demand was necessary in countries exposed to overheating and to reduce current-account deficits where they posed problems. The slowing of demand and tight monetary policy contributed to a reduction of underlying inflationary pressures. The weakening of demand was temporarily intensified by the sharp increase in oil prices and the marked fall in confidence occasioned by the Gulf crisis and war. In some countries and economic sectors, the negative effects may prove to be more protracted.

While the risks of continuing weak activity, due in part to the persistence of high real interest rates and to the slowdown in investment in many countries, cannot be ignored, OECD activity is projected to recover in coming months, underpinned by a number of factors: - the reduction of uncertainty following the end of the Gulf war which has led to a rebuilding of confidence in some countries

- the reversion of oil prices to levels which obtained before the Gulf crisis

- notable falls in interest rates in some countries

- the substantial reduction of major external imbalances, removing a threat to the outlook - continued growth in Japan and Germany (where the demand effects from unification remain strong).

\section{Macro-economic Policy Directions}

The basic medium-term requirements for macro-economic policy remain unchanged. It is important that sound monetary and fiscal policies should lay the groundwork for a reduction in real interest rates and a sustained global economic recovery with price stability. This will help reduce overall unemployment in OECD countries. Monetary policy will therefore continue to be conducted with vigilance and prudence, particularly in countries where inflation remains a concern. In many countries, progress in reducing inflation has provided scope for lowering interest rates.

The persistence of high real interest rates and the aggregate deficit of the OECD current account suggest that the level of savings is insufficient to meet demands for investment. In the light also of the investment needs of developing countries and countries in central and eastern Europe, it is all the more essential that OECD countries reduce their overall absorption of saving, while at the same time reducing excessive current-account imbalances between themselves.

Fiscal policy is also important in this context and will continue to be set within a mediumterm framework for budget objectives. Measures to reduce persistent budget deficits and/or correct distortions in tax and regulatory systems (including in relation to private savings can increase the overall level of saving and investment and produce a better allocation of resources. Pressures likely to arise in some areas of public spending will be attenuated by improving management and allocative efficiency of the public sector, in part by raising productivity in certain public services and by identifying those expenditure items which can most effectively and equitably be subjected to competition.

Ministers welcome measures announced by the United States and other budget-deficit countries to reduce their budget imbalances in accordance with medium-term plans and recognise that efforts may be needed also in othe countries to strengthen public-sector savings. They note the special nature of the present budget deficit in Germany in the context of German unification and the decisions already taken by the German government to reduce it over the medium-term. Ministers stress the importance of implementing fully these budgetdeficit reduction plans.

The recovery of growth will create employment, but sustainable reductions in unemployment over the medium term will also require appropriate structural policies, including in respect of removing rigidities in the labour market and improving education and training.

It is essential that economic policy be credible, that policies and objectives be stated clearly, and that their international compatibility be ensured. Further strengthening of international economic co-operation remains a top priority. Close policy co-operation will help to provide a sound global economic environment. Through its widespread activities and broad geographic coverage the OECD can play a useful role in this regard. Continued co-operation in respect of exchange rates will contribute to greater exchange market stability and thereby to a better functioning of the international monetary system.

\section{Structural Priorities in a Global Context}

In the present environment of increasing globalisation and fast-paced technologica advance, the critical importance of a flexible and resilient economy is highlighted as never before. The full benefits of expanding international trade can be achieved only by economies that are fully adaptable. Ministers underline therefore the major role that structural policies have to play in improving productive potential so that economies can grow faster and more sustainably, with high employment and price stability, leading to increased wellbeing of the people. These policies cover, in a closely interrelated manner, the full span of economic and social domains. In each of these, they encompass domestically defined and implemented measures as well as international co-operation in its varied modalities, including legally binding agreed instruments.

Ministers consider that, in addition to its role in macro-economic co-operation, the OECD is particularly well placed to help clarify structural problems and relevant solutions, in particular because of the variety of its competences and because its Secretariat and committee system can manage issues which cross traditionally compartmentalised policy domains. Ministers also stress the important role already played by the OECD's structural surveillance programme. It provides the forum for multilateral peer review, which fosters the process of structural reform and encourages operational approaches to it. In this connection, Ministers welcome the proposals of the Economic Policy Committee for making structural surveillance more effective. Ministers call upon the Organisation further to develop and deepen its work on structural issues and, where appropriate, to:

- explore their policy interconnections

- assess the most effective ways of taking them into account in the process of policy formulation

- in those areas which lie beyond the ambit of current international negotiations, consider the feasibility of elaborating operational arrangements.

Ministers highlight, in the paragraphs which follow, these broadly interrelated areas they assign to the Organisation for structural work: economic (trade, agriculture, rural development, technology, competition, financial matters); social (labour-market policies and human resource development, social policy, migration, urban affairs); environment; public sector management; and energy.

\section{The Economic Field}

Trade

The Uruguay Round has the highest priority on the international economic agenda. Success here, which will further strengthen the open multilateral trading system, remains crucial to continued growth of world trade and the world economy and would greatly enhance the process of structural reform. Ministers therefore agreed that the Round must be brought to a substantial and comprehensive conclusion as early as possible, preferably before the end of the year. They recognise that to achieve this goal, political decisions to overcome major existing differences are needed by all participants without delay, the pace of negotiations must be intensified in all areas, and substantial progress must be achieved by the end of the summer. Ministers took note of the report of the Trade Committee, and endorsed its conclusions. They are determined to build on earlier progress to achieve a wide-ranging, substantial, balanced and global agreement and a complementary institutional strengthening of the GATT system. They are committed to their standstill obligations, and not to undermine the prospects of success by trade action contrary to GATT rules, to the Round's objectives or the headway made so far. 
In this respect, Ministers strongly re-affirm their rejection of tendencies toward managed trade, unilateralism, bilateralism and sectoralism. Bilateral trade disputes should be resolved in ways consistent with GATT rules and procedures. They underline that the negotiations should not be a pretext for delaying autonomous efforts towards structural adjustment in the trade area. The improved market access and strengthened trading system resulting from the successful conclusion of the Uruguay Round will foster further integration of an ever-growing number of countries into the trade and world economic system.

Regional integration is another significant area of development in trade relations. It can stimulate the multilateral liberalisation process and should be in conformity with international obligations and with the objective of maintaining and strengthening the multilateral trading system. Ministers invite the Organisation to continue to monitor developments in the field of regional integration.

Looking beyond the Uruguay Round to the trade issues of the 1990s, ministers emphasise the need to address the new dimensions of trade policy. This includes a whole range of issues which arise because of the increasing globalisation of the world economy and the closer relationship between trade policy and competition, investment, technology and innovation, and environment policies. The increasingly international scope of economic activity has seen the emergence of areas in which the needs of private agents and governments run ahead of the existing 'rules of the game'. There is a perceived need for better understanding of these issues and, where appropriate, convergence of policy approaches and consideration of fresh rules. Many issues, traditionally viewed largely from a domestic policy perspective, have taken on an international dimension, affecting the setting of trade and investment policies themselves. Hence, widening the consideration of trade policies in the 1990s to take account of new developments will go hand-inhand with efforts to avoid conflict with other policy spheres.

\section{Agriculture}

Agricultural Reform. Ministers acknowledge that there has been very limited progress in agricultural reform along the lines they set out when they met in 1987 and in 1988, particularly in relation to the progressive market orientation of agricultural production and trade. They take note of the 1991 Monitoring and Outlook Report by the Agriculture and Trade Committees and endorse its conclusions. ${ }^{1}$ Support to agriculture, as measured by producer subsidy equivalents (PSEs), increased in 1990 after declining in 1988 and 1989 . The OECD Secretariat has estimated transfers from taxpayers and consumers at nearly $\$ 300$ billion for 1990 , slightly above the previous peak of 1987 when expressed in dollar terms. Structural surpluses have re-emerged in the OECD area for most commodities, confirming that the temporarily more balanced market situation of 1988 and 1989 was due mainly to drought or to the impact of supply-control efforts. World prices dropped in 1990 compared with the previous year; there has been an upsurge in export assistance; and trade tensions have remained unabated. Unless policies are improved, the budgetary and economic costs, as well as trade tensions, are likely to rise and the economic prospects of countries dependent on agricultural exports are likely to be seriously affected, including developing countries.

Following on all the reform principles defined in 1987 and 1988, Ministers confirm their commitment to achieving substantial progressive reductions of agricultural support and protection, in particular in the context of the Uruguay Round, through the framework approach set forth in the Mid-Term Review. To this end, the participants have agreed to conduct negotiations to achieve specific binding commitments on each of the following areas: domestic support, market access, and export competition; and to reach agreement on sanitary and phytosanitary issues. Account will be taken of participants' non-trade concerns. In order to facilitate adjustment, specific measures, such as certain forms of direct income support payments or autonomous quantitative restrictions of supply can be envisaged. Such measures, however, must not introduce new economic distortions to international markets. Agricultural reform, to the extent possible, should simultaneously advance trade liberalisation and environmental objectives. In doing so, steps should be taken to integrate agricultural and environmenta policies more closely, so that agriculture is conducted on an environmentally more sustainable basis.

Ministers invite the Organisation to continue to support the process of agricultural reform by: monitoring its implementation, including through quantitative instruments and qualitative considerations; improving its capacity to assess the medium-term market outlook; assessing the impact of various policy scenarios for reduction of support and protection on production and trade; analysing particular aspects of the reform process, such as direct income support and structural adjustment, and their effect on incomes and social and environmental conditions, and on economic efficiency, while recognising that in some countries agriculture is multifunctional in character; defining policies which can achieve both agricultural reform and protection of the environment, and which can contribute to an efficient set of policies in the context of rural development; and assessing and promoting ways of maximising the positive impacts of reform on non-member countries and of assisting those countries moving towards a more market-oriented agricultural system, while taking into account the interests of food-importing developing countries.

\section{Rural Development}

Ministers are concerned by lagging economic development in many rural areas. They recognise significant public interest in the environmental, social, recreational and cultural values of these areas. They consider that dynamic rural development policies can help to smooth structural adjustment there. The design and execution of such policies, which address both economic and public-value goals, is a complex task which provides scope for the participation of several ministries at the national level, and roles for authorities at the regional and loca levels as well as for the private sector. Reformed agricultural policy has a significant part to play, as do policies in other domains, the aim being to identify different possible ways for the development of rural areas. Ministers expect that the recently established Rural Development Programme will take a multi-sectoral, inter-disciplinary approach to rural development policy; they look forward to the Programme's report and recommendations in 1992.

\section{Technology}

Ministers note the reports on the Technology/ Economy Programme (TEP). They believe that the findings of the TEP exercise demonstrate vividly the close inter-relationships between a range of issues in areas such as science and technology, human resource development, corporate governance, trade, investment and competition, all of which will increasingly underpin national competitiveness and economic performance in the 1990s, and the need for governments better to co-ordinate and ensure coherence amongst domestic policies in these fields. Ministers underline the role of technology in helping to sustain growth and welfare, both in OECD countries and also in non-member countries. They stress the central role of the firm in the technological process, and underline the important role of governments in providing an economic and social environment conducive to the fostering of this process, both domestically and internationally. They encourage the Organisation to continue actively its monitoring activity on structural and trade aspects of technology-related issues, in particular in respect of communication technologies. Ministers welcome the report of the ad hoc group of the Council on the Technology/Economy Programme and accordingly have agreed to the policy statement annexed to this Communiqué.

\section{Competition}

Competition Policy. The increasing international scope of economic activity has resulted in a situation in which the existing 'rules of the game', as defined by national or regional competition policies, might be usefully complemented. Ministers ask the Organisation to continue its work on the international dimension of competition policies and on their interaction with policies in other areas such as trade and industry. They note that recent work in the Organisation on competition law and policy provides the foundation for greater policy convergence and progress towards updating and strengthening the existing rules and arrangements (including both policy principles and procedures) for international co-operation in this area. They invite the relevant committees actively to pursue these matters, including the effectiveness of trade rules in facilitating international competition.

Industrial subsidies. Ministers re-affirm their

1. Agricultural Policies, Markets and Trade: Monitoring and Outlook 1991, OECD Publications, Paris. 
view that industrial subsidies have generally impeded rather than promoted structural adjustment, have created or sustained inflexibility and distortions, notably in the trade area, and have added to pressure on public expenditure. Ministers remain firmly of the view that every effort should be made to eliminate or bring under enhanced discipline subsidies that have trade distorting effects. Ministers welcome progress by the Organisation in improving transparency in this area, which will strengthen the basis for a common international understanding of the economic effects of industrial subsidies. They invite the Organisation to engage in a systematic monitoring of industrial subsidies, and they commit their governments to providing the information necessary to update and improve the internationally comparable data base which has been constructed under the auspices of the Industry Committee. OECD governments wil step up their collective efforts to increase transparency, in particular through a peer review procedure and, taking into account developments in the Uruguay Round negotiations, to improve industrial subsidy discipline. This work could lead to the eventual definition of commonly accepted OECD guidelines.

Shipbuilding. Ministers welcome the progress made in the OECD Council Working Party on Shipbuilding towards a draft agreement respecting normal competitive conditions in the commercial shipbuilding and repair industry. They welcome that all parties are firmly committed to conclude a balanced agreement, the main elements of which are now taking shape, and emphasise the need to maintain momentum in the negotiation to present a draft agreement by July 1991 , so that outstanding political differences can be resolved as quickly as possible. Ministers also note with satisfaction that the Republic of Korea fully participates in the negotiation.

Export Credits and Tied Aid Credits. Ministers remain convinced of the need for a balanced agreement to reduce substantially, through improved discipline and transparency, the trade and aid distortions that result from the use of subsidised export credits and of tied aid credits. Therefore, they welcome the reports from the Chairmen of the competent OECD bodies and the progress made on the main elements of a future agreement. Against this background, Ministers expressed their commitment to overcome remaining obstacles in order to come to an agreement in the near future; in any case, not later than the end of this year. Ministers welcome the agreement reached in the Export Credit Group of the Trade Committee to study export credit premium systems and structures, and they look forward to a report on its completion.

\section{Financial Matters}

Financial Markets and Foreign Direct Investment. Structural reform has made the greatest progress in areas affecting capital flows and foreign direct investment (FDI), and these have importantly affected the external positions of member countries. Nonetheless, it is still necessary to ensure that liberalisation gains are consolidated and extended, in particular with respect to FDI, in light of a number of signs in recent years in policies and practices that run counter to the liberalisation trend. To this end Ministers adopted the Report on the Review of the 1976 Declaration and Decisions on International Investment and Multinational Enterprises. They welcome the reinforcement of the Declaration, through the addition of a section on co-operation to avoid conflicting requirements on multinational enterprises and the introduction in the Guidelines for Multinational Enterprises of a new chapter on protection of the environment. They note the progress towards a strengthening of the National Treatment Instrument inspired by the principles of standstill, non-discrimination, transparency and rollback, and agree to reinforce the procedures for implementing the existing substantive commitments through notification, examination and a multilateral framework for dealing with conflicts that may arise. They also express their determination further to reinforce and broaden the scope of international discipline in the area of FDI.

The OECD Codes of Liberalisation have played and continue to play an important role in promoting free movements of capital between countries, and have contributed to the maintenance of free current invisible transactions. Ministers welcome the prospect of the extensive further liberalisation of the banking and financial services, agreed in May 1989, entering into effect in the very near future. OECD governments remain firmly committed to the pursuit of continued liberalisation in the field of investment and services. Progress has already been achieved in the areas of tourism, audio-visual works and insurance, as well as in banking and financial services. Efforts to promote liberalisation must be continued through further strengthening of the Codes and investment instruments.

Certain sectors of financial markets have experienced problems in recent years. Ministers note the recent announcement of financialsector reform to modernise the regulatory and prudential framework of financial markets in the United States, with the overall objective of enhancing competition and improving efficiency. They welcome the intention of the US authorities to proceed with these reforms in a manner consistent with the principles of the OECD Codes of Liberalisation. They invite the relevant OECD committees to intensify surveillance of international financial developments, with a view to keeping members informed and promoting both further liberalisation and co-operation among national regulators.

Ministers welcome the significant strengthening of international co-operation, in particular among OECD countries and other participants in the Financial Action Task Force, to stem the use of the financial system in laundering the proceeds of criminal activities, in particular drug and drug-related offences. They agree to develop this co-operation further and invite the Organisation to provide secretariat services to the Task Force.

\section{The Social Field}

In spite of considerable economic progress in OECD countries, concerns remain about a number of societal issues, including long-term unemployment, inequality of opportunities, marginalisation, persistent dependency on income transfers, and demographic developments. Economic progress and success on the social front are mutually supportive. This will require a concerted approach over the longer term in a complex range of policy areas. This includes, in particular, the development of the skills needed fully to exploit the new technologies and the opportunities they present; the need to re-integrate those excluded from activity; and policies to cope with intensifying urban problems and to revitalise declining rural areas. Successful adjustment of our economies and societies will also require renewed efforts to improve opportunities for women in the labour market and to advance their careers throughout working life. To achieve all these goals it will be necessary to reinforce the emphasis on integrated 'active' policies rather than passive income support programmes which often discourage participation. Ministers urge the OECD to step up work in the domains covered in the following paragraphs.

\section{Labour-market Policies}

\section{and Human Resource Development}

Ministers endorse the main conclusions of the meeting of the Education Committee at Ministerial level in November 1990, which emphasised that: high-quality education and training provide the foundation for developing a broad range of skills for all; access, governance, financing and partnership are important for the successful performance of educational systems; and to promote lifelong learning, education has to be complemented by training and re-training, especially for adults. Ministers, concerned about the high levels of unemployment in many countries, encourage active labourmarket policies which will facilitate structural change, for example, through the provision of training for the unemployed and for workers threatened by displacement. Labour-market and social policies will also aim at supporting those who have never entered the labour market or those who have become detached from it, and in particular, those who have become dependent on income transfers. Such labour-market, social, education and training policies are part of a comprehensive approach to human resource development, and will help to meet one of the key challenges of the next ten years: ensuring that labour markets and labour forces can respond flexibly and effectively to growing social and economic change. The approach here will also include local initiatives and enterprise creation, as well as attention to coherence in policy design and implementation between various levels of government and between different programmes and institutions. Policies and programmes will be co-ordinated and developed in partnership with business, trade unions and community-based organisations.

\section{Social Policy}

Social policy will have to respond to concerns about a series of issues which affect the cohesion of the fabric of OECD societies. There 
are moves towards new orientations for a range of social policies based on partnerships involving individual initiative, public intervention, actions by voluntary and community associations and private-sector enterprises. The aim is to improve the responsiveness of social programmes to individual needs; to encourage individuals to become active members of society; and to enhance efficiency in the provision of social services, which should contribute to countering persistent dependency on income transfers and to tackling the rising costs of health and pensions systems. Public policy will contribute to developments in these areas by improving integration and co-ordination amongst policy instruments. Ministers invite the Organisation to undertake work which throws more light on these issues and on the most appropriate responses of social policy.

\section{Migration}

While recognising that immigration has made and can, under appropriate circumstances, continue to make a valuable contribution to the economic and social development of OECD countries, Ministers note the widespread concern that pressures for migration are building up world-wide due to a variety of political, social and economic factors which demand further study. Ministers request the Organisation, in the light of the outcomes of the International Conference on Migration (Rome, 13-15 March) and in co-operation, as appropriate, with interested governments and other international bodies, to intensify its work on assessing and comparing migratory flows and their trends; on assessing the economic and social causes and consequences of migration both for the receiving and for the sending countries, where the lack of development opportunities contributes to migratory pressures; on evaluating possible policy responses to emigration countries; and on the exchange of information on national policies and practices. OECD work on this subject will take into account the importance of humanitarian factors and applicable international agreements.

\section{Urban Affairs}

Problems in urban areas, such as imbalance between demand and supply of urban infrastructure, traffic congestion, scarcity of adequate housing, deterioration of the urban living environment, and poverty are becoming more serious. Ministers invite the OECD to identify solutions in the light of the importance of these urban problems, while taking into account such factors as each country's economic and budgetary situation.

\section{The Environmental Field}

Ministers welcome the results of the Meeting of the OECD Environment Ministers in January 1991, which constitute an important contribution to the evolution of environmental policymaking. Faced with the magnitude of national and regional environment issues and the unprecedented challenge of global environment issues, Ministers agree that OECD countries should pursue an environment strategy for the 1990s based on integrating economic and environ- mental decision-making, improving their environmental performance, and strengthening international co-operation. Ministers agree the need for the Organisation to review more systematically the performance of individual OECD countries in meeting domestic environment objectives and international commitments and they welcome the Environment Ministers' initiative to launch reviews of member countries' environmental policies. As well, Ministers recognise that OECD countries, given their level of development, have a special responsibility to work co-operatively with other countries in other regions to achieve sustainable development.

Ministers welcome the direction and impetus given by the Environment Ministers to strengthening the integration of economic and environment policies as a key to sustainable development. They agree with the principles proposed for working towards this objective: economic and environmental policies cannot be made and implemented in isolation; environmental considerations must be brought to bear systematically on economic policy-making; sound economic analysis of costs and benefits, coupled with scientific assessment of relative risks including that of inaction, is the optimal basis for setting priorities among environmental goals, and compatibility between environmental and sectoral economic policies should be a central objective of policy-makers. Ministers call for improved integration of environment considerations into all economic sectors and for the OECD to continue its work on analysing the policy interconnections. They agree that effective policy integration will require a greater degree of dialogue with and participation from all sectors of society and the economy if environmental goals are to be met effectively and efficiently and to prevent policy conflicts from arising in such areas as agriculture, coastal zone management, energy, and transport and more generally on trade and investment. Ministers also support additional work on 'OECD guidelines' to assist member countries to make more effective and widespread use of economic instruments.

International co-operation is critical to coping successfully with global environmental issues and risks in the 1990s. Many environmental issues, for example, climate change, conservation of living marine and land resources, ozone depletion, deforestation, desertification and loss of biodiversity, highlight the extent of global interdependence not only in terms of the causes of environmental degradation but also in terms of the consequential effects of implementing certain economic or environmental policies. This interdependence, however, also offers the opportunity for new forms of international co-operation amongst $O E C D$ countries on the one hand and with non-member countries on the other. One of the most important elements in this international co-operation is to promote development and transfer of environment-related technologies. In this context, Ministers welcome the establishment of the Global Environment Facility (GEF) and are looking to this programme, as well as to relevant activities of other existing institutions, to contribute to the improvement of the global environment. Ministers also believe the OECD can play an important role in fostering international co-operation and contributing to the solutions. They welcome the OECD/IEA work on emission inventories, policy instruments and economic analysis of policy options as positive contributions to the global climate change negotiations.

The 1992 United Nations Conference on Environment and Development provides a timely opportunity to strengthen international $\mathrm{Co}-$ operation. This event should be used to renew international commitment to sound environmental management, and to seek a consensus on goals and priorities for the 1990s and beyond, as a basis for agreed commitments for concrete action. Ministers give full support to the contribution envisaged by the OECD, including the convening of a meeting of OECD Ministers of Development and Environment in 1991 to consider measures to ensure that development and environmental policies are compatible and reinforcing. Ministers agree that $O E C D$ governments must confront, with new commitments and adequate resources, the pressing issues of resource availability and technology transfer for environmental improvement in developing countries. Ministers underline the role that the GEF could play as the mechanism to provide additional assistance to developing countries in the framework of the ongoing negotiations on the global environment.

Trade and the Environment. Ministers welcome the joint report on trade and environment issues prepared by the Trade and Environment Committees. The report identifies the key interconnections between these important policy areas and makes suggestions on areas in which the analysis should be deepened. Ministers endorse the preliminary views developed by the two Committees on a work programme that will underpin further analyses and could lead, in a subsequent stage, to the drawing up of guidelines on ways to protect the environment and preserve the open multilateral system. They invite the Organisation to pursue this work and call for a report on the progress achieved, on all those elements that have been highlighted, to be made to the 1992 meeting of the Council at Ministerial level, giving also regard to possible contributions to the United Nations Conference on Environment and Development (UNCED) in June 1992.

\section{Public-Sector Management}

In the face of rising pressures on public expenditure and concern about the effectiveness with which the public sector operates to meet its objectives, OECD governments are reviewing its organisation and management, with the particular objectives of increasing the efficiency of the economy, improving the management of human resources, increasing the accountability of public officials and improving the quality of services to the public. They are considering more cost-effective ways of financing and delivering public goods and services. This may provide a different division of responsibilities 
between the public and private sectors, a wider appeal to market mechanisms, or, for instance, in education or social policy, a combination of public- and private-sector responsibility, and individual initiative. In other cases, it would appear necessary to re-appraise the methods of operation of the public authorities, while preserving the specificity of their mission. Ministers also recognise that the increasingly interdisciplinary nature of the issues dealt with by the OECD points to the need for new approaches to public-sector management and to co-ordination among public-sector authorities in member countries.

\section{Energy}

The Gulf crisis and the likelihood of increased dependence of the OECD region on oil imports from the Middle East over the coming years underscore the importance of continued efforts by governments to reduce their vulnerability to oil supply disruptions. As agreed by Energy Ministers, energy security will be further enhanced by a range of measures and policies, which include: improving and timely testing of emergency response mechanisms; maintaining diversified energy supplies, both in terms of fuel and sources; exploiting all economic and environmentally appropriate opportunities to promote energy production world-wide; promoting energy efficiency and conservation; supporting research and development, introduction of new technologies, and further development of competitive markets and liberalised trade. Global environmental issues heighten the importance of pursuing integrated policies which further the objectives of energy security, environmental protection, and economic growth. Action must be taken to address conventional pollutants and greenhouse gas emissions at both the national and international level. In relation to the global climate change issue, detailed study is needed of the technical potential for reducing greenhouse gas emissions as well as the costs and benefits of various measures to mitigate emissions, including economic instruments. As governments develop policies to address environmental issues, in particular global climate change, approaches must be integrated in a manner consistent with the need for diversified energy supplies and unfettered international trade in energy. The successful implementation of energy policies to achieve environmental goals will require industry participation and heightened consumer awareness. The growing convergence of the energy interests of OECD and non-OECD countries is a major facet of the increasing interdependence and globalisation of economic activity. All non-OECD countries can benefit from the energy policy experience of OECD countries. This is particularly true for the Asia-Pacific region and Latin America where energy demand is growing rapidly, and for central and eastern European countries as they move towards market economies. These latter countries and the Soviet Union will benefit from the development of new energy links with the OECD countries, including free and undistorted energy trade. The problems facing the Soviet oil and gas sectors warrant special attention given this country's position as the world's largest oil and gas producer. Contacts among all market participants should be further developed to promote communication and understanding. Such contacts could enhance the efficiency of the market, which is the best allocator of resources and determinant of oil production volumes and prices. Ministers encourage NEA analysis/assessment of nuclear energy in Eastern Europe, in particular as it relates to safety issues, in consultation when appropriate with other specialised agencies such as the IAEA.

\section{Co-operation with Non-member Countries}

Ministers welcome the OECD's steadily strengthening relations with non-member countries, along with the world-wide move towards the common values of OECD countries: pluralist democracy, respect for human rights, and a competitive market economy. These values have proved to be the best possible basis fo long-term economic and social development. They wish to see this strengthening continue, while taking due account of the diversity of nonmember countries' situations, circumstances and policies. Co-operation with non-member countries in all regions and at all levels of development may take a wide variety of forms, the choice of which will be guided by a pragmatic approach. In some cases this could ultimately lead to membership in the Organisation for countries which share common OECD values and characteristics, express interest, and are prepared to accept OECD rules and disciplines. At the same time, Ministers re-affirm their determination to give high priority to co-operating with developing countries.

The Developing Countries. The economic, political and social situations of the developing countries have tended to diverge, with some promising developments, but conditions in many developing countries remain a matter of concern. Difficult structural adjustment and policy reforms have been set in train by a number of developing countries in Asia, Latin America and Africa, and are beginning to bear fruit. But in many other developing countries economic and social conditions have been consistently deteriorating. While effective development depends primarily upon the developing countries themselves implementing appropriate policies, OECD countries have nevertheless to enhance, along the lines described in the 1990 Ministerial Communiqué, their support to these countries, and in particular, to the least developed among them, and to those which are adopting effective policies to meet the challenges they face. This support must aim to assist developing regions to surmount the difficulties they encounter in the adjustment of their economies, but equally to support actively the process of democratisation, respect for human rights and the transition towards competitive market economies which is proceeding in a growing number of developing countries. This co-operative effort with developing countries will focus on policies which integrate the shared objectives of:

- promoting sustainable economic growth and integration in the world economy, particularly of those developing countries which face the prospect of declining participation in it

- reducing excessive military expenditures

- enabling broader participation both by men and by women in productive economic activities and enabling markets and private initiative to play their full role, and encouraging a more equitable sharing of the benefits

- promoting human rights, democratisation, open and accountable government institutions and the rule of law

- ensuring environmental sustainability, and slowing population growth where it is too high for sustainable development

- combating the illicit production, trafficking and consumption of narcotics.

In addition, OECD countries' policies can do much to improve the prospects for developing countries. To this end, Ministers recognise the need for a more coherent policy approach to their co-operation with developing countries to help them overcome their difficulties. Sound macro-economic policies which lead to sustainable non-inflationary growth can contribute importantly to a healthy global economic environment. Open markets provide the developing countries with the maximum opportunity to prosper; hence, in particular, the importance of a successful conclusion of the Uruguay Round. Market transparency is important; exchanges of views and information between producers and consumers of commodities can facilitate it. Cooperative approaches to relieving debt burdens and securing new resources flows in the context of structural adjustment efforts can help significantly, especially in the case of poorer developing countries. Ministers stress the need for continuing action to tackle the debt problems affecting many developing countries, and re-affirm their support for the strengthened debt strategy. They note that the debt problems of the low income countries remain particularly severe, and look forward to an early and appropriate conclusion of the Paris Club's discussions of additional debtrelief measures for the poorest most heavilyindebted countries. They consider also that efforts under way to relieve the debt burden of heavilyindebted lower middle-income developing countries should be pursued in line with the restructuring actions taken in the multilateral framework of the Paris Club. The debt problems of many of these countries should be closely monitored.

Ministers recognise that in view of the huge development tasks ahead, particularly given the strong efforts towards democratisation and economic policy reform throughout the developing world, substantial additional aid efforts will be required both quantitatively and qualitatively. They take note of the target already established by international organisations for the future level of development assistance ( $0.7 \%$ of GNP). They recall that at the recent Conference on Least Developed Countries there was agreement that 'a significant and substantial increase in the aggregate level of external support should be made available' and that 
options for implementation were recommended for various categories of donor countries. The important role that foreign direct investment could play in this field should also be noted. Ministers re-affirm that their determination to give high priority to their co-operation with developing countries will not be diminished because of their support for central and eastern Europe, nor by the developments in the Gulf region.

Ministers emphasise the need for participatory development, including broad-based economic growth and equity, protection of human rights and improvement of governmental effectiveness. An optimal public resources allocation can only be achieved through good governance.

Given the dramatic changes in some parts of the world towards pluralistic democracy, respect for human rights and a competitive market economy, opportunities exist for new approaches to relations between developed and developing countries. Members will continue their work in the relevant OECD bodies to develop these new approaches. Ministers welcome the results of the second United Nations Conference on the Least Developed Countries. The forthcoming Eighth Session of the United Nations Conference on Trade and Development will provide a test of the determination to take further the new consensus on the requirements for effective development progress and a sustainable global economy, based on an effective partnership between developed and developing countries.

Central and Eastern Europe. The changes in central and eastern Europe towards pluralistic democracy are of great historical importance. The complex and difficult process of transition from a centrally-planned economy to a marketbased one, which has begun in central and eastern Europe, is a necessary follow-up to these changes. Ministers welcome this economic reform and encourage the countries concerned to persevere because its success is critical to economic renewal and sustainable growth. It will entail substantial structural adjustments and require deep changes in policies and established patterns of thinking. In the light of this challenge, the OECD countries, and the Organisation as such, should support this process to the fullest extent possible, and promote links with these countries.

International assistance, by actively supporting the reform effort, will also help sustain the political will to reform. Such assistance must involve the co-ordinated efforts of governments and the major multilateral institutions, including the OECD, the recently established EBRD, the IMF, the IBRD, the G-24 process chaired by the EC Commission, the CSCE, the ECE, and the ILO, and be designed to foster market disciplines. Ministers agree on the importance of supporting the transition in these countries toward democratic institutions and marketoriented economies in the most efficient, effective and transparent manner possible. In this respect they endorse a conclusion of the participants in the Arrangement on Guidelines for Officially Supported Export Credits that they would try to avoid tied aid credits other than outright grants, food aid and humanitarian aid, into central and eastern Europe. They agree that the Organisation should keep this matter under active monitoring, with a view towards discussion and resolution of policy issues which may arise.

In view of the breadth and complexity of the problems that have to be addressed, and of the inherently limited and temporary nature of the balance-of-payments assistance made available by the G-24 countries, there is a role for a variety of forms of assistance only some of which involve direct financial support. In particular, access to markets in OECD countries and sustained economic growth in the OECD area can contribute significantly to the success of the reform process. The OECD will keep under active review trade between central and eastern European countries and OECD member countries, with a view towards identifying trade restrictions, thereby facilitating their removal, and towards promoting trade transparency. Ministers look forward to reports on these issues at their 1992 meeting. Private investment has an essential role to play and should be actively encouraged. Ministers re-affirm the shared willingness of their countries to play their fair part in the global international assistance effort. But whatever the size and modalities of this effort, the reforming countries retain the essential role and responsibility in determining the most efficient way for delivering comprehensive reform based on free-market principles.

Ministers endorse fully the role of the OECD in providing technical assistance for policy formulation across a wide range of activities, directed primarily at building up public and private institutions and at developing the human resources needed for a successful transition. This role could still be strengthened. They emphasise the role of the Centre for Co-operation with European Economies in Transition in organising a coherent and comprehensive assistance programme. They particularly stress the importance of the establishing of the Centre's 'Partners in Transition' programmes, designed to provide special assistance and services by the OECD to countries that have demonstrated a resolute commitment to a rapid transition to a market economy and to a pluralistic democracy, and have expressed the wish to entertain special links with the OECD.

Ministers express concern over economic developments in the Soviet Union and their negative implications for world trade, in particula for trade between central and eastern European countries. They recall the message of The Economy of the USSR prepared by the IMF, the IBRD, the OECD and the EBRD on the mandate given by the Houston Economic Summit, that fundamental reform was the only answer to underlying structural problems in the Soviet economy. That message remains valid. They hope that the USSR and the Republics would move quickly to introduce the broad range of macroand micro-economic reforms necessary to move to a market economy, as recommended in the study. They note that policy dialogue, technical assistance, and humanitarian aid can support reform, and consider that, whenever appropriate, existing multilateral institutions should be used to channel assistance. They recognise the special expertise of the OECD and welcome its technical assistance to the Soviet Union, and where appropriate the individual Republics. They call on the Organisation to continue its monitoring of economic policies and reforms in the Soviet Union in the light of the recommendations of the Study and subsequent and ongoing developments. They also welcome the establishment of a regular exchange of information within the Organisation on economic policies toward and relations with the Soviet Union. They encourage the Organisation to continue to pursue appropriate technical contacts with the Soviet Union, drawing on the experience acquired.

Dynamic Asian Economies. The dynamic Asian economies have confirmed their impressive economic performance, albeit at a slightly slower pace than in previous years. Their significant contribution to world economic growth and international trade underlines the need for deepening further the informal dialogue started three years ago. This has led to a better understanding of the OECD/DAE economic relationship; a convergence of views on policy cooperation which in turn will help to foster economic relations between them; and a shared resolve to strengthen the multilateral trading and investment system. In this latter respect, Ministers welcome in particular the ongoing trade policy discussions between the Dynamic Asian Economies and OECD member countries.

Ministers call on the OECD, while taking account of the diversity of DAE aspirations and circumstances, and in close consultation with them, to develop the dialogue further. Ministers hope that it may soon lead to the establishment of closer and more structured links between the Organisation and the DAEs where mutually desired.

Latin America, and in particular Mexico. Those Latin American countries that have en gaged in major market-oriented policy reforms have improved their economic situation and are better placed to play a more active role in the global economy. This holds out the hope that the people of this region will be in a better position to take advantage of its vast economic potential. Mexico, in particular, is carrying out resolute market-oriented policy reforms. Ministers welcome the wish recently expressed by Mexico to broaden its links and co-operate more closely with the OECD. They invite the Secretary-General actively to follow up on this, and to report progress at their meeting in 1992.

$$
\cdots
$$

\section{Yugoslavia}

Ministers recall the long association of Yugoslavia with the work of the Organisation. They express their hope that the conditions necessary for Yugoslavia to continue with its reforms towards a market economy will be improved, so that continued and sustainable economic progress can take place and links with the Organisation be further expanded. 


\section{Ensuring and Sustaining Recovery}

Conditions appear favourable for a resumption of growth in the OECD area, following the sharp slowing during the past year. Ensuring and sustaining this recovery will depend on appropriate actions across the full range of policies. Monetary conditions have been eased in countries where output has weakened most, and automatic fiscal stabilisers have moderated the fall in demand. As this policy stance - together with lower inflation and a return of confidence - brings a turnaround, it will become important to exercise sufficient monetary restraint to avoid economies becoming overheated once again. Meeting medium-term commitments to reduce budget deficits will also be critical in the recovery in order to maintain financial stability and relieve upward pressure on interest rates as demands on saving build up. ${ }^{1}$

Unemployment, which is high and rising in many countries, may not decline much in the coming recovery. Achieving lower rates of unemployment while maintaining price stability, in part by enhancing people's ability to adjust to change, will require the removal of structural obstacles. More generally, continuing structural reforms on a broad front will be required to respond to - and gain the full fruits of - increasing economic and financial integration among OECD countries. Such reforms would also provide a more supportive international economic environment for other regions. The immediate priority is to make rapid progress in the large number of areas covered by the Uruguay Round, including reform of agricultural policies. In addition, policies with respect to industrial subsidies, research and development, foreign direct investment and market competition have to be brought under closer multilateral surveillance in order to increase the transparency of such policies, prevent conflicts arising from incompatible approaches and foster policies conducive to the more efficient use of resources.

\section{The Current Situation and Short-run Growth Prospects}

Economic growth in the OECD area as a whole slowed sharply in the second half of 1990 and virtually ceased in the first half of this year (Table 1). This is the weakest performance since 1982. During the past year, output fell for two or more successive quarters in the United States, United Kingdom, Canada and a few other countries where inflationary pressure had built up and monetary conditions had been tight for some time. Developments in the Gulf were important in tipping these economies into, or further into, recession: the sharp rise of oil prices in the late summer adversely affected both inflation and growth; and with the outbreak of hostilities in January, both businesses and households cut back spending. In most other European economies, which likewise felt the impact of the Gulf crisis, economic growth decelerated somewhat later and less sharply. In Japan and western Germany, where economic activity expanded strongly in 1990, output growth appears to be easing back to more sustainable rates.

The OECD expects a moderate pick-up in the second half of this year, led by upturns in some of those countries now in recession, in particular the United States. Growth is also expected to recover in those countries where it has virtually stalled recently, while the extent of the slowdown in Japan and Germany ${ }^{2}$ should be limited. This assessment is based on the following considerations:

- the rebound of confidence following the end of the Gulf war has reversed an important factor intensifying the weakening of economic activity - interest rates have fallen in many countries; declines have been largest in short-term interest rates in countries experiencing recession

- grounds for concern about inflation over the short term have been reduced - the reversal of earlier oil-price rises has fed through to consumer and retail prices, while the opening up of employment and output gaps is relieving the upward pressure on wages and prices that had been evident a year ago

- although governments have continued to focus on medium-term fiscal objectives and have not sought to boost demand by spending more or by cutting taxes, most have allowed automatic stabilisers to moderate cyclical demand weak ness

- firms have generally been able to prevent a build-up of unwanted inventories despite the weakness of activity; a pick-up of final demand should therefore translate quickly into higher output.

Most importantly perhaps, fundamental conditions have not weakened from those that sustained eight years of expansion through last summer. Indeed, three important macro-economic conditions for stability and confidence have been reinforced: the credibility of monetary policies was enhanced by non-accommodation in the face of a build-up of inflationary pressures at the end of the 1980s; there is renewed emphasis on medium-term fiscal control in countries where this had been lax; and the current-account imbalances of the three largest OECD economies have narrowed.

\section{Inflation and Monetary Policy with Renewed Growth}

Pressure on capacity has eased over the past year; gaps are beginning to appear between actual and sustainable levels of employment and output. Given that the pace of economic expansion in virtually all OECD economies is likely to be slower than the growth of potential, on average, over the projection period, these gaps could widen between now and the end of 1992. This should be conducive to initiating and sustaining a process of disinflation. But gaps are likely to be small in most countries, so that only a gradual dissipation of overall OECD wage and price momentum can be expected (Table 2).

The margin for error on the side of monetary ease without accelerating inflation thus appears

1. OECD Economic Outlook, No. 49, OECD Publications, Paris, 1991

2. For Germany, all references and projections here in both text and tables, with the exception of current balances, are to western Germany only. 
less now than it was in the early 1980 s, even though inflation rates are generally lower now. In most countries, margins of slack are also no wider than they were following the global stock market plunge in October 1987, when there was a risk of a sharp contraction of liquidity and demand. In retrospect, the monetary policy response to that risk went too far, thereby contributing to the inflationary pressures that began to re-emerge a year later. This would suggest caution in the present situation, and in particular ensuring that easier monetary conditions are not maintained after recoveries are underway. Careful judgement will be required because turning points in output typically are not clearly discernible for some time after they have occurred.

In some countries, particularly the United States, the problem of gauging appropriate monetary conditions has been made more difficult by financial strains. There had been concern that US monetary conditions were tighter than realised or intended because banks, seeking to improve their balance sheets, would be unable or unwilling to provide the credit necessary to sustain economic activity. Although some depository institutions are struggling to restore profitability and to meet prudential capital standards, the growth of other financial intermediaries and securitised finance has rendered these difficulties less important from a macroeconomic standpoint than they would have been a decade or so ago. Thus it now seems that the risk of a US credit squeeze is manageable by the Federal Reserve through normal monetary policy operations. There have also been concerns about impaired credit-worthiness of borrowers, which could hinder a recovery in the United States and elsewhere. However, non-financial businesses and households do not now appear significantly more financially constrained than in earlier comparable periods of demand weakness. Business failures do not seem unduly high and, for households, the value of assets has grown along with indebtedness, leaving net wealth positions not very different overall from what they were at the start of the recovery in the early 1980 s.

\section{Unemployment}

Average unemployment in the OECD area did not fall below $6 \%$ in the 1980 s despite the sustained expansion through most of the decade; for the European Community, the unemployment rate remained over $8 \%$ (Table 3). During the present slowdown, OECD unemployment is projected to rise by 1 percentage point - an additional 4 million people will be seeking work. Sharp increases in unemployment have already occurred in the countries in recession. The projected moderate recovery would probably be
Table 1

\section{GROWTH OF REAL GNP/GDP IN THE OECD AREA ${ }^{1}$}

seasonally adjusted at annual rates (\%)

\begin{tabular}{|c|c|c|c|c|c|c|c|c|c|c|}
\hline & \multirow{3}{*}{$\begin{array}{c}\text { Share in } \\
\text { total } \\
\text { OECD } \\
1987\end{array}$} & \multicolumn{4}{|c|}{ change from previous year } & \multicolumn{5}{|c|}{ change from previous half-year } \\
\hline & & \multirow{2}{*}{1989} & \multirow{2}{*}{1990} & \multirow{2}{*}{1991} & \multirow{2}{*}{1992} & \multirow{2}{*}{$\begin{array}{c}1990 \\
\text { II }\end{array}$} & \multicolumn{2}{|c|}{1991} & \multicolumn{2}{|c|}{1992} \\
\hline & & & & & & & & II & 1 & II \\
\hline United States & 35.9 & 2.5 & 0.9 & -0.2 & 3.1 & 0.3 & -1.8 & 2.7 & 3.3 & 3.3 \\
\hline Japan & 19.3 & 4.7 & 5.6 & 3.5 & 3.5 & 4.2 & 3.3 & 3.2 & 3.5 & 3.8 \\
\hline Germany & 8.9 & 3.8 & 4.5 & 2.8 & 2.2 & 4.5 & 2.4 & 1.8 & 2.1 & 2.8 \\
\hline France & 7.1 & 3.9 & 2.8 & 1.4 & 2.7 & 2.0 & 0.6 & 2.6 & 2.7 & 2.9 \\
\hline Italy & 6.0 & 3.0 & 2.0 & 1.7 & 2.7 & 1.0 & 1.6 & 2.4 & 2.7 & 3.0 \\
\hline United Kingdom & 5.5 & 1.9 & 0.6 & -1.8 & 1.6 & -3.6 & -2.0 & 0.3 & 1.9 & 2.4 \\
\hline Canada & 3.3 & 3.0 & 0.9 & -1.0 & 3.1 & -1.9 & -2.0 & 2.1 & 3.3 & 3.5 \\
\hline Total of above countries & 85.8 & 3.3 & 2.6 & 1.1 & 3.0 & 1.5 & 0.2 & 2.5 & 3.0 & 3.2 \\
\hline Other OECD countries ${ }^{2}$ & 14.2 & 3.5 & 2.8 & 1.5 & 2.3 & 1.6 & 1.4 & 1.6 & 2.5 & 2.7 \\
\hline Total OECD & 100.0 & 3.3 & 2.6 & 1.1 & 2.9 & 1.5 & 0.3 & 2.4 & 3.0 & 3.2 \\
\hline Four major European countries & 27.4 & 3.3 & 2.7 & 1.3 & 2.3 & 1.5 & 0.9 & 1.8 & 2.3 & 2.8 \\
\hline OECD Europe & 39.7 & 3.3 & 2.8 & 1.4 & 2.4 & 1.7 & 1.0 & 1.8 & 2.4 & 2.8 \\
\hline EC & 34.2 & 3.4 & 2.8 & 1.5 & 2.4 & 1.7 & 1.1 & 1.9 & 2.4 & 2.8 \\
\hline $\begin{array}{l}\text { Total OECD less } \\
\text { the United States }\end{array}$ & 64.1 & 3.8 & 3.5 & 1.9 & 2.7 & 2.1 & 1.6 & 2.2 & 2.8 & 3.1 \\
\hline Industrial production: & & & & & & & & & & \\
\hline Major seven countries & - & 4.1 & 1.9 & -0.2 & 3.8 & 2.7 & -3.0 & 3.0 & 4.0 & 4.1 \\
\hline Total OECD & - & 4.0 & 2.0 & 0.1 & 3.7 & 2.5 & -2.4 & 2.9 & 3.9 & 4.0 \\
\hline
\end{tabular}

sufficient to stabilise the rate of unemployment, but not bring it down; at the end of 1992 the unemployment rate in the OECD area could still stand at $7 \%$. But there would seem to be little scope for unemployment rates to come down much without stoking inflation, unless significant further progress is made with structural reforms to improve the functioning of labour markets.

The causes of labour-market failure, although almost certainly different from country to country, have been resistant to correction in many cases. Yet several countries, with very different labour-market institutions, have recorded sustained low unemployment or generated rapid and sustained growth of jobs. Consequently, there is reason to believe that high structural unemployment can be alleviated. A renewed effort is needed to identify and remove impediments to higher employment, and to put in place the necessary mechanisms to enhance job growth. Among other things, this will involve a shift in the orientation of labour-market policies and programmes toward those which encourage and facilitate access to employment - and away from those that induce long-run dependency on benefits, that artificially discourage labour turnover, or that support wage-bargaining processes in which real wages are pushed up to the point where they limit the growth of jobs. Improving labour markets and outcomes will

\begin{tabular}{|c|c|c|c|c|c|}
\hline & \multirow{2}{*}{$\begin{array}{c}\text { Share in } \\
\text { total } \\
\text { OECD } \\
1987\end{array}$} & \multicolumn{4}{|c|}{$\%$ change from previous year } \\
\hline & & 1989 & 1990 & 1991 & 1992 \\
\hline Austria & 0.9 & 4.0 & 4.6 & 2.9 & 3.0 \\
\hline Belgium & 1.1 & 4.0 & 3.5 & 1.9 & 2.3 \\
\hline Denmark & 0.8 & 1.1 & 1.6 & 1.1 & 2.1 \\
\hline Finland & 0.7 & 5.2 & 0 & -2.4 & 0.9 \\
\hline Greece & 0.4 & 2.8 & 0.1 & 0.3 & 1.4 \\
\hline Iceland & 0 & -2.9 & 0.1 & 1.0 & 3.8 \\
\hline Ireland & 0.2 & 5.0 & 5.7 & 2.2 & 2.5 \\
\hline Luxembourg & 0 & 6.1 & 2.6 & 2.9 & 3.4 \\
\hline Netherlands & 1.7 & 4.0 & 3.5 & 2.1 & 2.3 \\
\hline Norway & 0.7 & 0.4 & 1.8 & 2.6 & 3.1 \\
\hline Portugal & 0.3 & 5.4 & 4.4 & 3.4 & 3.4 \\
\hline Spain & 2.3 & 4.8 & 3.7 & 2.9 & 3.3 \\
\hline Sweden & 1.3 & 2.1 & 0.3 & -0.9 & 0.4 \\
\hline Switzerland & 1.4 & 3.5 & 2.6 & 1.2 & 1.7 \\
\hline Turkey & 0.5 & 1.6 & 9.2 & 3.7 & 5.9 \\
\hline \multicolumn{5}{|l|}{ Total of above } & 2.4 \\
\hline Australia & 1.6 & 4.6 & 1.5 & 0.2 & 1.8 \\
\hline New Zealand & 0.3 & 0.2 & 1.2 & -0.4 & 1.0 \\
\hline $\begin{array}{l}\text { Total of above } \\
17 \text { countries }\end{array}$ & 14.2 & 3.5 & 2.8 & 1.5 & 2.3 \\
\hline $\begin{array}{l}\text { 1. Aggregates were } \\
\text { exporessed in } 1987 \text {. } \\
\text { 2. Hall-yearly data m }\end{array}$ & $\begin{array}{l}\text { puted on th } \\
\text { slars. } \\
\text { be interpret: }\end{array}$ & . & e. & & \\
\hline
\end{tabular}


Table 2

PRIVATE CONSUMPTION DEFLATORS IN THE OECD AREA ${ }^{1}$

percentage changes; seasonally adjusted at annual rates

\begin{tabular}{|c|c|c|c|c|c|c|c|c|c|}
\hline & & & & & 1990 & & & & \\
\hline & 1989 & 1990 & 1991 & 1992 & $\|$ & 1 & II & 1 & II \\
\hline United States & 4.5 & 5.0 & 4.3 & 3.9 & 5.3 & 4.0 & 3.8 & 4.0 & 4.0 \\
\hline Japan & 1.8 & 2.4 & 2.5 & 2.1 & 2.3 & 2.8 & 2.0 & 2.1 & 2.1 \\
\hline Germany & 3.0 & 2.5 & 3.3 & 4.0 & 4.1 & 2.0 & 5.2 & 3.7 & 3.4 \\
\hline France & 3.4 & 3.0 & 3.1 & 3.0 & 3.6 & 2.8 & 3.1 & 3.0 & 2.9 \\
\hline Italy & 6.3 & 6.2 & 6.4 & 5.5 & 6.3 & 7.2 & 5.0 & 5.6 & 5.6 \\
\hline United Kingdom & 5.6 & 4.8 & 6.0 & 4.5 & 5.0 & 6.8 & 5.3 & 4.4 & 4.0 \\
\hline Canada & 4.7 & 4.2 & 5.8 & 3.4 & 4.2 & 7.7 & 3.8 & 3.5 & 3.0 \\
\hline Total of above countries & 3.9 & 4.1 & 4.0 & 3.6 & 4.4 & 4.0 & 3.7 & 3.6 & 3.5 \\
\hline Other OECD countries ${ }^{2}$ & 7.8 & 7.9 & 7.5 & 6.4 & 8.1 & 7.4 & 7.1 & 6.4 & 5.8 \\
\hline Total OECD & 4.4 & 4.6 & 4.5 & 4.0 & 4.9 & 4.5 & 4.1 & 4.0 & 3.8 \\
\hline Four major European countries & 4.3 & 3.9 & 4.5 & 4.2 & 4.6 & 4.3 & 4.6 & 4.1 & 3.9 \\
\hline OECD Europe & 5.5 & 5.2 & 5.6 & 5.0 & 5.8 & 5.4 & 5.6 & 4.9 & 4.6 \\
\hline EC & 4.6 & 4.2 & 4.6 & 4.3 & 4.8 & 4.4 & 4.7 & 4.2 & 4.1 \\
\hline Total OECD less the United States & 4.3 & 4.3 & 4.6 & 4.0 & 4.7 & 4.7 & 4.3 & 4.0 & 3.7 \\
\hline
\end{tabular}

\begin{tabular}{|c|c|c|c|c|}
\hline & 1989 & 1990 & 1991 & 1992 \\
\hline Austria & 2.7 & 3.1 & 3.8 & 4.0 \\
\hline Belgium & 3.4 & 3.5 & 3.3 & 3.4 \\
\hline Denmark & 5.1 & 2.6 & 2.8 & 3.1 \\
\hline Finland & 4.8 & 5.9 & 5.2 & 4.1 \\
\hline Greece & 14.8 & 20.0 & 17.8 & 13.2 \\
\hline Iceland & 21.1 & 12.8 & 6.1 & 8.8 \\
\hline Ireland & 3.9 & 3.2 & 3.0 & 2.7 \\
\hline Luxembourg & 3.4 & 3.7 & 3.4 & 3.4 \\
\hline Netherlands & 2.1 & 2.5 & 2.7 & 3.5 \\
\hline Norway & 4.2 & 4.3 & 3.8 & 4.5 \\
\hline Portugal & 13.0 & 13.4 & 11.7 & 10.7 \\
\hline Spain & 6.7 & 6.7 & 6.1 & 5.5 \\
\hline Sweden & 7.2 & 9.3 & 9.5 & 3.8 \\
\hline Switzerland & 3.7 & 5.4 & 4.8 & 3.6 \\
\hline Turkey & 68.7 & 60.3 & 64.0 & 56.0 \\
\hline Total of above countries & 8.0 & 8.1 & 8.0 & 6.8 \\
\hline Australia & 6.7 & 6.1 & 4.2 & 4.0 \\
\hline New Zealand & 6.3 & 6.1 & 4.0 & 3.0 \\
\hline $\begin{array}{l}\text { Total of above } \\
17 \text { countries }\end{array}$ & 7.8 & 7.9 & 7.5 & 6.4 \\
\hline $\begin{array}{l}\text { 1. Aggregates were computed } \\
\text { expressed in } 1987 \text { US dollars. } \\
\text { 2. Hall-yearly data must be inte }\end{array}$ & $\begin{array}{l}\text { the bas } \\
\text { eted } w\end{array}$ & $\begin{array}{l}\text { of } 198 \text {. } \\
\text { are. }\end{array}$ & & \\
\hline
\end{tabular}

also require renewed attention to the need for remedial or further education and training of large sections of the labour force whose skills are inadequate or becoming obsolete. Structural reforms of a wider nature could also contribute to lower structural unemployment - for example, correcting housing policies that have the effect of impeding mobility.

\section{External Considerations}

The current account surpluses and deficits shown in the projections are not grounds for major concern. The long-standing imbalances of the three largest countries have been substantially reduced (Table 4 ).
External considerations nonetheless matter for policy choices - most directly with respect to exchange rates. Shifts in the values of the dollar, yen and DM (along with other EMS currencies) have been large over recent months: the DM and other European currencies fell off sharply, after reaching new highs against the dollar and showing strength against the yen at the turn of the year. The yen also lost ground against the dollar. Such exchange-rate movements carry a risk that the medium-term process of adjustment of the US trade balance may stall or even be reversed through a deterioration of US competitiveness. Such a development - or, indeed, even perceptions of business that there is a significant risk of a large loss of international cost and price competitiveness through exchange rate appreciation could discourage trade-oriented investment in the United States. To date, exchange rates have not moved so far as to be a serious cause for concern in this respect. Co-ordination of exchange-market operations among the major countries, in a context of agreed objectives, which are consistent with underlying policy settings and clear to markets, can improve the prospects for keeping exchange-rate swings from becoming a significant problem.

Within the EMS, it was feared that monetary policy tensions would arise as demand pressures diverged across participating countries and the DM rose against the dollar late last year. But such tensions did not occur. German some narrowing of interest-rate differentials with other EMS currencies. Nevertheless, the risk that such tensions could re-appear underscores the importance of continuing to reinforce the integration of markets for goods and services, both within the European Community and more widely. This would allow excess demand or supply in one country to be quickly absorbed within a larger market, thereby reducmonetary tightening has been accompanied by ing disparities that might otherwise give rise to pressures that could result in differentiated monetary conditions across EMS countries.

\section{Medium-term Fiscal Objectives}

Over the past year or so, there have been some setbacks to medium-term fiscal consolidation. In the United States, the budget deficit was pushed up by the cost of financing the Resolution Trust Corporation (RTC), set up to deal with the losses of failed thrift institutions, as well as by a substantial expansion of expenditure on medical care. In Germany, the budgetary costs arising from unification have significantly enlarged the deficit. And in most countries, weakening economic activity has slowed fiscal adjustment.

While the German government has some capacity to face large budget-deficit increases as a result of earlier, sustained efforts to contain expenditures and deficits, it is recognised that policy should aim to get back progressively to earlier budget norms. More generally, it is a widespread view, endorsed by governments of OECD countries, that the prospective tightness of global saving makes it all the more important to reduce government claims on saving throughout the OECD area. The continuation of large deficits in the United States, Italy and Canada suggests the need to follow through on a more sustained basis than in the past to achieve stated objectives.

The medium-term orientation adopted by member countries implies that tax and expenditure programmes should not be altered in response to short-term fluctuations of the economy - that is, automatic stabilisers should be allowed to work as a general rule, provided appropriate fiscal outcomes are achieved when averaged over several years. Offsetting the influences of short-term, cyclical fluctuations on the budget deficit would expose businesses and households to increased uncertainty with respect to tax rates and income, as well as removing one of the mechanisms that damp fluctuations in economic activity. But some governments have taken additional discretionary action to contain a cyclical widening of the deficit because of the worry that failure to meet announced budget objectives, even if attributable to temporary demand weakness, could undermine the credibility of the medium-term policy. There are legitimate reasons for such actions, especially where government debt is both high and rising as a share of GNP. Ideally, governments need to establish a course of budgetdeficit reduction that provides some leeway for unexpected developments, and allows for a margin of uncertainty about the sustainable pace of economic growth - overestimates of this pace led to budget-deficit problems in many countries in the second half of the 1970 s and again in the United States in the 1980s. In countries where budget-deficit reduction had been modest under favourable conditions, it may be necessary, when growth slows, to take 
discretionary steps to keep the deficit under control so as to maintain confidence in the medium-term course.

The RTC experience in the United States calls attention to another problem of government finance of concern in almost all OECD countries: the widespread expansion of financial guarantees and off-budget liabilities. Special credits to business, financial guarantees, and substantial export-credit guarantees expose governments to large contingent liabilities. As with the US deposit insurance system, the possible future costs of these programmes are not immediately visible, and reliance on past loss rates to predict future losses can result in unpleasant surprises. Thus there are grounds for concern that budgets may not be under as firm control as suggested by debt and deficit figures alone.

\section{Structural Issues: the International Dimension}

A major task for the 1990s will be to ensure that international trade is carried out in an open and competitive system - a crucial condition for sustained economic growth and employment creation. Two related principles form the basis for actions to maintain and strengthen the open multilateral trading system: first, the principle of non-discrimination in international transactions; and second, that competitive processes should be allowed to determine market outcomes.

The immediate priority remains the Uruguay Round. It is essential to achieve rapid progress over the coming months in the large number of fields covered in the Round. It is important that OECD governments in particular should demonstrate their capacity to act in accordance with their acknowledged interests and responsibilities and their often-repeated intentions.

Of decisive importance for the GATT negotiations is the process of reforming agriculture, for which there are also compelling domestic arguments. Here almost no progress has been made in implementing the reform principles adopted by OECD Ministers in 1987. Total transfers from taxpayers and consumers to agricultural support are estimated to have reached a record level of $\$ 300$ billion in 1990 . $^{3}$ Unless agricultural policies are improved, the related budgetary, economic and trade problems are likely to become more acute.

More generally, the existing framework for international trade does not fully cover the whole range of structural issues which arise out of the interconnections between trade policy and the increasingly international scope of competition, investment, technology and innovation, and environmental spillovers. Hence, widening the focus of trade policies in the 1990s will go hand in hand with a strengthening of the international elements in other policy spheres, including an enhancement of international co-operation across these areas.

OECD member governments have expressed
Table 3

\section{UNEMPLOYMENT IN THE OECD AREA}

national definitions

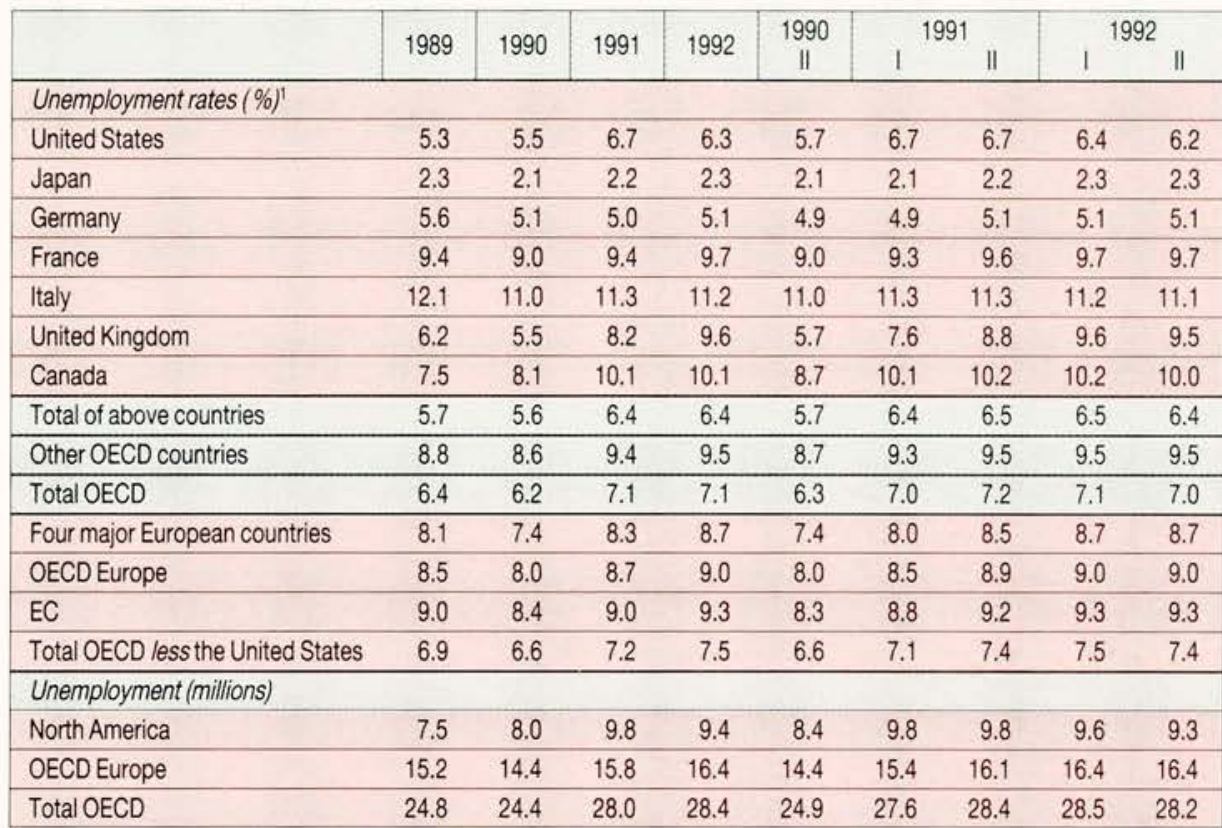

their intention of making the process of multilateral surveillance of structural reform operationally more effective. An important aspect of improving effectiveness here will be the readiness of governments to increase the transparency of support policies in industry, not least those in the form of non-tariff trade distortions, and to make commitments to their reduction.

Policies to support 'strategic' technologies are a source of increasing international friction, while their effectiveness is often questionable. There is a need to develop appropriate guidelines for government support to R\&D, including observance of the principle of national treatment and non-exclusion.

Foreign direct investment is an important vehicle for access to, and diffusion of, technological innovation. Tensions in this area continue to arise from asymmetry of access and issues of reciprocity. Despite considerable progress, there is further scope for reducing divergence in financial-market and other regulations with a view to easing frictions over foreign direct investment policy, and in particular to ensuring that foreign-controlled enterprises are treated no less favourably than domestic enterprises in like situations.

Attention has to be given to the international compatibility of national competition laws in order to maintain and improve competitive conditions on world markets. This is particularly so for policies with respect to mergers and alliances, and their enforcement. Indeed, the need for minimum compatibility has already been recognised within the European Community.

There is growing awareness that many environmental problems are global in nature and

\begin{tabular}{|lrrrr|}
\hline$\%$ & 1989 & 1990 & 1991 & 1992 \\
\hline Austria & 3.2 & 3.3 & 3.5 & 3.8 \\
\hline Belgium & 9.3 & 8.8 & 8.8 & 8.9 \\
\hline Denmark & 9.3 & 9.6 & 9.8 & 9.2 \\
\hline Finland & 3.5 & 3.4 & 5.9 & 6.9 \\
\hline Greece & 7.5 & 7.7 & 9.0 & 10.0 \\
\hline Iceland & 1.7 & 1.7 & 2.1 & 1.8 \\
\hline Ireland & 15.6 & 14.0 & 14.7 & 15.1 \\
\hline Luxembourg & 1.4 & 1.3 & 1.4 & 1.5 \\
\hline Netherlands & 7.4 & 6.5 & 6.5 & 6.4 \\
\hline Norway & 4.9 & 5.2 & 5.1 & 4.5 \\
\hline Portugal & 5.0 & 4.6 & 4.5 & 4.6 \\
\hline Spain & 17.3 & 16.2 & 15.9 & 15.6 \\
\hline Sweden & 1.4 & 1.5 & 2.8 & 3.6 \\
\hline Switzerland & 0.6 & 0.6 & 1.1 & 1.2 \\
\hline Turkey & 10.2 & 10.1 & 11.1 & 11.4 \\
\hline Total of above & & & & \\
countries & 9.2 & 8.8 & 9.3 & 9.5 \\
\hline Australia & 6.1 & 6.9 & 9.9 & 9.9 \\
\hline New Zealand & 7.1 & 7.8 & 9.3 & 10.0 \\
\hline Total of above & & & & \\
\hline 17 countries & 8.8 & 8.6 & 9.4 & 9.5 \\
\hline
\end{tabular}

As percentage of labour force

that their solutions will therefore require international action. And, since action by OECD countries alone will not secure the necessary outcomes, the active participation of non-member economies in forthcoming international agreements must be secured. Links between trade and environmental policies are also re-

3. Agricultural Policies, Markets and Trade: Monitoring and Outlook 1991. OECD Publications, Paris, 1991 
Table 4

\section{CURRENT BALANCES OF OECD COUNTRIES}

$\$$ billion; seasonally adjusted at annual rates

\begin{tabular}{|l|r|r|r|r|r|rrr|r|}
\hline & 1989 & 1990 & 1991 & 1992 & $\begin{array}{c}1990 \\
\|\end{array}$ & \multicolumn{1}{|c|}{1991} & \multicolumn{2}{|c|}{1992} \\
\hline United States & -110.0 & -99.3 & -9 & -58 & -108.5 & 19 & -36 & -57 & -58 \\
\hline Japan & 57.2 & 35.8 & 41 & 52 & 28.3 & 32 & 50 & 52 & 52 \\
\hline Germany & 57.2 & 47.9 & 0 & 11 & 39.9 & -4 & 4 & 8 & 14 \\
\hline France & -4.6 & -7.8 & -10 & -10 & -13.8 & -9 & -11 & -11 & -9 \\
\hline Italy & -10.6 & -14.4 & -13 & -12 & -14.0 & -13 & -13 & -12 & -12 \\
\hline United Kingdom & -32.6 & -22.7 & -11 & -12 & -13.1 & -11 & -10 & -11 & -13 \\
\hline Canada & -14.1 & -13.7 & -10 & -9 & -11.9 & -10 & -10 & -10 & -9 \\
\hline Total of above countries & -57.5 & -74.3 & -12 & -38 & -93.1 & 2 & -26 & -42 & -35 \\
\hline Other OECD countries & -20.9 & -19.2 & -14 & -9 & -5.0 & -16 & -12 & -10 & -7 \\
\hline Total OECD & -78.3 & -93.5 & -26 & -47 & -98.1 & -13 & -38 & -52 & -42 \\
\hline Four major European countries & 9.5 & 2.9 & -34 & -23 & -1.0 & -38 & -30 & -26 & -20 \\
\hline OECD Europe & 7.3 & -0.9 & -34 & -17 & 8.4 & -40 & -29 & -22 & -12 \\
\hline EC & 7.3 & 0.9 & -38 & -23 & 2.3 & -43 & -33 & -27 & -18 \\
\hline Total OECD less the United States & 31.7 & 5.8 & -17 & 11 & 10.4 & -32 & -2 & 5 & 16 \\
\hline
\end{tabular}

\begin{tabular}{|lrrrr|}
\hline & 1989 & 1990 & 1991 & 1992 \\
\hline Austria & 0.2 & \multicolumn{1}{c}{0} & 0.1 & 0.1 \\
\hline Belgium-Luxembourg & 3.6 & 4.4 & 3.8 & 5.9 \\
\hline Denmark & -0.9 & 1.6 & 1.2 & 1.5 \\
\hline Finland & -5.5 & -6.7 & -5.5 & -5.2 \\
\hline Greece & -2.6 & -3.6 & -3.1 & -2.3 \\
\hline Iceland & -0.1 & -0.2 & -0.2 & -0.3 \\
\hline Ireland & 0.5 & 1.1 & 0.4 & 0.2 \\
\hline Netherlands & 7.9 & 10.5 & 10.2 & 12.4 \\
\hline Norway & 0.2 & 3.8 & 4.9 & 4.8 \\
\hline Portugal & 0.2 & -0.1 & -0.8 & -1.2 \\
\hline Spain & -10.9 & -16.0 & -15.6 & -16.0 \\
\hline Sweden & -3.3 & -5.8 & -5.5 & -5.2 \\
\hline Switzerland & 7.5 & 9.7 & 12.4 & 13.4 \\
\hline Turkey & 1.0 & -2.6 & -2.6 & -2.4 \\
\hline Total of above & & & & \\
\hline countries & -2.2 & -3.8 & -0.3 & 5.8 \\
\hline Australia & -17.3 & -14.3 & -12.3 & -13.6 \\
\hline New Zealand & -1.3 & -1.1 & -1.3 & -1.1 \\
\hline Total of above & & & & \\
17 countries & -20.9 & -19.2 & -14.0 & -8.9 \\
\hline
\end{tabular}

ceiving increased attention. In this area, the aim should be to ensure that environmental concerns are not used as an excuse for protectionist policies and that trade-policy concerns are not cited as grounds for inappropriate moves in respect of environmental policies.

\section{Social Problems and Policies}

By the beginning of the 1990 s, average real income per head in the OECD area was broadly $25 \%$ higher than it had been ten years earlier. The coming decade could well bring a comparable advance, and indeed there is clear scope for economic policies to improve on past performance. At the same time, concerns remain about the persistence of a number of social problems and the possible emergence of others.
Although continuing economic progress will have positive effects here as elsewhere, these problems need to be directly addressed.

The main problem areas include long-term unemployment; educational failure; poverty and deprivation in particular social groups; urban and rural decay; population aging; and international migration. It will be evident that these are complex and in some cases interrelated phenomena; that in some cases both causes and ways of influencing them are not well understood; and that in the case of migration, and even perhaps of aging, there are potential social benefits as well as costs. Addressing these In some aspects, the design of policies can be viewed as a technical matter, involving (for example) the reform of social transfer systems so as to establish a better trade-off between relieving poverty and creating a culture of dependence on public support, or to make more effective provision for the coming change in the age-distribution of the population. But there are also more fundamental matters at stake, which concern perceptions of what is just and affordable.

Migration across national borders deserves specific mention, since it is clearly emerging as a major issue for the OECD countries. There are strong and increasing pressures which arise from the higher prosperity and wider opportunities that OECD economies offer, together with the low cost of movement and - for some countries, particularly in central and eastern Europe - more freedom to emigrate. Experience over the centuries has shown that immigrants have been an appreciable source of strength for host countries, an experience that has been validated by the role that immigrant labour played in the economic performance of OECD countries in the 1950s and '60s. But the dimensions that immigration is now reaching - or could reach - are beginning to pose difficult problems will require a careful blend of policies. problems in some member countries. Thus OECD governments have to consider whether and how better to control and programme such immigration, and how best to integrate immigrants into the labour force and society. At the same time, economic and demographic imbalances exert considerable emigration pressures and should underline the need to support further development outside the OECD area, most immediately and effectively through more liberal trade policies.

\section{Relations with \\ Non-member Countries}

The trend towards global economic integration, most strikingly underscored by the emergence of Dynamic Asian Economies in the 1980 s as leading exporters and participants in international finance, has been reinforced by several recent developments. Most spectacular have been the moves by central and eastern European countries to establish market-based economies, following the failure of central planning. Another notable development has been the shift in many Latin American countries, from relatively inward-looking to much more tradeoriented strategies. This is underlined by the proliferation of initiatives in the area to set up arrangements for freeing trade, and by the interest of Mexico in taking part in an enlarged free trade area in North America. In many developing countries, a larger role is being accorded to the private sector, with increasing reliance on competitive markets to guide economic activity.

Against this background, both OECD and non-OECD countries have placed increasing emphasis on strengthening relations with each other; the process of adaptation is likely to continue for the foreseeable future. Within it, the two groups of countries have complementary roles and responsibilities for promoting economic development. Developing countries and those in transition from central planning have the primary stake in, and responsibility for, the success of their economic policies. The challenge they face is to build up a political, economic and social infrastructure conducive to the growth of productive investment and domestic saving. OECD countries must provide open market access, as well as anchoring the world economic system with sustained growth, low inflation and adequate domestic saving.

The process of reform and development might also be facilitated by stepping up assistance both technical and financial. As far as official assistance is concerned, OECD governments should ensure that it contributes to the process of reform and development rather than weakening it. Private investment, which brings both financing and technical know-how, can play a critical role if the basic conditions for a competitive market economy - both macro-economic and structural - are put into place.

17 June 1991 